
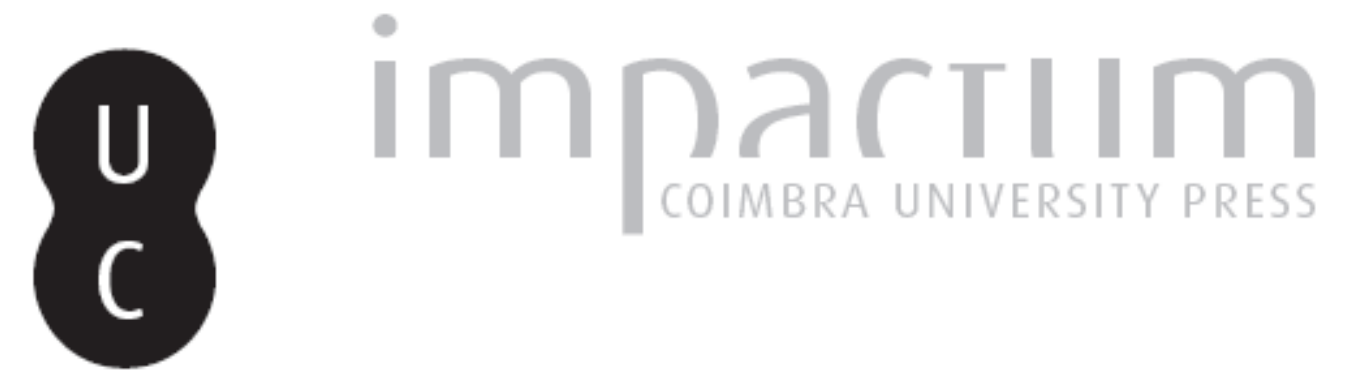

\title{
Em torno do idealismo histórico-social de António Sérgio
}

Autor(es): Magalhães-Vilhena, Vasco de

Publicado por: Imprensa da Universidade de Coimbra

URL persistente:

URI:http://hdl.handle.net/10316.2/45044

DOI:

DOI:https://doi.org/10.14195/2183-8925_5-1_5

Accessed : $\quad$ 26-Apr-2023 06:53:08

A navegação consulta e descarregamento dos títulos inseridos nas Bibliotecas Digitais UC Digitalis, UC Pombalina e UC Impactum, pressupõem a aceitação plena e sem reservas dos Termos e Condições de Uso destas Bibliotecas Digitais, disponíveis em https://digitalis.uc.pt/pt-pt/termos.

Conforme exposto nos referidos Termos e Condições de Uso, o descarregamento de títulos de acesso restrito requer uma licença válida de autorização devendo o utilizador aceder ao(s) documento(s) a partir de um endereço de IP da instituição detentora da supramencionada licença.

Ao utilizador é apenas permitido o descarregamento para uso pessoal, pelo que o emprego do(s) título(s) descarregado(s) para outro fim, designadamente comercial, carece de autorização do respetivo autor ou editor da obra.

Na medida em que todas as obras da UC Digitalis se encontram protegidas pelo Código do Direito de Autor e Direitos Conexos e demais legislação aplicável, toda a cópia, parcial ou total, deste documento, nos casos em que é legalmente admitida, deverá conter ou fazer-se acompanhar por este aviso.

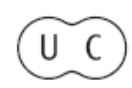




\section{REVISTA DE HISTÓRIA DAS IDEIAS 5}

\section{António Sérgio}

*

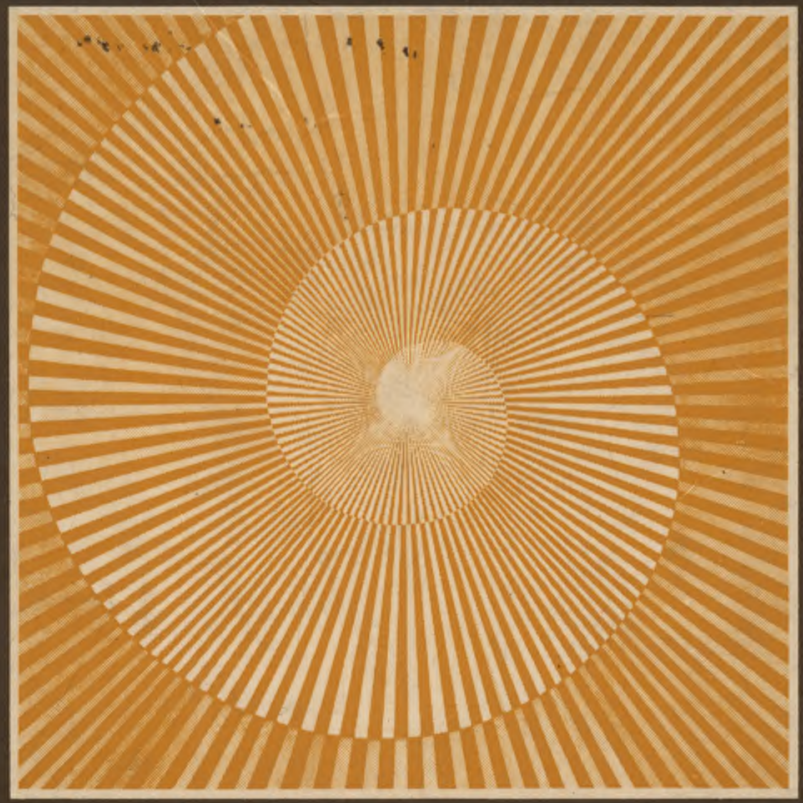

INSTITUTO DE HISTÓRIA E TEORIA DAS IDEIAS FACULDADE DE LETRAS 
VASCO DE MAGALHÃES-VILHENA *

\title{
EM TORNO DO IDEALISMO HISTÓRICO-SOCIAL DE ANTÓNIO SÉRGIO * **
}

\author{
À memória de António Sérgio, \\ Amigo querido, a quem tanto devo \\ o que sou.
}

«....não há nada, nos meus escritos, do materialismo histórico de Carlos Marx».

António Sérgio, Tréplica a Carlos Malheiro Dias sobre a Questão de O Desejado, ed. «Seara Nova», Lisboa, 1925, p. 57.

«....é pois inexacto o filiar no materialismo histórico (como se tem feito) a doutrina da Historia de Portugal de António Sérgio (edição Labor, Barcelona e Madrid), apesar de ser toda ela organizada, de facto, em função de problemas económicos. O que não quer dizer que não seja justificada a apropriação que fizeram dessa História os socialistas portugueses».

António Sérgio é, como podemos testemunhar, o autor desta nota não assinada na Seara Nova, XIV, n. ${ }^{\circ} 427$, Lisboa, 1935, p. 300.

* Faculdade de Letras da Universidade Clássica de Lisboa.

** O nosso livrinho António Sérgio. O Idealismo Crítico $e$ a Crise da Ideologia Burguesa foi publicado em 1964 nas edições da «Seara Nova». Logo após, começámos um trabalho de revisão e ampliação deste texto, que, no essencial, ficou praticamente concluído no ano seguinte. Constituído em mais de dois terços por material inédito, o novo original carecia todavia de um certo número de novas notas e acrescentos. Esse facto, de concerto com o surgir de novos polos de interesse, com a elaboração de outros trabalhos cuja importância nos pareceu então prioritária, não falando já nos imprevistos que a vida vai reservando, foi quanto bastou para que durante quase vinte anos este manuscrito ficasse em repouso. Até que... as exigências do centenário de Sérgio e a vigilante insistência de um grandíssimo amigo, António Melo, que se interessa pelos nossos papéis, nos fizes- 
«Em resumo: reconheço a realidade de numerosos factos que têm sido apontados no acontecer histórico pelos que se chamam a si mesmos «materialistas históricos»: mas vejo nas origens desses mesmos factos umas tantas ideias que criou a mente, e no quadro interpretativo que deles concebo não podem surpreender-se quaisquer feições a que convenha o epíteto de "materialistas». Por preguiça mental, a toda interpretação de natureza económica se apõe logo o rótulo de «materialista»: porém, nas várias actuações por motivo económico dá-se sempre a intervenção de factores mentais, e o escritor que propõe a interpretação económica só merece o nome de materialista histórico se aceitar de facto uma concepção materialista acerca da natureza desses factores mentais, por os ter na conta de epifenómenos, de «reflexos das coisas nos cérebros dos homens»: ora, parece-me evidentíssimo não ser esse o meu caso. Em mim, as interpretações económicas dos aconteceres históricos não têm coisa alguma de materialistas; para mim, os sucessos resultam das ideias dos homens (embora ideias sobre vantagens económicas) e as ideias para mim não são reflexos das coisas: são livres criacões do intelecto humano, intelecto que concebo como radicalmente dinâmico, tomando a iniciativa das perguntas, a iniciativa das respostas: para mim, a própria percepção é uma criação do espírito; e a filosofia implícita nos meus escritos foi sempre uma filosofia da actividade pura, da espontaneidade da mente, da sua sintética criatividade na percepção e no saber».

António Sérgio, Prefácio da Segunda Edição: Ensaios, I, Atlântida, Coimbra, 1949, pp. 60-61.

«....os factores dos acontecimentos históricos são as ideias dos homens que intervêem neles.

Sim, as ideias: pois não cuido que as ideias sejam «reflexos das coisas»: presumo que as ideias são criações da psique, e que por meio das ideias que por nós concebemos é que os objectos do pensamento são criados. Por

sem decidir, apesar dos inconvenientes que cremos antever, a publicar-lhe um capítulo. Tal como o volume de 1964 era um desenvolvimento de um pequeno folheto mais antigo, a que o próprio Sérgio se referiu com benevolência, também a nova versão, substancialmente aumentada, representa um terceiro estádio de desenvolvimento da nossa exposição da sua doutrina a que procurámos, conforme ao seu desejo, acrescentar a crítica. O texto do capítulo que aqui se publica, encurtado de alguns lances, é pois o da versão de 1965. Apenas algumas referências bibliográficas foram substituídas por outras mais recentes para maior comodidade e mais adequada informação do leitor, o que não nos é possível em rigor omitir. Era essa a intenção. Mas não se volta a um texto antigo sem lhe introduzir alterações sensíveis, ainda quando o mesmo espírito permanece. Os tempos mudaram. Aspectos novos assumem a uma nova luz um outro relevo. Modificou-se a história que se faz e com ela modificou-se também a história que se escreve. De aí o estado presente de um escrito antigo. 


\section{Idealismo Histórico-Social}

outras palavras: que só há objectos para a inteligência depois de a própria inteligência os haver criado.

Sempre que um homem quer realizar uma ideia, porém, topa em condições materiais circunstantes, que o desviam da linha em que pensou seguir, ou que determinam a linha em que ele terá de seguir. Condições circunstantes da estrutura geográfica; condições circunstantes de ambiente clímico; condições circunstantes de posição no globo; condições circunstantes de natureza económica; condições circunstantes de vizinhança humana.... Circunstâncias condicionantes, não factores de história: factores, propriamente, são-no sim as ideias.

.... Eu sou em tudo fundamentalmente idealista».

António Sérgio, «Explicação e subsunção sob fórmulas gerais», Aqui e Além, Revista de Divulgação Cultural, n. ${ }^{3}$, Lisboa, 1945, pp. 20-21.

É um facto, como vimos noutro ensejo 0), que foi a propósito de questões de ciências matemáticas e naturais contemporâneas que António Sérgio - pelos anos 30 - construiu e estabeleceu em toda a sua plenitude o corpo de ideias mais elaboradas e mais características suas do que, em tempos, e com o seu assentimento, designámos por o seu idealismo crítico. São essas ideias que um dia ele próprio denominou, com a sua fina ironia habitual, as suas «heresias epistemológicas». Mas não é menos verdade que, em grande parte, eram algo diversas as suas preocupações iniciais como diz, ao referir-se, em 1925, à «atmosfera de espírito em que [se achava] envolto ao tempo em que saía da adolescência» e depois ao defrontar «esse mar tenebroso por onde vagueou aos vinte anos» ( ${ }^{2}$ ), ao afundar da monarquia, e que ele tão eloquentemente soube evocar nos Prefácios às duas primeiras edições do tomo I dos seus Ensaios.

De facto, as suas preocupações iniciais aquando da proclamação da República e dos anos turvos da sua implementação, embora evidenciassem já o marcado interesse filosófico de que as Notas sobre os «Sonetos»e as "Tendências Gerais da Filosofia» de Antero de Quental são testemunho, levarammo, ainda de certo modo, na esteira de Antero, mas já dis-

O «Em Torno da Génese do Idealismo Filosófico de António Sérgio», in Homenagem a António Sérgio, Academia das Ciências de Lisboa, 1976, pp. 123-145. Inserto agora no nosso livro Antigos e Modernos. Estudos de História Social das Ideias, Livros Horizonte, Lisboa, 1983. 1949, p. 48.

C) A. Sérgio, Prefácio aos Ensaios, I*, Atlântida, Coimbra, 
tanciando-se de ele, a inquirir e a meditar sobre «os vícios históricos», de raiz fundamentalmente económica, da sociedade portuguesa ( ${ }^{3}$, causa primeira e decisiva da «decadência e do isolamento dos povos peninsulares» desde quase os primórdios da nacionalidade $\left({ }^{4}\right)$, e a reflectir sobre o necessário e instante ressurgimento nacional. Desde o princípio, pois, a preocupação socio-histórica pelos destinos da grei portuguesa está na raiz do pensamento de António Sérgio.

Mas se idealismo crítico é a designação que mais convém ao idealismo de Sérgio, mais consentânea com a sua feição kantiana e pós-kantiana, - e mormente ao seu idealismo gnoseológico, - quanto ao seu idealismo na história, à sua preocupação pelo social, idealismo histórico-social é, por certo, quanto a nós, a que melhor quadra às suas concepções historiográfico-sociológicas. Aliás, «ensaio histórico-social» (5) propôs António Sérgio para demarcar a natureza do problema que era seu propósito tratar no que devia ser, se as circunstâncias políticas ambientais lhe não tivessem coarctado os meios, a sua obra de maior fôlego, a índole particular do seu estudo e o ponto de vista sob o qual o perspectivava, ao explicar-se sobre a atitude mental que presidia à feitura de essa sua obra. Mas idealismo histórico-social é designação que se adequa à própria feição das suas reflexões filosófico-sociológicas, políticas, económicas mesmo, éticas e pedagógicas do seu ensaísmo de sempre.

De aí que consideremos a expressão idealismo histórico-social a que melhor cabe à visão filosófico-sociológica da problemática histórica de Sérgio.

Inquirido certa ocasião, em 1940, sobre alguns escritores que influiram na sua formação intelectual, respondeu um dia Sérgio e a resposta, porque significativa, é de reter: «Pelo que

(3) Consideraç̃̃es Histórico-Pedagógicas, Porto, 1915, p. 49. Cf. Bosquejo da História de Portugal, Lisboa, 1923, p. 58.

(4) Em O Problema da Cultura e o Isolamento dos Povos Peninsulares, Porto, 1914, são frequentes as alusões a Antero e até referências precisas e uma longa citação da conferência do Casino, de 1871: por ex., pp. 14, 26, 37-40.

( ${ }^{\circ}$ Historia de Portugal, I: Introdução Geográfica, Portugália. Lisboa, 1941, p. 7. Esta obra foi logo apreendida pela PIDE e por isso retirada da circulação (cf. Ensaios, VIII, Lisboa, 1958, pp. 7 e ss.). «Sociológica História de Portugal» lhe chamou posteriormente, in "Prefácio» ao $1.0^{\circ}$ caderno da sua Antologia Sociológica, Ed. do Autor, Lisboa, 1956, p. 11 (agora in Obras Completas, Sá da Costa Editora, Lisboa, 1978, p. 7.). Reeditada postumamente com o novo título definitivo que num seu exemplar o autor entretanto the fixou: Introdução Geográfico-Sociológica à História de Portugal, nas Obras Completas, Sá da Costa Editora, Lisboa, 1973. 
respeita aos escritores portugueses, talvez tivesse havido influência de dois: o Antero dos opúsculos sociais e o Oliveira Martins, economista - o que escreveu a Inglaterra de Hoje, a Circulação Fiduciária, o Projecto de Fomento Rural, etc. Talvez eles, em parte, me houvessem levado a ver os problemas pelo prisma económico-social, e não predominantemente pelo das instituições meramente políticas» $\left.{ }^{6}\right)$. Foi de facto predominantemente através de análises concretas das realidades sociais portuguesas (tanto do passado como do presente e tendo sempre no horizonte o futuro) que se afirmou a concepção historiográfica de Sérgio. Concepção propriamente sociológica, de história social total, e não tão-só «histórica», à maneira artificiosa tradicional $\left({ }^{7}\right)$.

(6) «Uma entrevista com António Sérgio», por Gentil Marques, O Diabo, VI, n. ${ }^{\circ}$ 279, Lisboa, 1940, p. 7.

O São característicos e esclarecedores a este propósito artigos de marcado carácter polémico, - hoje pouquissimo conhecidos e relembrados. Citemos nomeadamente: «Ideal e facto sensível, política e ciência, meios e fins», Seara Nova, VII, n. ${ }^{\circ}$ 144, Lisboa, 1929, pp. 443-446; "Método científico, História, Política e Tradição», Seara Nova, VII, n. ${ }^{\circ} 151,1929$, pp. 99-104, n. ${ }^{\circ} 153,1929$, pp. 134-138 e n. ${ }^{\circ} 154,1929$, pp. 153-157: «Idealismo e realismo. «Morale d'abord»e «Politique d'abord», Seara Nova, VII, n. ${ }^{\circ} 163,1929$, pp. 293-301; «Ora até que enfim!», Seara Nova, VII, n. $.^{\circ} 170,1929$, pp. 19-25. - Nestes artigos exprime Sérgio, com extrema clareza, entre outras coisas, alguns pontos capitais do seu idealismo histórico-social. Por exemplo: «que são as coisas, que são as palavras de um documento histórico, senão sinais, unicamente interpretáveis pelas revelações interiores da consciência? .... Dispensar as revelações da consciência é anular tudo; e, longe de fundar na experiência histórica as revelações interiores da consciểncia, são as revelações de consciência que servem de base a toda a história, de toda a experiência, a toda ciência, a todo saber.... Esse fundamento de todas as coisas, essa única realidade incontestável.... é o facto de consciência.... Rejeito em tudo o realismo.... Não me fundo em suma em nenhuma coisa: fundo-me na consciência e nas relações. A sociedade, para mim, define-se em termos de consciência por meio de relações intelectuais. Pertencer a uma sociedade, para o idealista, redunda em conceber um certo todo, - ou, melhor, uma relação, - de que nós constituímos um termo, e os outros sócios o outro termo. A sociedade é a relação....» («Idealismo e Realismo. «Morale d'abord» e «Politique d'abord», Seara Nova, VII, n. ${ }^{\circ} 163$, Lisboa, 1929, pp. 296-297. Cf. o que acerca de esta concepção idealista típica do ser social como uma idealidade, Sérgio já escrevera em «Educação e Filosofia», no tomo I dos Ensaios: "A sociedade.... é sempre relativa a um sujeito pensante, está sempre como ideia num sujeito; mas o indivíduo existe sempre numa relaçẫo com sociedades, a mais imediata das quais é a sociedade dos seus progenitores. A consciência do eu implica a consciência do não-eu; e implica não só a consciência do não-eu, mas a consciência do outro-eu, do "sócio", do "semelhante», do companheiro; e essa ideia do outro-eu não é um reflexo superficial, mas uma das tendências mais profundas, uma das determinações essenciais da actividade do nosso espírito" - Ensaios, I, Rio de Janeiro, 1920, pp. 137-138). 
Se Herculano, como é sabido, iniciou em Portugal com rasgos pessoais incontestáveis a historia crítica, «que pelo próprio facto de ser crítica - como diz Sérgio $\left({ }^{8}\right)$-apresenta uma fisionomia de excepção no patrimonio literário português»: a historiografia tal como de certo modo a concebiam os historistas da «Escola histórica alemã» e eventualmente os historistas franceses da época da Restauração, Antonio Sérgio- e nenhum outro - foi o introdutor, na cultura portuguesa, da historia sociológica. Nesta base, os seus escritos de historia social e «económico-social» $\left({ }^{9}\right)$ abriram entre nós mais do que quaisquer outros $\mathrm{o}$ caminho à renovação da pesquisa de natureza histórica. E em primeiro de tudo - facto entre todos capital - à renovação da historiografia nacional pela muito particular insistência de Sérgio sobre o processo de desenvolvimento das estruturas socio-económicas da burguesia portuguesa, com as suas lutas de classe próprias, no quadro social mais lato do processar da civilização europeia. Do seu impulso, e tão só dele, neste sentido, arrancou, geralmente falando, o mais valioso da historiografia portuguesa contemporânea.

Mas não foi fácil. E isso, sim, era previsível.

Aí está. Com efeito o tempo não era de todo propício. Prevaleciam na altura o positivismo na história $\left({ }^{10}\right)$, o socio-

(®) Herculano, Sobre História e Historiografia (Da «História de Portugal» $e$ dos "Opúsculos»). Selecção, prefácio e notas de A. Sérgio, ed. «Seara Nova», Lisboa, 1937, p. 13.

${ }^{\circ}$ ) António Sérgio, O Problema da Cultura e o Isolamento dos Povos Peninsulares, Porto, 1914, p. 12. A «advertência» inicial de este escrito sergiano que tão fecundas ideias contém já em si, anunciadoras de futuros e ricos desenvolvimentos, note-se, é datada do Rio de Janeiro, Dezembro de 1913, e nela se encontra a expressão referida no texto. O corpo da conferência pronunciada no Rio em 1913, acabado de imprimir para a «Renascença Portuguesa», do Porto, em Abril de 1914, é datado também do Rio de Janeiro, onde Sérgio então se encontrava, Julho de 1913.

(10) Obras que, entre nós, muito influiram, nos fins do século XIX e nos primeiros decénios de este nosso século, no modo de pensar a história e designadamente na difusão das teses do positivismo na história: P. Lacombe, De l'Histoire considérée comme science, Paris, 1894; A. D. Xenopoi, La Théorie de l'histoire, Paris, 1908 (2.a ed. de Principes fondamentaux de l'histoire, Paris, 1894), e sobretudo - obra característica de então e por muito tempo considerada fundamental Introduction aux études historiques, por $\mathrm{Ch}$. V. Langlois e Ch. Seignobos, Paris, 1898. Ver ainda: Ernst Bernheim, Einleitung in die Geschichtswissenschaft, Leipzig, 1920 (trad. Introdución al estudio de la historia, ed. Labor, Barcelona, 1937) e Lehrbuch der historischen Methode und der Geschichtsphilosophies, Leipzig, 1908; Wilhelm Bauer, Einlei- 
logismo (de Durkheim, de Lévy-Bruhl, entre outros), o eruditismo e o historicismo arquivísticos, e o estéril filologismo formal, e contra eles teve Sérgio que lutar, sem tréguas $\mathrm{C}^{11}$ ). Não o puderam entender. Houve, é certo, quem aproveitasse, com vasto saber e alguma visão, mas com certas limitações também, sugestões sobre a importância primordial do econó-

tung in die Geschichtswissenschaft, 1921, 1927² (trad.: Introdución al estudio de la historia ${ }^{2}$, Barcelona, 1952).

Sobre a penetração, a propagação e a influência permanente das ideias sociológico-políticas do positivismo, particularmente da facção chefiada por Littré, e a sua inserção na tradição cultural portuguesa desde os três últimos decénios de oitocentos, situada no seu quadro socio-ideológico, dando o necessário relevo às condições epistemológicas necessárias ao aparecimento, nos países anglo-saxónicos, em França e entre nós, do projecto sociológico positivista, sem subestimar as reais distanciações, veja-se o a tantos títulos excelente estudo, pertinente e bem documentado de Fernando de Almeida Catroga, Os Inícios do Positivismo em Portugal. O seu Significado Político-Social, Instituto de História e Teoria das Ideias, Coimbra, 1977. Na verdade, como Fernando Catroga demonstra (pp. 28-33), a introdução entre nós do pensamento positivista comteano no campo dos fenómenos sociais - e mais concretamente ao nível do Direito, antevendo a sua dimensão socio-política orientada para um republicanismo de inspiração littréana, e, por um tempo, proudhoniana, - ter-se-ia iniciado já em 1865-1866 em Coimbra, com Manuel Emidio Garcia, anteriormente portanto à adesão, em 1872, de Teófilo Braga ao sistema comteano. O idealismo na história, de Sérgio, situa-se nos antípodas do positivismo na história. Mais: Sérgio era em tudo anti-positivista - sem excluir o positivismo inglês - e o seu anti-positivismo declarado não é provavelmente estranho, parece-nos, à aliança entre nós do movimento positivista, na sua variante portuguesa, com a ideologia dominante do demo-republicanismo, impugnados ambos por António Sérgio.

(21) Não cabe aqui referirmo-nos em pormenor a essas lutas que, embora revelem de maneira exacta a atmosfera de espírito em que Sérgio por esse então se achava envolto, ao combater o que chama «essa romântica maneira de conceber a história, de interpretar a obra das navegações portuguesas», ou ainda: o "«carácter arquivistico» do nosso «senso histórico», a nossa «inclinação para o historicismo e o filologismo formalísticosı) com o total desprezo pela problemática intelectual. Cumpre-nos porém registar aqui um documento sergiano importante; importante em si como expressão do pensamento historiográfico-filosófico de Sérgio, mas de grande relevância igualmente para situar valorativamente a posição de António Sérgio no ambiente intelectual do seu tempo, e a que, nesta perspectiva, pouco ou nada se tem atentado: «Historicismo arquivistico, Miragem retórica e Problemática intelectual», Seara Nova, XI, n. ${ }^{\circ}$ 310, Lisboa, 1932, pp. 339-345. O facto de este escrito ter sido ulteriormente retomado com acrescentos num dos volumes dos Ensaios, não dispensa a leitura do texto polémico original enquadrado na época. 
mico na história nacional (12). Outros apropriaram-se indevidamente de outras ideias suas, não as inteligindo, todavia, até o fim, e outros houve que acoimaram de «ruidosa e vã cavalaria intelectual» umas tantas das suas mais estimulantes e férteis hipóteses que propusera. Os mais numerosos, porém, tudo entenderam ao revés. Aos poucos, todavia, se os problemas que posicionou e as hipóteses a explorar por ele aventadas nos seus primeiros escritos históricos, como ele de resto o reconheceu, «esbarraram a princípio com oposições enérgicas, não deixa de ser certo que com o andar do tempo foram elas singrando entre parceis e escolhos, e que já hoje existem sabedores de mérito que se não pejam de admiti-las como soluções possíveis.... Que vão mesmo além: que carreiam documentos em seu favor. Isto justifica-me, ao que me quer parecer, de não abandonar a orientação tomada....» $\left({ }^{1 S}\right)$

De qualquer modo, o que mais releva sempre para Sérgio, mais, muito mais do que a rejeição ou mesmo a aceitação das hipótese que adiantara há muito nos seus escritos sobre este ou aquele ponto avulso da nossa história (embora evidentemente the aprouvesse ver como não poucos dos seus pontos de vista faziam caminho por entre as muitas dificuldades, os reparos e as oposições $\left({ }^{14}\right)$, era a atitude mental,

(12) Ver: João Lúcio de Azevedo, Épocas de Portugal Económico. Esboços de História, Lisboa, 1929. Na nota "Ao Leitor», a abrir, diz o autor que «os estudos que compõem o volume obedecem ao conceito materialista, não único, mas certamente indispensável para a compreensão da história» (p. 7). Como ele próprio contou um dia a Sérgio, consoante este recorda (cf. «Evolução Económico-Social da Nação Portuguesa", O Diabo, VII, n. 301 , Lisboa, 1940, p. 3), tinham-lhe causado forte impressão as palavras de abertura das "Nótulas Preambulares» à Antologia dos Economistas Portugueses. Selecção, prefácio e notas de António Sérgio, Lisboa, 1924. O passo de Sérgio a que aqui se alude é por nós citado páginas adiante.

(") História de Portugal, t. I, Introdução Geográfica, Liv. Portugália, Lisboa, 1941, p. 9.

(M) Ver, a este propósito, na História de Portugal, I: Introdução Geográfica, Lisboa, 1941, p. 9, e a pp. 237-238 a nota relativa à adesão de Jaime Cortesão à conjectura de Sérgio acerca do valor do comércio marítimo no próprio início da nacionalidade. Ora bem. A inegável prioridade das conjecturas de Sérgio sobre as origens comerciais marítimas e a relevância das fainas dos portos da orla atlântica de Portugal é, por curiosa coincidência, lembrada pelo próprio Sérgio, com referências precisas a trabalhos seus muito anteriores, designadamente num relevantíssimo artigo «Em Torno de um Livrinho», Seara Nova, IX, n. ${ }^{\circ}$ 201, Lisboa, 1930, pp. 140-142 (reimpresso depois nos Ensaios, III, Porto, 1933, pp. 285-289), precisamente no mesmo número da revista em que Jaime Cortesão, também então no exílio, em Paris, como Sérgio, publica um artigo intitulado «O Problema das Relações entre a Geografia e a Autonomia Política de Portugal» (Seara Nova, IX, n. 201, 
atitude «prescrutadora e crítica - problemática» (1B) - que assumia, a sua maneira de considerar os factos da nossa história. O que, em suma, the importava antes de mais era a natureza da sua indagação da problemática histórica. E essa atitude por parte de Sérgio é indubitável e vê-se ter sido o seu pensar de sempre, ainda que só explicitado, por vezes, ao acaso das circunstâncias e, por isso mesmo, passado na imensa maioria dos casos despercebido ao olhar distraído e indiferente dos especialistas lusos. Ora, a indagação preocupante para Sérgio não era, nunca foi, apenas histórica, simplesmente histórica, mas - não é demais repeti-lo - histórico-sociológica, e assente sempre, de raiz, numa constante e atenta reflexão filosófica ${ }^{(16)}$.

Lisboa, 1930, pp. 133-137), artigo onde retoma, pensamos, o tema de uma conferência que pronunciara na Universidade Livre de Lisboa, em Janeiro de 1925, artigo onde, estranhamente, se não topa o nome de Sérgio. Esse artigo de Cortesão é, em muitos pontos, um primeiro esboço ou prólogo, pouco conhecido, de um trabalho, esse de todos conhecido: "Os Factores Democráticos na Formação de Portugal», História do Regímen Republicano em Portugal, sob a direcção de Luís de Montalvor, vol. I, Lisboa, 1930, pp. 13-97. Ver também o que Sérgio escreve, em 1925, no ensaio «Repercussões de uma Hipótese: Ceuta, as Navegações e a Génese de Portugal», Ensaios, IV, Lisboa, 1934, pp. 229-275 , referindo-se outrossim às hipóteses lançadas nas Considerações Histórico-Pedagógicas, publicadas havia dez anos, «mas que desde muito andavam bailando no [seu] cérebro» (p. 235): "Como se sabe, Jaime Cortesão, em trabalhos admiráveis de erudição luminosa, admite actualmente a nossa hipótese sobre a influência da burguesia comercial-marítima na formação de Portugal e nos Descobrimentos». E ainda: «Jaime Cortesão concorda connosco [na ocorrência, no seu trabalho «A Tomada e Ocupação de Ceuta», Boletim da Agência Geral das Colónias, n. ${ }^{\circ}$ 5, Lisboa, 1925, mas também em outro artigo a que Sérgio se refere: «Do Sigilo Nacional sobre os Descobrimentos», Lusitânia, n. ${ }^{\circ}$ 1, Lisboa, 1924] em ver na tomada e ocupação de Ceuta o primeiro episódio de um plano político cujo fim remoto seria a índia e a decisiva solução dos problemas básicos do alto comércio e da finança europeia. A nossa hipótese, porém, surge minuciada e continuada pela pesquisa do historiador, que agora marca, em nosso entender, um momento excepcional, decisório, da fase crítica e positiva da investigação histórica portuguesa relativa às Navegações».

(“) Ensaios, IV, Lisboa, 1934, p. 214. Cf. IV², Lisboa, 1959, p. 216.

(") Ele próprio o disse não raras vezes, mas pouco se atentou nisso. Curiosamente, de resto, é por esse então, de início, em livros e até em artigos de índole preferentemente histórica (e a que noutro lance nos referimos) que avultam páginas suas de prosa doutrinal filosófica da maior relevância. É o caso, por exemplo, das «Divagações Proemiais» do tomo I da História de Portugal, Lisboa, 1941, pp. 22 e ss. e de Em Torno da Designação de "Monarquia Agrária», Lisboa, 1941, v.g. pp. 5 e ss. e 119 e ss. 
Se, em Sérgio (como ele assevera de Herculano), «se vislumbra o racionalista a combater o histórico» (17) - o passado morto e soterrado, com suas lendas e falsificações, - é porque Sérgio, muito mais sem dúvida do que Herculano, tem da História uma concepção viva e actuante. Numa palavra: social e de crítica social.

Ora, na problemática crítica de Sérgio onde avulta para nós marcadamente a sua sagaz preocupação pelo social, pela crítica social, pela natureza, peculiaridades e significado social das obras e das suas incidências e repercussões, que suscitaram e as interpretações que de facto influíram, - Sérgio não buscou por via de regra no essencial enunciar críticas de literatura ou de arte usando de critérios propriamente de teor literário ou estético (embora por vezes o tivesse sabido fazer e como ninguém entre nós) — aliás a preocupação exclusiva dos literatos, meramente literatos ou estetas. A Sérgio o que mais lhe importa, neste aspecto da sua multímoda actividade de escritor de ideias, é realizar crítica social histórica ou de cariz sociológico, ou social-pedagógica, ou pedagógico-política $\left({ }^{18}\right)$.

E assim, António Sérgio que sempre insistiu na ideia de não ser, nem querer ser, propriamente historiador, mas tão-só «simples ensaísta sobre a nossa história» (19), posicionando problemas, alertando para dificuldades que se lhe deparavam e em que não se reparara, aventando novas e excitantes hipóteses de trabalho, sobre pontos antes inadvertidos, abriu rotas novas, insuspeitadas, e que talvez nem ele próprio ousasse prever, à historiografia portuguesa nos mais variados domínios $\left({ }^{20}\right)$.

(") Herculano, Sobre História e Historiografia, ed. «Seara Nova», Lisboa, 1937, p 14. Cf. pp. 110 a 120.

(15) Tudo isto - que é de primordial importância para compreender a pleno o ensaísmo sergiano está sobejamente patente, por forma exemplar, nos luminosos ensaios sobre Eça, sobre Camões (o da lírica mas não só esse), sobre Antero, Oliveira Martins, Herculano, Fernão Lopes, António Vieira, Tolentino ou Junqueiro, mas vejam-se ainda, nomeadamente, as suas reflexões acerca da feição própria da sua crítica nos prefácios das duas primeiras edições do primeiro tomo dos Ensaios, P, Rio de Janeiro, 1920, pp. 11 e ss.; P, Coimbra, 1949, pp. 11 e ss.; bem assim como no artigo «Crítica Literária e Crítica Social», O Diabo, VI, n. ${ }^{\circ} 293$, Lisboa, 1940, pp. 1 e 6. 1941, p. 66.

(") Em Torno da Designação de "Monarquia Agrária», Lisboa,

$(* \circ)$ Um excelente trabalho, paciente e meticuloso, de grande utilidade - indispensável mesmo - para o conhecimento e estudo da vastíssima e variada obra de Sérgio, extremamente dispersa por livros, opúsculos, revistas e jornais, na grande maioria dos casos de dificílimo 


\section{Idealismo Histórico-Social}

Num artigo habitualmente descurado pelos leitores de Sérgio, mas cujo significado e importância para a intelecção das suas ideias não passou obviamente despercebido ao próprio Sérgio que, em 1913 (21), a ele alude sem referências precisas, e cita longamente em O Problema da Cultura e o Isolamento dos Povos Peninsulares (22), podiam ler-se, na verdade, considerações edificantes sobre a ociosidade peninsular, o parasitismo nacional do Estado, o eclesiástico, o cortesão e o militar. Nesse artigo, como nos opúsculos de 1914 e de 1915, visiona-se bem a divergência profunda que distingue António Sérgio, interventor político e pedagogista, apóstolo cívico (como a si se chamava) e reformador social preocupado ao mais alto ponto pelas estruturas socioeconómicas, da posição de um Jaime Cortesão, vocacionado principalmente para uma tarefa de historiador mais à maneira convencional sem a agudeza do sentido socioeconómico, tão pronunciada em Sérgio a despeito do seu idealismo.

Anos depois, num curto artigo que também não despertou as atenções dos especialistas, dado talvez o carácter circunstancial e efémero da revista que o publicou e dada possivelmente a «estranheza» do título (23), Sérgio procurou precisar a sua peculiar posição, embora infelizmente ao que nos parece, sem resultado apreciável, sobre um ponto primacial da sua maneira de entender e tentar explicar a história portuguesa. Ponto primacial e ideia directriz que preside e orienta tudo o que escreveu sobre a história da nação.

Escreve ele: «Bem sei que a operação de explicar uma coisa, para a quase totalidade dos homens cultos, consiste essencialmente em submeter essa coisa ao império absoluto de uma fórmula geral, que dominaria todas as outras da mesma espécie; para mim, porém, explicar um sucesso não é nada disso: é intuir um tecido de relações entendíveis que o ligam a um todo em que ele se acha incluso.

acesso e de que raros têm notícia, - é a contribuição para a Bibliografia de António Sérgio, organizada por A. Campos Matos, ed. "Vértice», Coimbra, 1971. Tanto basta para nos dispensarmos de entrar aqui em pormenores.

(21) «O Parasitismo peninsular. Carta a Jaime Cortesão», A Vida Portuguesa, n. ${ }^{\circ}$ 20, Porto, 1 de Dezembro de 1913, pp. 153-159. Cf. a carta de Cortesão a que esta de Sérgio responde: «O Parasitismo e o anti-historismo. Carta a António Sérgio», ob. cit., n. ${ }^{\circ}$ 18, de 2 de Outubro de 1913, pp. 137-139. Mormente no n. ${ }^{\circ} 23$ de $A$ Vida Portuguesa, de 1 de Março de 1914, pp 21-22, Sérgio publica ainda: «O Problema da cultura».

(22) O Problema da Cultura e o Isolamento dos Povos Peninsulares, Porto, 1915, pp. 47 e ss.

(a) «Explicação e Subsunção sob Fórmulas Gerais», Aqui e Além, Revista de divulgação cultural, n. ${ }^{\circ}$, Lisboa, 1945, pp. 18-22. 


\section{Antônio Sérgio}

Por outro lado, quando se recorre ao princípio da causalidade para dar conta do surgimento de um certo facto, imagina-se um algo isolado e absoluto, que seria a causa do sucesso em questão, dando-se que este último é fantasiado, outrossim, como sendo uma coisa absoluta e isolada, na sua qualidade de respectivo efeito. Ora, também nisto me afasto da concepção comum. Ao que suponho, não há facto que se distinga de maneira absoluta na realidade total em que ele é só parte, e que nos não force a pô-lo em relações entendíveis com a multiplicidade de circunstâncias em que se encontra envolto. Pensando assim, é claro que me não poderia aflorar ao espírito o agarrar-me às fórmulas que me atribuem. Em meu entender, cada facto particular do desenvolvimento histórico requere um exame particular também, para a relacionação particular que o caracteriza a ele» (24). " .... Ora, não seria uma estreitíssima preocupação dogmática a de pretender explicar toda a variedade da história por uma fórmula geral de natureza geográfica, ou por uma fórmula geral sobre «factores económicos»?» (25) « .... Ideias estas que se ligam a preceito com o que [algures (26)] ficou exarado: «Ou muito me engano, ou conhecer uma coisa é relacioná-la com outras, com o todo estruturado em que tem seu lugar, que logicamente precede a parte onde tudo existe em relacionações recíprocas. Ao que julgo provável, o genuíno universal é a ligação com o todo: não é a ideia geral, não é a noção abstracta....» $(27)$.

«Portanto, em primeiro lugar, rejeito a esperança de que uma ideia geral, de que uma noção abstracta (fórmula de determinismo de natureza geográfica; fórmula de determinismo de natureza económica; fórmula de determinismo de outra natureza qualquer) seja coisa capaz de compendiar sob si toda a série de acontecimentos da evolução humana; em segundo, creio que cada facto particular da história exige um exame particular também, para se chegar por aí a uma explicação definida, que é um feixe de relações que caracteriza o facto ....»(28). «Explicar, se nos não enganamos, não é subsumir sob uma fórmula geral, mas urdir o tecido de relações ${ }^{(*)}$

(M) Ob. cit., p. 18.

(*) Ob. cit., p. 19.

(") Na História de Portugal, apreendida a quando da publicação que Sérgio, habilmente, omite de referir.

(") História de Portugal, I: Introdução Geográfica, Portugália, Lisboa, 1941, p. 20.

Além, ob. cit., pp. 19-20.

«Explicação e Subsunção sob Fórmulas Gerais», Aqui e 


\section{Idealismo Histórico-Social}

entendíveis que ligam cada aspecto da realidade estudada ao todo relacional a que se encontra unida» $\left({ }^{29}\right)$.

Num artigo-síntese sobre a evolução económico-social da nação portuguesa, publicado pouco antes de vir a lume o primeiro - e único — tomo da sua História de Portugal, a que os imperativos da política fascista então reinante abruptamente puseram termo, António Sérgio esquissou assim uma pequena parcela, mas exemplar, do pensamento da obra:

«A intensa dedicação às actividades do mar (resultante de um desfavorável condicionamento agrícola) [actividades intensas já originariamente, desde princípio, no próprio despontar da nacionalidade, e em todo o primeiro ciclo da existência do país (1140-1450), mas que mais ainda avultaram e se intensificaram com a expansão oceânica estribada no capitalismo mercantil da burguesia cosmopolita na sequência natural da revolução burguesa de 1383-85 (30)] habilitou-nos a ser um primacial instrumento da obra da expansão da burguesia europeia. Ao que me tem querido parecer, foi dentro dessa obra que Portugal nasceu, dentro dela que realizou a sua missão histórica. Como já disse algures, as grandes navegações dos nossos avós e a criação do reino de que foram membros parecem-me duas fases de um fenómeno único: o de passagem da economia predominantemente agrícola, local, fechada, a que o domínio dos Árabes no Mediterrâneo havia compelido a gente europeia, para uma larga economia comercial-marítima. Desta forma, o desenvolvimento da indústria nas regiões flamengas, a tomada de Lisboa pelos Cruzados, a conquista de Ceuta por D. João I, a de Malaca por Albuquerque um centenar de anos depois, afiguram-se-me como fases de um movimento único, como que pontos distantes de uma só trajectória. $\mathrm{O}$ desenvolver da burguesia comercial da Europa seria a própria substância da nossa história, - entenden-

(29) Ob. cit., p. 22.

$\left.{ }^{30}\right)$ «A revolução foi burguesa», diz Sérgio em nota, não querendo «significar com isso (como imaginaram alguns leitores) que foram os altos burgueses cosmopolitas que andaram armados pelas praças, [....mas] por ser o alto burguês que serviu de meneur, por ser ele quem a inspirou, a dirigiu, a organizou por detrás da cortina, e quem tirou depois os proveitos dela». - Sobre o carácter burguês da Revolução de 1383-85, integrada no todo da transformação europeia, ver ainda o substancial «Prefácio» de Sérgio à edição da Crónica de D. João I, segundo o códice $n \circ^{\circ} 352$ do Arquivo Nacional da Torre do Tombo, de Fernão Lopes, vol. I, Liv. Civilização Editora, Porto,

1945, pp. IX-XL. Depois inserto nos Ensaios, VI, ed. Inquérito, Lisboa

1946, com o título «Sobre a Revolução de 1383-85». 
do eu por «substância», aqui como sempre, uma lei de unidade e de continuidade das coisas» $\left({ }^{31}\right)$.

Eis aí. Ao que estamos em julgar, e sempre assim nos quis parecer, os seus estudos reputados de índole «histórica» e nos quais se dão aos fenómenos económicos, aos antagonismos sociais e às lutas de classe particular realce (32), são fundamentalmente análises sociológicas, pois se situam àquele nível do conhecimento social global que busca investigar os «fenómenos sociais totais» (Marcel Mauss). Mais precisamente: de «sociologia histórica» e de «sociologia politica», e até de «sociologia do conhecimento», como é uso entenderem-se as expressões no que toca, entre outros, a Max Weber, a Max Scheler, a Troeltsch, a Sombart, a Karl Mannheim (33). É possivelmente com o último (cuja obra é ulterior à elaboração do pensamento de Sérgio) que, neste particular, a orientação sergiana parece de algum modo revelar maiores afinidades.

(31) «Evolução Económico-Social da Nação Portuguesa», in O Diabo, VII, n. ${ }^{\circ}$ 301, Lisboa, 1940, p. 3. Cf. «Em Torno de um Livrinho», Seara Nova, IX, n. ${ }^{\circ}$ 201, Lisboa, 1930, pp. 140-142, inserto depois nos Ensaios, III, Porto, 1932, pp. 285-289 com o título «A Formação de Portugal e a Política», e ainda Em Torno da Designaçáo de «Monarquia Agrária» dada à Primeira Época da Nossa História, Lisboa, 1941.

${ }^{(32)}$ Nesta óptica ver, por exemplo: O Problema da Cultura e o Isolamento dos Povos Peninsulares, Porto, 1914; Consideraçóes Histórico-Pedagógicas, Porto, 1915; Bosquejo da História de Portugal, Lisboa, 1922 (19232); Antologia dos Economistas Portugueses. Século XVII. Obras em Português, Selecção, prefácio e notas, Lisboa, 1924; Testemunhos Históricos. O Desejado. Depoimentos de Contemporâneos de D. Sebastiấo sobre este mesmo rei e sua jornada de Africa, precedidos de uma Carta-Prefácio a Carlos Malheiro Dias, Lisboa, 1924; Tréplica a Carlos Malheiro Dias sobre a Questão de O Desejado, Lisboa, I925; Camões e D. Sebastião, Lisboa, 1925; O Seiscentismo, Lisboa, 1926; Historia de Portugal, Barcelona, 1929 (o texto original português, mais completo do que o da versão castelhana, só postumamente foi editado, agora com o título do manuscrito original: Breve Interpretação da História de Portugal, nas Obras Completas, Sá da Costa Editora, Lisboa, 1972); Ensaios, I, Rio de Janeiro, 1920, pp. 279-305, 403-404 ( ${ }^{3}$, Lisboa, 1949, pp. 57-64, 306-329, 460-461); Ensaios, II, Porto, 1929, pp. 67-107, 255; Ensaios, III, Porto, 1932, pp. 285-296, 421-423; IV, Lisboa, 1934, pp. 9-13 (IV ${ }^{2}$ Lisboa, 1959, pp. 15-19, 203-241); VI, Lisboa, 1946, pp. 9-18, 153-203, 287-289; VIII, Lisboa, 1958, pp. 85-188; Em Torno da Designação de "Monarquia Agrária", Lisboa, 1941; História de Portugal, I: Introdução Geográfica, Liv. Portugália, Lisboa, 1941, pp. 45-46, 212-231.

(") Sobre o tema ver em particular: Werner Stark, The Sociology of Knowledge. An Essay and Aid of a Deeper Understanding of the History of Ideas, Routledge, London, 1958 (trad.: Sociologia del Conocimiento. El pensamiento sociológico en la historia de las ideas, Ed. Morata, Madrid, 1963) e Irving Louis Horowitz, Philosophy Science and the Sociology of Knowledge, Springfield, Illinois, 1961. De Karl Mannheim, é aqui bastante citar: Ideology and Utopia. An Intro- 
Dizemos simplesmente afinidades, analogias — para melhor o situar; seria aliás interessante também marcar as diferenças, em particular pelo que respeita a Weber e a Sombart.

O certo é que, ao revés de Weber e de Mannheim, por exemplo, Sérgio só incidentemente explanou os princípios que norteiam a sua prática sociológica. De aí, em parte, certa incompreensão de base nas interpretações que por via de regra têm sido propostas para o seu pensamento, atribuindo-lhe uma significação que, bem pesadas as coisas, se the não coaduna. A saber: que para Sérgio como para Marx (ao que uns tantos julgavam compreender, mas não compreendendo realmente nem um nem outro) o económico é não só «factor» capital, mas determinante da história em todas as suas esferas, sem exclusão do mundo das ideias. $\mathrm{O}$ facto é que, neste ponto como em tantos outros, foi a doutrina de Sérgio (como de Marx, aliás) muito mal percebida por uma parte considerável dos seus leitores. Dá-se o caso que os que se inclinaram a considerar da mesma espécie as concepções da história de Sérgio e de Marx desentenderam radicalmente uma e outra. Assim mesmo. Em parte, porém, não é porventura de excluir que de princípio certas afirmações de Sérgio o tenham por vezes levado demasiado longe neste rumo, para melhor salientar o que the era particular no modo de conceber a história portuguesa. Porém, passado o efeito de choque inicial de $O$ Problema da Cultura e o Isolamento dos Povos Peninsulares, das Considerações Histórico-Pedagógicas, do ensaio sobre a Conquista de Ceuta do Bosquejo da História de Portugal, da Antologia dos Economistas Portugueses e da Historia de Portugal (da «Labor») que são respectivamente dos anos de 1914, de 1915, de 1919, de 1922, de 1924 e de 1929, e em reacção manifesta contra as simplificações abusivas que tendiam então a generalizar-se ${ }^{(34)}$, Sérgio - como Antonio

duction to the Sociology of Knowledge, Routledge, London, 1936 (trad. Ideología y utopía. Introducción a la sociologia del conocimiento, Ed. Aguilar, Madrid, 1973), Essays on the Sociology of Knowledge, Routledge, London, 1952. - Os principais escritos originais em alemão de Mannheim (falecido no exílio em 1947), situam-se entre 1922 e 1929, mas foram sobretudo conhecidos e difundidos ulteriormente na sua versão inglesa.

${ }^{\left({ }^{3}\right)}$ Nẫo será descabido recordar aqui alguns factos: em 1925, a chamada «escola histórica» de M. N. Pokróvski e a Associação de historiadores que dirige estão no auge. (Ver O. Sokolow, «Ueber die historischen Ansichten M. N. Pokrowski», Sowjetwissenschaft. Gesellschaftswissenhaftliche Beiträge, n. ${ }^{\circ}$, Berlin, 1962, pp. 874-887). Em 1921 é publicado o livro de N. Bukhárine: Teoria do Materialismo Histórico que edições e traduções sucessivas em alemão (1922), inglês (1925), francês e espanhol (1927), e até português (trad, parcial no 


\section{Antonio Sérgio}

Banfi, como Gramsci, corno Max Weber e corno Mannheim, mas independentemente deles e muitas vezes por razões sensivelmente diferentes (em especial pelo que toca a Banfi e a Gramsci) - foi então naturalmente impelido a marcar mais incisivamente o que o distanciava da doutrinação em voga, e bem assim a repulsar intenções que desacertadamente lhe haviam atribuído. Com efeito, reiteradas vezes Sérgio se opôs resolutamente ao que, na época em que ideou os seus primeiros escritos de matéria histórico-sociológica, se entendia em geral - e mal - por "determinismo económico» e a que, anacrónicamente, uns tantos (na esteira dos Sorel, dos Loria, dos Kautsky, dos Pokróvskii, dos Bukhárine e até de algum modo (mas geralmente compreendendo-os mal) dos Lafargue, dos Labriola, dos Mehring, dos Plekhánov), obstinadamente per-

semanário $A$ Liberdade, de Lisboa) para só estas referir, tornam em pouco tempo célebre. Embora condenado severamente por alguns (sobretudo por A. M. Debórine e por Hermann Duncker, mas também por A. Gramsci e por G. Lukács) como «uma perfeita caricatura do materialismo dialéctico e em completa contradição com ele» (Kurt Sauerland, "Ueber den Kampf an der theoretischen Front», Die Internationale, 1931, n..$^{\circ}$, pp. 75-79, e n. ${ }^{\circ}$, 128-133, e Der dialektische Materialismus. Schöpferischer oder dogmatischer Marxismus, Berlin, 1932, p. 6: «Bucharin aber ist ein Vertreter des mechanistischen Materialismus gegen den sowohl Marx und Engels wie Lenin einen erbitterten Kampf führten", e pp. 235 e ss. Na sua célebre Carta ao Congresso, de 22-XII-1922, V. I. Lénine, embora apontando o grande valor teórico de Bukhárine não deixara de advertir: "As suas opiniões teóricas todavia, só com as mais expressas reservas podem ser tidas como genuinamente marxistas, pois há nele algo de escolástico (nunca estudou e, penso, nunca compreendeu cabalmente a dialéctica)» Pólnoe Sobránie Sotchinénii, 5.a ed., t. 45, Moskvá, 1964, p. 345). Ver ainda: Henri Barbusse, «Lénine et la philosophie», Commune, III, n. ${ }^{\circ} 33$, Paris, 1936, sobretudo pp. 1051-1053; Antonio Gramsci, Il materialismo storico e la filosofia di Benedetto Croce, Torino, 1948, pp. 117-168, e para uma análise histórica do acolhimento reservado na época ao tratado de Bukhárine: Aldo Zanardo, «Il «manuale» di Bukharin visto dai comunista tedeschi e da Gramsci», Studi Gramsciani, Roma, 1958, pp. 337-368). Muito pelo contrário, o manual de Bukhárine é saudado, por exemplo, pelo sociólogo burguês anti-marxista (mais tarde nazi) Werner Sombart, em 1924, como uma «ritchtige Darstellung» (Der proletarische Sozialismus, I Jena, 1924, p. 127). É também a época em que encontram ainda um eco particular as concepções sociológicas (filhas do cientismo empirista e do economismo mecanista) afirmadas pelos teóricos da social-democracia internacional que então se dão ainda por «marxistas», como Eduard Bernstein, Karl Kautsky, Max Adler, H. Cunow, Charles Andler, Rodolfo Mondolfo, Charles Rappoport, Max Beer e outros, contribuindo por seu turno para aumentar a confusão não só a larga difusão dos livros de Georges Sorel como ainda a publicação de escritos de Lev Trótski profundamente marcados (como os de Bukhárine e de Kautsky) por um materialismo rude, maquinal, 
maneceram agarrados, senão em princípio, pelo menos de facto.

Neste contexto, e acaso só neste, se deve por ventura entender a afirmação de Sérgio (S5) de que, se aceita com júbilo o destino de precursor autêntico do materialismo histórico nas nossas letras (não sem notar, aliás, e com justo motivo, que é esta opinião que não vai sem as maiores reservas e as mais minuciosas elucidações) pois é de todo inexacto o filiar nele a doutrina dos seus ensaios histórico-sociológicos e político-sociológicos, apesar de serem todos eles organizados em função dos problemas-chave da economia do País, sob o duplo aspecto do condicionamento económico-social e da consciente

automático e fatalista. Típicos do simplismo e do sectarismo teórico de então são ainda, por exemplo, certos artigos de G. Lukács, alguns dos quais reunidos em volume, em 1920, com o título Geschichte und Klassenbewusstsein. Como típico de desconhecimento total e de total incompreensão da concepção materialista da historia, por essa ocasião, nos meios universitários, aponte-se, entre outros, o confrangedor livrinho Matérialisme historique et interprétation économique de l'histoire, Paris, 1927, do historiador francês Henri Sée, autor que, no entanto, noutros trabalhos, dera provas de competência e de honestidade intelectual. Quanto a Portugal, nos últimos anos da República liberal, em matéria de marxismo, estava-se no período do ratesismo (do nome do dirigente operário Carlos Rates). Concluiremos então que a este modo rudimentar de imaginar a concepção materialista da história - e tão-só a ele, que não à exacta doutrina, - se podem reportar designadamente as alegações de Sérgio nos Ensaios, P, Coimbra, 1949, pp. 58-63. À margem das indicações que ficaram dadas, a traços largos, para balizar os quadros ideológicos em que ocorreram as intervenções histórico-sociológicas de Sẻrgio, talvez não seja despropositada, em contrapartida, uma indicação mais, como ponto de referência teórico e para uma mais consciente reflexão sobre o assunto. Em nosso entender, a melhor explanação sistemática do estado actual da temática e da problemática da concepção materialista da história, em toda a sua riqueza e complexidade, encontra-se em: Grundlagen des historischen Materialismus, obra colectiva sob a direcção de Erich Hahn, Dietz Verlag, Berlin, 1976; em Kategorien des historischen Materialismus. Studien zur Widerspiegelung gesellschaftlicher Entwicklungsprozesse in philosophischen Begriffen, hrsg. v. Nikolai Drjachlow, Ekkhard Lassow, Wladimir Rasin, Gottfried Stiehler, Dietz Verlag, Berlin, 1978, e em A. K. Uledow, Die Struktur des gesellschaftlichen Bewusstseins $^{2}$, hrsg., v. Werner Müller, Deutscher Verlag der Wissenschaften, Berlin, 1973. Uma obra não muito recente, mas de qualidade: D. I. Chesnokov, Materialismo Histórico, trad., E. Pueblos Unidos, Montevideo, 1966. Na mesma perspectiva teórica, mas incidindo porém na análise de problemas historiográficos e metodológicos precisos, ver História, Ciência Social, Prefácio, selecção e organização de Vasco de Magalhães-Vilhena, na colecção por nós dirigida «Dialéctica», vol. 6, Livros Horizonte, Lisboa, 1981.

(35) Por exemplo, nos Ensaios, V, Lisboa, 1936, pp. 300-301 e nas Notas de Esclarecimento, Porto, 1950, p. 52. 
finalidade económica das descobertas marítimas e das conquistas portuguesas.

E fora de dúvida, e sob mais de um aspecto, que as investigações de Sérgio neste domínio são por completo estranhas às categorias do materialismo histórico $\left({ }^{36}\right)$. Ele próprio o disse sem rodeios: «Em mim, as interpretações económicas dos aconteceres históricos não têm coisa alguma de materialistas; para mim, os sucessos resultam das ideias dos homens (embora ideias sobre vantagens económicas») $\left({ }^{37}\right)$. Ou ainda:

(") Se algumas dúvidas perduram a este respeito, atente-se no que Sérgio escreveu no Prefácio da segunda edição do primeiro tomo dos Ensaios, Coimbra, 1949, pp. 58-63; ver igualmente a nota (não assinada) que Sérgio apôs à tradução portuguesa de "O Programa Cooperatista", de Charles Gide, Seara Nova, XIV, n. ${ }^{\circ} 427$, Lisboa, 1935, p. 300; assim como o tomo V, dos Ensaios, Lisboa, 1936, pp. 300-301 e o tomo VIII, Lisboa, 1958, pp. 75-76, e as Notas de Esclarecimento, Porto, 1950, pp. 50-52. Importa registar a que cremos ser a sua mais antiga declaração sobre o assunto: «não há nada. nos meus escritos, do materialismo histórico de Carlos Marx», «Tréplica a Carlos Malheiro Dias sobre a Questão do Desejado», Seara Nova, n. ${ }^{\circ}$ 45-46, Lisboa, Maio de 1925, p. 173, e ainda Tréplica a Carlos Malheiro Dias sobre a Questão de O Desejado, ed. «Seara Nova», Lisboa, 1925, p. 57) retorquindo a Carlos Malheiro Dias que o declarara «seguidor do materialismo histórico de Marx» (ob. cit., pp. 54-55). Mas mais: Sérgio recorda ainda, noutra ocasião, e de esta feita a propósito de, nas Considerações Histórico-Pedagógicas, saídas do prelo em 1915, mas explanando ideias expostas verbalmente desde anos antes (cf. Ensaios, III'1, Porto, 1932, p. 287), ter proposto o problema e a hipótese a explorar e sustentado a teoria do fundamento burguês-mercador, marítimo, internacional, da nacionalidade portuguesa, e apresentado assim a formação de Portugal como um episódio do grande movimento comercial-marítimo, burguês, europeu, do século XI, afirmando o carácter marítimo e universalista da nação portuguesa desde a sua origem, observa Sérgio (em nota a um texto seu de Janeiro de 1925, no tomo II, dos seus Ensaios, em 1929, pp. 74 e 255 (esta nota foi curiosamente omitida da segunda edição de este tomo II, de 1957, mas retomada em Nota nas Obras Completas. Ensaios, II, Sá da Costa Editora, Lisboa, 1972, pp. 273-274; cf. Ensaios, 1932, p. 288) hipóteses que foram então recebidas com hostilidade e que o haviam repelido «como «materialista históricom"». Ademais, numa nota ao tomo $V$ dos Ensaios, Lisboa, 1936, pp. 300-301, mas igualmente suprimida na segunda edição de 1955 (cf. «Resposta a uma Consulta», Seara Nova, XVIII, n. ${ }^{\circ} 545$, pp. 390-391), Sérgio observa que em virtude do reconhecimento dos motivos económicos da acção guerreira (e em geral da acção política) dever notar que se tal ideia, de facto, domina a sua Historia de Portugal, da casa Labor, «a consideraram iniciadora do materialismo histórico entre nós». «Opinião esta - acrescenta - que demanda ressalvas, explicações, minúcias, não implica no entanto a aceitação de que a economia é uma injrastrutura (Unterbau) de que é superstrutura (Oberbau) a organização política, - de que a actividade económica é anterior, e serve de base, à organização política de uma sociedade.»

(3T) Ensaios, P, Atlântida, Coimbra, 1949, p. 60. 


\section{Idealismo Histórico-Social}

«O motor da evolução econòmica é o que 'está no pensamento como ideia', são as «forças intelectuais da produção» (S8).

Disse por isso Sérgio, com razão plena, que sugere interpretações económicas dos factos, mas não interpretações materialistas deles $\left({ }^{39}\right)$, pois é certo que se o movimento de interesse pela história económica tem vida e é em grandíssima parte suscitado pela concepção materialista da história, nem toda interpretação económica da história releva necessariamente do materialismo histórico. Longissimo disso; como fácil é constatar. De resto, ele mesmo o disse, o de que se convenceu «foi disto, e só disto: que as acções da política (da política, note-se: não me refiro às ciências, ou à filosofia, ou às artes) têm sido dominadas, na maioria dos casos, pela ideia de se conseguirem umas determinadas vantagens, a que cabe a designação de materiais-económicas, entendido este termo numa acepção bem larga» $\left({ }^{40}\right)$.

A filosofia implícita nos seus escritos de história sociológica é sempre de facto uma filosofia idealista.

Em Sérgio, o reconhecimento dos motivos económicos da acção guerreira, e em geral da acção política, é solidário da convicção que não se deve considerar a estrutura económica como anterior à política, mas sim como contemporânea e inseparável dela. Sérgio recusa as categorias de base económica e de superestrutura: o seu modo de ver não considera a actividade social económica como infraestrutura, de que a actividade social política fosse a superestrutura; vê-as a ambas como dois aspectos «contemporâneos», «interdependentes» (inseparáveis e correlativos): «são como matéria e forma de um processo único». Alega: se a estrutura jurídico-política é uma regulamentação da vida económica, a economia, por consequência, não pode preceder a estrutura política, não the pode servir de pedestal $\left({ }^{41}\right)$.

É porém convicção nossa que se esta tem sido sempre a teoria histórica de Sérgio, a sua análise concreta dos problemas históricos não poucas vezes inculca a noção contrária, e que é a seguinte: que a actividade económica é anterior, e serve de base, à organização política de uma sociedade. Ao

(3S) História de Portugal, I, Livraria Portugália, Lisboa, 1941, p. 242. (O grifado é de Sérgio).

(39) Notas de Esclarecimento, Porto, 1950, p. 22 ; cf. pp. 50-51.

(40) Ensaios, I², 1949, p. 59. (Os grifados são também de Sérgio).

(41) Ensaios, V, Lisboa, 1936, p. 301; «Resposta a uma Consulta», Seara Nova, XVIII, n. ${ }^{\circ}$ 545, Lisboa, 1938, pp. 390-391 (o sublinhado é de Sérgio). Cf. Ensaios, VIII, Lisboa, 1958, pp. 75-76. 


\section{Antonio Sérgio}

que supomos, foi por terem atentado mais na obra histórica de Sérgio, e sobretudo em certas partes déla desgarradas do conjunto, do que na sua teoria da historia que os leitores, em regra geral, foram levados a admitir — erroneamente, sem sombra de dúvida - que Sérgio aceitava os princípios do materialismo histórico. Além disso, a declaração de Sérgio nas Cartas de Problemática (42) de que era marxista (ou quase que era inteiramente marxista) no que é pertinente à crítica social-económica, ainda que o não fosse em «metafísica» nem em teoria do conhecimento, vinda depois daquela outra declaração bem conhecida, como vimos, de que se regozijava com o ser considerado o introdutor entre nós do materialismo histórico, e como que a reforçá-la, apesar de matizada, causou talvez indevidamente algumas confusões.

Se não estamos em erro, aquilo que levou sobretudo muitos dos leitores de Sérgio a ficar suspeitando de que, segundo ele como consoante a concepção materialista da história, a actividade económica é anterior e serve de base à organização política da sociedade e, também, que a luta que entre si travam as classes sociais tem sido e é a força determinante, o elemento motor da história em toda sociedade antagónica, isto é, em toda sociedade de classes, foi provavelmente a leitura, na obra de Sérgio, de textos como os três seguintes que transcrevemos.

Eis o primeiro, que nos ocorre:

«Poucos países há, certamente, em cuja história seja tão sensível, de ponta a ponta, o influxo do factor económico, como este nosso: poucos há, também, cuja história económica fosse tão desprezada; e será acaso dos maiores obstáculos ao ressurgimento da nossa Pátria a falta geral de conhecimentos sólidos das condições económicas em que evolucionou. Se algum mérito se pudesse achar nos ensaios históricos que delineei, seria decerto o de pôr em relevo o condicionamento económico dos nossos feitos, a dependência em que estiveram sempre das necessidades vitais da Europa inteira, e a consciente finalidade, o objectivo comercial, a científica execução das empresas de descobrimento» $\left({ }^{43}\right)$.

$\left.{ }^{(42}\right)$ Cartas de Problemática, Carta n. ${ }^{\circ}$, ed. Inquérito, Lisboa, 1952, p. 8.

(") Antologia dos Economistas Portugueses. Seleç̧ão, prefácio e notas. Século XVII. Obras em Português, Lisboa, 1924, pp. III-IV. Este o texto a que atrás aludimos e que tão forte impressão causou a Lúcio de Azevedo, como ele disse a Sérgio, e está na base da sua obra Épocas de Portugal Económico, Lisboa, 1929. 
Eis o segundo trecho:

«Los puertos eran más numerosos que ahora, y constituían escala inexcusable para la navegación entre el Norte y el Sur de Europa. De ahí provino, en el litoral, la formación de una burguesía cosmopolita, opuesta, en mentalidad y en intereses, a los señores rurales del interior. En nuestra opinión, la actividad de los puertos fué el mayor fundamento de la formación de la nacionalidad; los hallazgos más recientes de los eruditos confirman nuestra teoría. El antagonismo entre la burguesía comercial-marítima y los señores del interior tiene, como veremos, participación importantíssima en la evolución de la sociedad Es lo más probable que la influencia de los no indígenas - cruzados, comerciantes de los puertos... - contribuyese a evitar la incorporación política al Reino castellano-leonés, de esta faja occidental en donde el comercio del Norte de Europa podía encontrar al del Mediterráneo. Parece, pues, que la situación de los puertos utilizables, en número superior, como hemos dicho, a los que hoy existen, fué el factor geográfico más poderoso para la independencia de Portugal. La autonomia de la nación se apoyó en el mar y en la población heteróclita que le llegaba por allí. Desde los puertos fué organizada la reconquista y colonización del país .... En la Revolución burguesa de 1383-5 no fué engendrada solamente una dinastía nueva, mas también una proporción nueva entre la importancia de las clases sociales y su respectiva actividad económica, lo cual dió como resultado una fase nueva, precisamente característica de la historia de Portugal........ Cabe descubrir, ya originariamente, un cierto antagonismo entre la burguesía de los mercadores del litoral y la aristocracia proprietaria del hinterland.... Los problemas del comercio marítimo dominaron desde entonces a toda la política del país» $\left({ }^{44}\right)$.

Eis agora o terceiro trecho:

« .... A minha hipótese, não é em rigor, a de que a formação de Portugal se inicia como um incidente das lutas da Reconquista, para acabar como obra de uma burguesia de litoral, operosa e íntegra; a minha hipótese é, sim, a de que na formação de Portugal se nos revela, desde princípio, um elemento cosmopolita e comercial burguês, que toma completa consciência de si, e que se apossa por inteiro do gover-

O Historia de Portugal, Labor, Barcelona, 1929, pp. 26-27, 51-52. Cf. Ensaios, III, Porto, 1932, pp. 288-289. Ver na Breve Interpretação da História de Portugal, Obras Completas, Livraria Sá da Costa, Lisboa, 1972, pp. 6, 15-16, 33 e 34. 


\section{Antonio Sérgio}

no da grei, em 1383. Do século XI em diante, na Europa feudal, a riqueza criada pela faina agrícola suscita o aparecimento de uma economia nova, comercial e financeira. Desenvolvem-se as cidades, o grande comércio, a empreendedora finança; cria-se uma corrente de grande tráfico entre a Europa do Norte e o levante, corrente de que as Cruzadas são uma parcela, um elemento, um aspecto. Pois bem: essa corrente de actividade, europeia e comercial-marítima, incidindo desde o seu início na costa atlântica da península ibérica, deu esteio à independência do nosso país. Ligar as origens de Portugal, pois, ao próprio nascimento da burguesia europeia, - tal é a hipótese que eu propus» $\left({ }^{45}\right)$.

Note-se que estes textos não são acidentais nos ensaios históricos que Sérgio delineou. Não é, pois, de surpreender que o leitor, pouco habituado, antes da obra de Sérgio, a que lhe falassem da história portuguesa nestes termos, tivesse sobretudo. retido o que Sérgio escrevera acerca do «imperativo económico», da «importância do condicionamento económico», do «influxo do factor económico» na vida política $\left({ }^{46}\right)$, e outrossim na educação e na cultura. Com efeito, nas Considerações Histórico-Pedagógicas, Porto, 1915, pp. 42-43, escreveu ele assim:

«A verdadeira cultura anda adstrita às necessidades da produção, e essas necessidades não as tinha o Portugal brasileiro, que com o oiro das suas minas adquiria os produtos da indústria alheia. Era sim o regime económico quem

nos punha fora das circunstâncias de fazer os mínimos progressos........ Com a sua lucidez habitual, ensinou Herculano

que a educação portuguesa é dependência, como não podia deixar de ser, da organização económica da sociedade portuguesa». E depois de uma significativa citação de Herculano em que se diz que para a grande indústria portuguesa de então (a qual consistia em devorar as entranhas - as minas - do Brasil, Sérgio remata: «Eis bem clara a ideia de que a cultura é função da indústria nacional» $\left({ }^{47}\right)$.

Mais: no artigo citado há pouco: «Em torno de um livrinho», de grande importância para a compreensão do pensamento histórico de Sérgio, lê-se ainda o seguinte:

«Há um enlace lógico natural entre a forma de activi-

(45) «Em Torno de Um Livrinho», Seara Nova, IX, n. ${ }^{\circ}$ 201, Lisboa, 1930, p. 140.

(46) Cf. Ensaios, IJ Coimbra, 1949, pp. 51-52.

(47) Considerações Histórico-Pedagógicas, Porto, 1915, pp. 42-43. 
dade econòmica de um povo (ou de uma classe) $\mathrm{e}$ as suas tendências filosófico-político-religiosas» $\left({ }^{48}\right)$.

De tudo isto, possivelmente, decorre que não poucos dos leitores de Sérgio tivessem interpretado mal os seus pressupostos filosóficos. Acaso não seja exclusivamente por isso.

Alguns até, não discutindo o fundo exacto do problema, julgavam ver na obra de Sérgio uma contradição entre um materialismo histórico implícito na sua prática histórica, e uma orientação filosófica geral idealista no atinente à sua teorização historiográfica. Não se apercebiam de que a partir das posições gnoseológicas basilares do seu idealismo crítico, Sérgio repelia, coerentemente, e sem a menor ambiguidade, a tese epistemologica fundamental do materialismo histórico; a saber, que a consciência dos homens não determina o seu ser, antes muito ao contrário, o ser social determina a sua consciência. Não é caso de nos perguntarmos com surpresa como pôde ter sido tomado por um adepto da teoria dialéctica materialista da história quem sempre afirmou resolutamente recusar a teoria dialéctica materialista do conhecimento, isto é, a teoria do reflexo?

O que cremos possível afirmar em verdade é que António Sérgio combateu sempre com extremo vigor a maioria das teses fundamentais do materialismo histórico e as suas noções de base, a começar pela categoria de forças produtivas. Cumpre salientar, todavia, que, por via de regra, a sua crítica é dirigida mais contra o que alguns escritores menores disseram do que propriamente contra o que sempre afirmaram os mais autorizados teorizadores.

Ao que julgamos provável, admoestando os que ele apelida de «fideistas do materialismo histórico absoluto, ultra-dogmático, a cem por cento» ( $\left.{ }^{49}\right)$, Sérgio, em regra, parece querer visar menos a teoria mesma do que aqueles dogmáticos de hoje em tudo análogos àqueles outros dogmáticos franceses dos anos 70 que, segundo o testemunho de Engels, levaram Marx certo dia a dizer: "Tout ce que je sais, c'est aue je ne suis pas marxiste» $\left({ }^{50}\right)$. Como quer que seja, contra esses,

(") «Em Torno de Um Livrinho», Seara Nova, IX, n. ${ }^{\circ}$ 201, Lisboa, 1930. p. 141 (cf. Ensaios, III, Porto, 1932, p. 291).

(") Por exemplo, nos Ensaios, P, Coimbra, 1949, pp. 59-60 e 62, e na História de Portugal, I: Introdução Geográfica, Lisboa, 1941, pp. 241-242.

(") A intenção irónica e alusiva da frase de Marx evocada por Engels, e o pròprio facto de ter sido pronunciada em francês são explicitados e sugeridos na carta de Engels a C. Schmidt de 5-VIII-1890: K. Marx-F. Engels, Ausgewählte Briefe, Berlin, 1953, p. 500 $=M E W$, Bd. 37, Berlin, 1967, p.436. Além, claro, da por vezes mencionada carta de 
e tão só contra esses, que não contra a doutrina genuína, investe, bem ao cabo de contas, a argumentação de Sérgio. Porém, a linha do raciocínio, na grandíssima maioria do casos, é realmente susceptível de deixar a confusão no espírito do leitor que não leia atento ou esteja mal informado, - o que Sérgio decerto não buscava. Ao que julgamos plausível, cláusulas de estilo (como a que acima citámos ou, como estoutra: o «que é uso exporem os que se dão como adeptos do 'materialismo histórico'» (51), não bastam de per si para dissipar a confusão. Muito ao contrário. Ainda mesmo que só «dos que se apresentam como 'materialistas históricos'» (B2), tivesse tido Sérgio que se ocupar ao debater pontos de interpretação da história portuguesa. Numa passagem da sua obra, pelo menos, e sem atenuações de estilo, sem sombra de reserva, Sérgio atribui à própria «doutrina dos autores de $A$ Sagrada Família» e não já à distorção que dela fizeram uns tantos aue se diziam seus sequazes, princípios filosóficos que os autores sempre energicamente repeliram. A saber: o empirismo, a noção de «uma realidade absolutamente dada» ( ${ }^{53}$ ). Mas não só isso. Assim, ao criticar a categoria de forças produtivas, nos numerosos passos em que a ela se refere, Sérgio não tem em conta precisamente que, nas palavras mesmas de Marx, «les forces productives sont le résultat de l'énergie pratique des hommes» ${ }^{54}$ ) e que é, por conseguinte, sem sentido, cabalmente despropositado, o pretender-se que o materialista em historia fala em crescimento e desenvolvimento fatal e automático, mecánico, das forças produtivas como se fossem as próprias forças que se desenvolvessem e evoluíssem e como se fossem produtivas por si mesmas. Ora, assim objectando, Sérgio não toma em conta na verdade que, inteiramente ao contrário do que afirma, o enriquecimento da esfera intelectual da actividade humana constitui o factor fundamen-

Engels a Ed. Bernstein de 2/3 - XI - 1882, na qual Engels assevera textualmente «dass Marx dem Lafargue sagte: 'ce qu'il y a de certain c'est que moi, je ne suis pas marxiste'» (MEW, Bd. 35, 1967, p. 388; cf. pp. 386-390).

(51) «Explicação e Subsunção sob Formulas Gerais», Aqui $e$ Além, Revista de divulgação cultural, n. ${ }^{\circ}$ 3, Lisboa, 1945, p. 21. cf. p. 3 .

(") Ibidem.

O Cartas de Problemática, Carta n. ${ }^{\circ}$ 10, Lisboa, 1954, p. 2;

(M) Carta de Marx a P. V. Annenkov, de 28-XII-1846, em polémica com Proudhon. Original francês em Marx-Engels, Briefe über "Das Kapital", Berlin, 1954, p. 19; versão alemã in ob. cit., p. 29 e $M E W$, Bd. 27, Berlin, 1963, p. 452; «Die Produktivkräfte sind also das Resultat der angewandten Energie der Menschen». 
tal do desenvolvimento das forças produtivas, que as forças produtivas não só compreendem os meios de produção criados pela sociedade, e primeiro que tudo os instrumentos de trabalho com os quais se produzem os bens materiais, como compreendem ainda e sobretudo os homens que, com a sua experiência e a sua perícia, com a sua técnica e a sua ciência, produzem esses bens materiais.

Argumentar contra o materialismo histórico (como faz Sérgio) para dizer que a matéria-prima não existe como tal simplesmente na natureza mas que é um produto do trabalho, não tem sentido, pois, como se sabe, foi muito precisamente Marx quem disse, no Livro I de O Capital, que as matérias-primas são um produto do trabalho e que são precisos os homens para que elas possam desempenhar o papel de matérias-primas: as condições naturais só se convertem num elemento do ser social quando os homens utilizam os objectos naturais e as forças da natureza como meios de produção. Ora, isto, mesmo um autor como N. Bukhárine (que tem do desenvolvimento das forças produtivas, e, de uma maneira geral, do materialismo histórico uma concepção demasiado estreita) havia posto claramente em evidência num livro célebre que Sérgio não podia deixar de conhecer ${ }^{55}$ ). Abordando, por exemplo, a questão de saber como se resolve «a contradição entre a evolução das forças produtivas e a base económica da sociedade», o referido autor escreve, consoante se lê na citada tradução francesa, a mais difundida por esse então em Portugal: «Il va de soi que ce conflit a toujours été résolu par les hommes, et ce, au moyen d'une cruelle bataille de classes» (B6). Ai está: «toujours par les hommes» — «il va de soi»!.

Ainda mais. «Pensar em evolução das forças de produção, materialisticamente» $\left({ }^{57}\right)$, contrariamente ao que Sérgio quer supôr tomando por materialismo histórico o que não passa de uma sua caricatura, - quaisquer que sejam os autores da caricatura, - não significa de modo algum admitir «que os sucessos históricos os houvesse determinado uma evolução das coisast de realidades materiais independentes da psique» $\left.{ }^{58}\right)$.

António Sérgio redigiu este passo do Prefácio da segunda edição do primeiro tomo dos Ensaios em 1949. Ora, se nos

(K) Referimo-nos, é claro, à Théorie du matérialisme historique, trad. E. S. I., Paris, 1927, por exemplo, p. 123.

khárine, quem sublinha "par les hommes».

(") Ensaios, I², Coimbra, 1949, p. 59.

(“) Ob. cit., p. 58. 
reportarmos a um escrito de J. Stàiine que, dada a sua reputação- é inclusivamente citado no Vocabulaire technique et critique de philosophie $e^{5}$ publicado pela «Société française de Philosophie» sobre a direcção de A. Lalande, Paris, 1947, pp. 1226-1228 - Sérgio obviamente não podia desconhecer. O que aí lemos é, na tradução francesa, textualmente o seguinte: «Les instruments de production à l'aide desquels les biens matériels sont produits, les hommes qui manient ces instruments de production et produisent les biens matériels grâce à une certaine expérience de la production et à des habitudes de travail, voilà les éléments qui, pris tous ensemble, constituent les forces productives de la société.

Mais les forces productives ne sont qu'un aspect de la production, un aspect du mode de production, celui qui exprime le comportement des hommes à l'égard des objets et des forces de la nature dont ils se servent pour produire des biens matériels. L'autre aspect de la production, l'autre aspect du mode de production, ce sont les rapports des hommes entre eux dans le processus de la production, les rapports de production entre les hommes. Dans leur lutte avec la nature qu'ils exploitent pour produire les biens matériels, ${ }^{1}{ }_{\gg}$ les hommes ne sont pas isolés les uns des autres, ne sont pas des individus détachés les uns des autres; ils produisent en commun, par groupes, par associations. C'est pourquoi la production est toujours, et quelles que soient les conditions, une production sociale....... Mais quel que soit le caractère que revêtent les rapports de production, ceux-ci sont toujours, sous tous les les régimes, un élément indispensable de la production, à l'égal des forces productives de la société.................... Il suit de là que la production, le mode de production englobe tout aussi bien les forces productives de la société que les rapports de production entre les hommes, et est ainsi l'incarnation de leur unité dans le processus de production des biens matériels. Cela veut dire que l'histoire du développement de la société est, avant tout, l'histoire du développement de la production, l'histoire des modes de production qui se succèdent à travers les siècles, l'histoire du développement des forces productives et des rapports de production entre les hommes.

Par conséquent, l'histoire du développement social est, en même temps, l'histoire des producteurs des biens matériels, l'histoire des masses laborieuses qui sont les forces fondamentales $\mathrm{du}$ processus de production et produisent les biens matériels nécessaires à l'existence de la société.

Par conséquent, la science historique, si elle veut être une science véritable .... doit avant tout s'occuper de l'his- 


\section{Idealismo Histórico-Social}

toire des producteurs des biens matériels, de l'histoire des masses laborieuses, de l'histoire des peuples» ${ }^{(59)}$.

Porém, vejamos, de perto as razões de Sérgio.

Criticando o papel que, para o materialismo histórico, ocupa a categoría de «forças produtivas» na explicação histórica do processo social, Sérgio objecta que se é materialista quando se fala em «evolução das forças de produção» como se fossem as próprias forças que evoluíssem e como se fossem produtivas por si mesmas, mas que ele, Sérgio, nunca admitiu que os sucessos históricos os houvesse determinado uma evolução das coisas, de realidades materiais independentes da psique, e das quais as ideias fossem só reflexos. O de que se convenceu (acrescenta para bem marcar no tangente a este ponto quanto as suas interpretações económicas dos aconteceres históricos nada têm de materialistas) foi que no quadro interpretativo que concebe dos factos que têm sido apontados no acontecer histórico pelos que se chamam a si mesmos «materialistas históricos», não podem surpreender-se quaisquer feições a que convenha o epíteto de «materialistas». $\mathrm{Na}$ sua maneira de ver, e ao revés do que ele estima ser a concepção materialista da história, «das maneiras como se põem a uso, para benefício económico dos seres humanos, as forças que existem na natureza, resultam mutações no modo de ser do social, mas sendo que as transformações que têm ido ocorrendo nas maneiras como o homem sabe tirar proveito das forças que encontra na natureza ambiente (como a força muscular dos animais e dos homens, a da água corrente, a dos ventos que sopram, a da combustão do carvão, do petróleo, etc.) não procede de modificações materiais dessas forças, mas de novas ideias da mente inventiva àcerca da maneira de as aproveitar. Não existem forças de produção em si: as forças que existem só produzem algo quando o homem tem a ideia de as fazer produzir e as põe ao serviço da sua ideia. Para mim, pensar em evolução das forças de produção, materialisticamente, é tomar a sério um palavreado péssimo», diz ainda. E logo depois: «Não foi a água do moinho de água que se mudou em água de central eléctrica, por evolução material dessa mesma água, por metamorfose espontânea da substância aquosa: foi sim o espírito que criou o dínamo (mais exactamente: que criou as ideias de que resultaram os dínamos)

${ }^{(59)}$ J. Staline, Le Matérialisme dialectique et le matérialisme historique, nouv. ed., Paris, 1945, pp. 21-22 (Os itálicos não são nossos mas do autor). A primeira tradução francesa é de 1939. 
e também a ideia do movimentar o dinamo pela corrente de uma água que é sempre a mesma» $\left({ }^{60}\right)$.

Ora, formulando assim a sua objecção, Sérgio passa precisamente em silêncio que Marx, como se deve saber, distinguia as forças produtivas objectivas $\mathrm{e}$ as forças produtivas subjectivas, e que estas, segundo ele, se manifestam como propriedades dos indivíduos (61). Mais: que Marx não separa a força do conhecimento dos esforços físicos do homem, os quais são também um componente relevante das forças produtivas subjectivas. Na verdade, o homem, como disse Marx, não pode actuar sobre a natureza sem pôr em movimento os seus próprios músculos, sob o controlo do seu próprio cérebro: da mesma maneira que na natureza mesmo o cérebro e as mãos pertencem a um só organismo, assim também no processo do trabalho, o trabalho intelectual e o trabalho físico estão ligados (62). Assim, no processo do trabalho, o homem utiliza os resultados dos conhecimentos adquiridos e acumulados sob a forma da experiência, de hábitos de produção e de ideias científicas. Os elementos materiais das forças produtivas não podem ser utilizados independentemente da acção que a experiência e a ciência exercem sobre eles: os produtos da actividade humana são, consoante as palavras bem sabidas de Marx, a força materializada do conhecimento que se desenvolve, o fito da actividade produtiva do homem consistindo na utilização das forças da natureza, na transformação de processos naturais em processos industriais. É neste sentido também que se deve compreender a indicação de Marx de que o desenvolvimento do capital fixo mostra até que ponto o conhecimento social geral se converteu numa força produtiva directa e, por conseguinte, as condições do próprio processo social da vida foram submetidas ao controlo da inteligência

$\left.{ }^{(60}\right)$ A. Sérgio, Ensaios, I ${ }^{2}$ Coimbra, 1949, pp. 58-60, 62. - Já que Sérgio acerca da noção de forças produtivas evoca o caso do moinho de água, veja-se o importante estudo de Charles Parain: «Rapports de production et développement des forces productives: l'exemple du moulin à eau», La Pensée, n. ${ }^{\circ} 119$, Paris, 1965, pp. 55-70. Pela leitura deste belo estudo de um reputado especialista poderá ver-se sem dificuldade como a argumentação de Sérgio está, sobre este ponto, inteiramente fora do assunto.

(el) Ver, por exemplo, K. Marx, Formen, die der kapitalistischen Produktion vorhergehn (über den Prozess, der der Bildung des Kapitalverhältnisses oder der ursprünglichen Akumulation vorhergeht), in Grundrisse der Kritik der Politischen Ökonomie (Rohentwurf) 1857$-1858^{2}$, Berlin 1953, pp. 375 e ss.; Pre-capitalist Economic Formations, Edited and with an Introduction by Eric J. Hobsbawm, London, 1964. $\left(\AA^{2}\right)$ K. Marx, Das Kapital, vol. 1, Berlin, 1953, p. 533. 
e por ela transformadas (63). É a utilização necessária da ciência na produção que faz dela uma força produtiva directa da sociedade, sobretudo, claro, depois que a máquina-utensílio («machine-outil») modificando a relação homem-instrumento inaugurou a revolução industrial dos fins do século XVIII e começos do século XIX.

Sérgio, ao que nos parece verosímil supôr, tem aqui manifestamente em vista um texto de $O$ Capital, citado por Sorel (num dos escritos que mais contribuíram certamente, entre os leitores que não estudaram Marx, a dar uma visão totalmente falsa do materialismo histórico (64)), em que se diz na versão dada por Sorel $\left({ }^{65}\right)$ - que «le mouvement spontané (auf die naturwürchsige Gestalt ihres Produktionsprocesses) est un fruit aussi naturel (eben so sehr ein nothwendiges Produkt) de la grande industrie que les chemins de fer, les machines automates et le télégraphe électrique». Ora, basta integrar este passo no seu contexto (ou até simplesmente aproximá-lo daqueles outros, que citamos, de Marx, relativos à sua concepção de forças produtivas, num dos quais se alude precisamente às locomotivas e ao telégrafo e se diz que as forças naturais só intervêm no processo social quando submetidas à acção dos homens) para se ver sem dificuldade que o passo de $O$ Capital há pouco transcrito significa coisa muito diferente do que o que inculca Sorel, ao citá-lo. De resto, bastava

(63) Marx, Grundrisse der Kritik der Politischen Ökonomie (Rohentwurf) 1857-1858, Dietz, Berlin, 1953, p. 594.

(«4) Trata-se da Préface de Georges Sorel (a que já nos referimos) à edição francesa do livro deformante de Edwin R.-A. Seligman, L'Interprétation économique de l'histoire, Paris, 1911, pp. I-XXX. Foi em larga medida através deste prefácio que nos países latinos se radicaram em muitos dos que nunca estudaram as obras de Marx e Engels como se estudam as de Platão, de Descartes, de Galileu, de Kant ou de qualquer outro dos vultos marcantes da história do pensamento (isto é: nos textos das melhores edições e de ponta a ponta, acompanhando essa leitura atenta da consulta dos melhores comentários e estudos críticos. Nunca leu Marx quem só o leu na versão horripilante das edições Costes, de Paris, como nunca leu Hegel quem como durante anos pelo menos Antero, segundo a sua própria confissão - só o leu na versão francesa mais ou menos fantasista de Vera) ; foi em larga medida através deste prefácio de Sorel, dizíamos, que se radicaram no espírito dos que nunca leram Marx como ele deve ser lido, i.e. como deve ser lido qualquer pensador de vulto, as extravagantes ideias, sem fundamento real, segundo as quais Marx se propusera «construir uma filosofia da história» (p. IV) e que a noção de «catástrofe» (pp. II-III, IX, XXI) desempenhava nele um papel importante. Ora, o facto é que desde um ponto de vista científico, Marx e Engels tanto impugnaram a «filosofia da história» como a «filosofia da natureza».

(") G. Sorel, ob. eit, pp. XVII-XVIII. 
atentar na expressão «aussi naturel.... que» para se ver mediatamente que sendo a grande indústria, como é óbvio, obra dos homens, falar de «movimento espontâneo» da sociedade não pode, no contexto, querer significar por forma alguma que o movimento social, que o processo histórico se realize sem a participação activíssima e consciente dos homens. Que poderia ser uma sociedade, um movimento social sem homens? Quando se entende porque não é o materialismo histórico um determinismo económico, quando se entende porque é o materialismo histórico um materialismo, quando se entende o que significa a categoria de matéria para a dialéctica materialista da sociedade, entende-se sem dificuldades o que pode, na concepção marxengelsiana, significar $o$ falar-se de movimento espontâneo no processo social. É «espontâneo» o movimento social que se processa objectivamente, independentemente das vontades individuais dos seus participantes, e da consciência que esses homens, ao agirem, têm do conjunto do processo social no qual participam. $\mathrm{O}$ comerciante que vende os seus produtos num mercado não tem por esse facto necessariamente consciência do mecanismo económico do mercado; que numa dada formação económico-social os homens entrem em relação como seres conscientes, não significa isso que as relações sociais que se estabelecem entre eles e que as leis a que está sujeito o desenvolvimento dessas relações estão determinadas também pela sua consciência; o soldado que participa numa batalha desconhece em princípio os planos do estado-maior relativos ao desenrolar das operações e os objectivos políticos, económicos, etc., que essa batalha pode ou mesmo visa servir, e os que efectivamente, objectivamente, virão a servir numa perspectiva histórica mais ampla, queiram-no ou não, tenham ou não tenham disso consciência os seus participantes. O não reconhecimento deste aspecto fundamental do processo social é, em nossa convicção, uma das fraquezas essenciais de toda a concepção idealista da história.

Nada menos exacto, a nosso ver, do que a opinião de Croce e de Sorel de que esta «terminologia» seja inútil ou favoreça os equívocos. Os equívocos resultam unicamente do desconhecimento da doutrina que criticam ou do seu propósito inequívoco de a desfigurar. Assim, ao citar (pp. XX-XXI) um passo de Marx onde figura a palavra alemã Notwendigkeit, traduzindo-a por «fatalidade», Sorel é inteligente e culto mais do que o bastante para saber que está deliberadamente falsificando a teoria que diz expor e que intenta criticar. No texto em questão Notwendigkeit significa e não pode significar outra coisa senão necessidade. Mas nunca, em caso algum, "fatalidade». Não the faremos a injúria de supôr que ele desconhe- 


\section{Idealismo Histórico-Social}

cesse a diferença radicai entre as duas. «Fatalité» - em alemão Fatalität - refere-se ao decreto inelutável de uma causa primeira (acção divina ou providência) e sublinha a impotência da vontade e da inteligência humanas para dirigir o curso dos acontecimentos, o qual se desenrola em despeito de todo desejo, pressão e esforço em contrário. Em ciência, fala-se de «necessidade», de «causalidade», de «determinismo», mas não de «fatalidade» ou de «fatalismo» $\left({ }^{66}\right)$.

Uma concepção científica da história que se propõe precisamente dar uma interpretação correcta do processo histórico e das forças sociais que o impulsionam não separa o curso da história das acções dos homens, da capacidade das massas; reconhecendo o carácter objectivo das leis que regem $o$ desenvolvimento social faz ressaltar muito precisamente, com particular evidência, que a história da sociedade a fazem os homens dotados de consciência e de vontade, mas actuando em condições concretas particulares em conjunturas determinadas. A acção humana criadora, a actividade política social dos homens integra a necessidade, a necessidade histórico-social ao revés da necessidade natural, é ela mesma obra dos homens.

Ora, o facto é que o materialismo histórico nunca estabeleceu uma contraposição entre o carácter objectivo, sujeito a leis, do desenvolvimento da história e a actividade dos homens. Foi o reformista e revisionista Bernstein, antimaterialista convicto, precisamente, quem propôs que se substituisse a denominação de «concepção materialista dialéctica da história» por «interpretação económica da história». Expressão, de resto, que serviu de título ao livro deformante de Edwin R.-A. Seligman (New York, 1902; Paris, 1911), que apesar disso, ou por isso mesmo, prefaciado em francês - e de que maneira!-por Georges Sorel (o inspirador de Mussolini), obteve larga difusão. Por sua banda, Achille Loria, num texto em que transluz a mesma incompreensão propusera que se desse à teoria o nome de «economismo histórico» (6T). Mas prossigamos.

A concepção materialista da história, longe de ignorar ou até de minimizar o «potencial espiritual» das ciências na expansão das forças produtivas dá-lhe, pelo contrário, um acentuado realce. Assevera: muito mais do que simples forças

(") Para outros pormenores, ver, por exemplo, o Vocabulaire technique et critique de Philosophie, de André Lalande, s.v. «Fatalité» $\mathrm{e}$ «Fatalisme».

(6I) Achille Loria, Sociologia, 1901, p. 192. 


\section{Antonio Sérgio}

naturais, as forças produtivas nas sociedades evoluídas são, no essencial, produtos da actividade humana ou, para que assim digamos, inteligência humana objectivada, força ou potência de conhecimento materializada ( $\left.{ }^{68}\right)$. O que não é de modo algum incompatível com a tese fundamental relativa à importância decisiva do modo de produção na vida da sociedade, e à dependência das relações políticas e ideológicas face ao modo de produção.

A concepção materialista da história está longe, longissimo, de reduzir-se à constatação de que a superestrutura política e ideológica depende da infraestrutura, mesmo tendo em conta - contra a «teoria» do «materialismo económico» vulgar e primário - que é inconcebível toda dependência unilateral de todos os fenómenos sociais ao chamado (simplistamente) «facto económico», que é inconcebível pensar-se que a infraestrutura económica determinaria $o$ conjunto das relações económicas ao passo que a política e a ideologia seriam meros resultados espontâneos, passivos, do movimento económico.

A «fatalidade» do desenvolvimento das forças produtivas é uma ideia de Bakúnine, por exemplo, mas não dos seus dois mais célebres antagonistas. Ideia repetida aliás mais tarde pelos ideólogos anti-marxistas e revisionistas da social-democracia, mas que tendo começado a manifestar-se (numa mistura incongruente de idealismo e de materialismo vulgar) nos anos 85-95 do século XIX, dera lugar, como é sabido, a certeiras réplicas. Definindo o papel da superestrutura política e ideológica na sociedade e a sua relação com a base económica, e concretizando o papel activo da superestrutura e a sua «acção em retorno» sobre a infraestrutura económica, as referidas réplicas punham ao mesmo tempo em plena evidência, inequivocamente, a independência relativa das diversas formas da superestrutura e designadamente da consciência social, precisando que se há casos em que as ideias retardam em relação ao real, outros há em que ideais estão, pelo contrário, em avanço sobre a realidade $\left({ }^{69}\right)$.

(") Cf. K. Marx, Grundrisse der Kritik der politischen Ökonomie (Rohentwurf) 1857-1858, Berlin, 1953, p. 594.

(e») $p_{\text {ara } 0} q_{U e}$ precede, o locus classicus são as cartas de Engels da última dezena de anos da sua vida: Marx-Engels, Ausgewählte Briefe, Dietz, Berlin, 1953; = MEW, Bd. 37, Dietz, Berlin, 1967; algumas de essas cartas em trad, inglesa em Marx-Engels, Selected Correspondence, Progress Publishers, Moscow, 1975. Mas altamente esclarecedora a este respeito é a parte final da carta de Marx a Friedrich Boite, de 23 de Novembro de 1871, que transcrevemos noutro lugar, e atinente às relações do politico e do econòmico: Ausgewählte 


\section{Idealismo Histórico-Social}

E porque assim é, se tem dito que o incremento das forças produtivas da sociedade não significa apenas $o$ aumento numérico dos bens materiais, mas também o próprio desenvolvimento progressivo da personalidade humana. $\mathrm{E}$ isto mesmo na medida precisamente em que os homens se libertam cada vez mais do império das forças espontâneas da natureza e da sua sujeição às forças espontâneas do desenvolvimento social. Sempre consoante esta tese, o desenvolvimento progressivo das forças produtivas e o desenvolvimento da personalidade humana não são de nenhum modo dois processos distintos. Há entre ambos uma relação dialéctica - mas o primeiro é, em definitivo, condição do segundo. As relações sociais estão intimamente vinculadas às forças produtivas. Nas sociedades antagónicas, o antagonismo das classes é factor decisivo para o desenvolvimento das forças produtivas. É pois erróneo conceber os progressos da técnica à margem e fora do quadro das relações sociais. O nível da técnica depende efectivamente da estrutura da sociedade: é ela em definitivo que favorece ou obstrui a sua progressão. São pois os quadros da estrutura social, a um tempo materiais e ideológicos, que decidem em última instância da estagnação, do retrocesso ou do avanço da ciência e das técnicas $\left({ }^{70}\right)$.

Entre os elementos que constituem principalmente as forças produtivas, Marx cita «o estado geral da ciência e o seu grau de aplicação tecnológico» - «die Entwicklungsstufe der Wissenschaft und ihrer technologischen Anwendbarkeit», - o nivel de todas as aplicações práticas por meio das quais a ciência compele as forças da natureza a submeterem-se ao

Briefe, Berlin, 1953, pp. 318-319 = Ausgewählte Schriften, Bd. 2, Dietz, Berlin, 1955, pp. 438-439; = MEW, Bd. 33. Dietz, Berlin, 1966, pp. 332-333; Correspondencia, Buenos Aires, 1957, pp. 214-215; Selected Correspondance, Moscow, 1975, pp. 254-255. - Acerca da famosa «última instância» (in letzter Instanz) a que se refere Engels na sua carta a Joseph Bloch, de 21 de Setembro de 1890, cf. o penetrante esclarecimento de Guy Besse en «Deux Questions sur un article», La Pensée, n. ${ }^{\circ}$ 107, Paris, 1963, esp. pp. 60-62.

(,0) A este respeito, veja-se a análise de um caso histórico concreto: Vasco de Magalhães-Vilhena «Progrès technique et blocage social dans la Cité antique. Esquisse de quelques problèmes», La Pensée, n. ${ }^{\circ}$ 102, Paris, 1962, pp. 103-120 e «Essor cientifique et technique et obstacles sociaux à la fin de l'antiquité», Les Cahiers du CERM, n..$^{\circ} 42$, Paris, 1965. Estes trabalhos são retomados e completados em «Surto Técnico e Científico e «Blocagem Social» na Cidade Antiga. Esboço de Alguns Problemas» e «Da Ideia de Progresso na Antiguidade», Antigos e Modernos. Estudos de História Social das Ideias, Livros Horizonte, Lisboa, 1983. 


\section{Antonio Sérgio}

trabalho $\left({ }^{\mathrm{n}}\right)$. Os instrumentos de trabalho, ou seja essencialmente o conjunto da técnica: máquinas e utensílios, a saber todas estas coisas que, nas palavras mesmas de Marx, são afinal «produtos da indústria humana,... órgãos do cérebro humano criados pela mão do homem; são, numa palavra, a força materializada do conhecimento»: «Sie sind Produkte der menschlichen Industrie .... Sie sind von der menschlichen Hand geschaffne Organe des menschlichen Hirns; vergegenständlichte Wissenskraft» $\left({ }^{72}\right)$.

Contrariamente ao que os leitores dessas críticas de Sérgio podem ter ficado a pensar, a concepção materialista da história não reduz as forças produtivas às meras forças naturais, isto é: àquelas forças que não são produto do trabalho humano. Para esta concepção, a utilização dos agentes naturais «coincide com o desenvolvimento da ciência como factor autónomo do processo de produção. Quando o processo de produção se torna uma aplicação da ciência, a ciência inversamente converte-se num factor ou, digamos assim, numa função do processo de produção» (73). Com efeito, muito ao inverso do que as objecções de Sérgio inculcam, Marx qualifica o próprio processo de produção de «ciência experimental, de ciência material e criadora, incarnando-se nos objectos»: «...Experimentalwissenschaft, materiell schöpferische und sich vergegenständlichende Wissenschaft...» ( $\left.{ }^{74}\right) . \quad 0$ grau de desenvolvimento dos instrumentos de trabalho indica exactamente, segundo esta concepção, a medida em que os conhecimentos sociais, a ciência em geral numa palavra, se converteram em forças produtivas. Ademais do seu conteúdo material, a produção $\mathrm{e}$ as forças produtivas comportam também um potencial espiritual. Produzindo, o homem produz-se a si próprio. Fundada na unidade da prática e da teoria, a his-

(") Ver: Das Kapital. Kritik der politischen Ökonomie, in Marx-Engels Werke, Bd. 23, Berlin, 1962, p. 54. Cf. Le Capital, Livre premier, trad, entièrement révisée par l'auteur, t.l., Ed. Sociales, Paris, 1948, p. 55: «....la force productive du travail .... dépend de circonstances diverses, entre autres de l'habileté moyenne des travailleurs; du développement de la science et du degré de son application technologique; des combinaisons sociales de la production; de l'etendu et de l'efficacité des moyens de produire et des conditions purement naturelles».

(") Grundrisse der Kritik der politischen Ökonomie (Rohenxvurf) 1857-1858, 2, Dietz, Berlin, 1953, p. 594.

(") «Un Inédit de Marx sur la Science», La Nouvelle critique, $X, .^{\circ}$ 100, Paris, 1958, p. 11. Cf. "Cuadernos de Cultura», IX, n. ${ }^{\circ} 4$, Buenos Aires, 1959, p. 78.

(14) Grundrisse der Kritik der politischen Ökonomie (RohenXwurf) 1857-1858। Berlin, 1953, pp. 599-600. 


\section{Idealismo Histórico-Social}

tória do trabalho é a história do desenvolvimento intelectual do homem. A ciência mesma é força produtiva. Mais ainda: numa sociedade desembaraçada das contradições antagónicas, ou em vias de isso, a ciência é força produtiva directa ( $\left.{ }^{75}\right)$.

Nada disto, como se estará advertindo, tomam em consideração as alegações de Sérgio. Tão pouco para essa sua crítica, ao que vemos, entram em linha de conta as relações entre as categorias de «forças produtivas», «relações de produção» e «modo de produção».

Ora, a dialéctica das forças produtivas e das relações de produção - revelada e formulada pela primeira vez em $A$ Ideologia Alemã — constitui justamente a mais importante descoberta científica que se encontra nesta obra; foi esta descoberta muito precisamente que contribuiu em grandíssima parte para a elaboração da concepção materialista da história como uma concepção geral $\left({ }^{76}\right)$.

Assim, a crítica de Sérgio à concepção materialista da história descura o facto de que ao acentuar o carácter espiritual específico da ciência, Marx a designa ao mesmo tempo como uma força produtiva universal $\left({ }^{77}\right)$. Ora descurando este facto capital, não tomando em linha de conta a destrinça primordial para a concepção dialéctica materialista da história de forças produtivas materiais e de forças produtivas humanas, não materiais, e seu condicionamento recíproco, subestimando que, consoante esta concepção, as forças produtivas não têm uma importância exclusiva para a explicação histórica, não são o único motor da história, fora das relações de produção, por isso mesmo que, segundo o ditame bem conhecido, os homens são os «actores e autores do seu próprio drama» histórico, a crítica de Sérgio desfigura a exacta fisionomia própria da doutrina e revela-se, em fim de contas, improcedente.

(T5) Por aquilo que concerne à ciência como força produtiva, ver: Gerhard Kosel, Produktivkraft Wissenschaft, Berlin, 1957; S. G. Stroumiline, «Le Rôle de la science dans le développement des forces productives, Recherches Internationales, n. ${ }^{\circ}$, Paris, 1961, pp. 41-73; A. A. Zvorykine, «Science et production», Etudes économiques, n. ${ }^{\circ}$ 140, Paris, 1962, pp. 1-13; "La Science, force productive directe», Impact, vol. XIII, n. ${ }^{1}$, Paris, 1963, pp. 49-61.

(76) Sobre a elaboração histórica da categoria de forças produtivas, ver: Arkadi A. Uibo, «A Elaboração dos problemas do materialismo Histórico por Marx e Engels, em "A Ideologia Alemãu,, Raízes Teóricas da Formação Doutrinal de Marx e Engels (1842-1846), Prefácio, selecção e organização de $V$. de Magalhães-Vilhena, colecção «Dialéctica» por nós dirigida, voi. 5, Livros Horizonte, Lisboa, 1981, pp. 117-154.

Berlin, 1965.

( $\left.{ }^{\mathrm{TT}}\right)$ Marx, Theorien über den Mehrwert, $M E W, \mathrm{Bd} .26,1$, 
Por outra banda, a categoria anti-científica, irracionalista, de «fatalidade», ao arrepio do que Antonio Sérgio afirma repetidas vezes $\left({ }^{78}\right)$, é de todo estranha à doutrinação do materialismo histórico tal como a expõem os textos de base. Ao invés, topa-se a cada página dos vários escritos de um Antero de Quental, escritos onde jamais se vislumbra uma só noção propriamente marxista.

Bakuninista, e nunca pensador marxista $\left({ }^{79}\right)$, Antero de Quental (e igualmente Oliveira Martins) repetiu entre nós a tão descabida ideia da fatalidade da evolução socioeconómica. Afigura-se-nos por isso mesmo muito estranho que António Sérgio, em vez de criticar com a severidade que merece essa ideia de Antero, retomada de Bakúnine, do fatalismo social, e designadamente do fatalismo económico (cúmulo do despropósito no «filósofo da liberdade» que ambicionava ser Antero), António Sérgio, ao revés, busque apoio em Antero para se opôr a uma concepção da história e da acção política que é precisamente antagónica de toda passividade fatalista, inquestionavelmente irredutível a todo fatalismo político e histórico.

Ora, a afirmação de Sérgio é tanto mais estranha quanto é certo que a difusão da concepção materialista da história, nos países latinos, se fez, nos fins do século XIX e começos do século XX, sobretudo através de dois livros de António Labriola, intitulados em italiano e em francês respectivamente: Saggi intorno alla concezione materialistica della storia:

I, Roma, $1895\left(1895^{2} ; 1902^{3} ; 1934^{4} ; 1938^{5} ; 1939^{6} ; 1945^{7} ; 1953^{8}\right)$;

II, Roma, $1896\left(1902^{2} ; 1938^{2} ; 1939^{3}\right)$, e Discorrendo di socia- * 83

83, 84-85, 91 .

(7S) Entre outros passos: Ensaios, VII, Lisboa, 1954, pp. 77, 82,

$O$ Ao que sabemos, a ideia de um Antero pensador marxista - contrapartida da posição de Sérgio - acha-se explanada principalmente no livro do professor brasileiro Luis Washington Vita: Antero de Quental, Rio de Janeiro, 1961. Impossibilitados de o consultar, não podemos discutir agora os seus argumentos. Mas de qualquer forma, a sua tese é inaceitável. Como cremos mostrar suficientemente neste trabalho, a incompatibilidade é total entre a actuação e os escritos de Antero por um lado, e a actuação e os escritos de Marx e Engels, por outro. Se Antero não foi propriamente anti-marxista, deve-se isso tão-só ao seu completo desconhecimento do marxismo. Não há de resto em todas as prosas e cartas de Antero a mais leve referência precisa à doutrina marxista. Mas é mais do que evidente que toda a orientação do seu espírito vai em sentido oposto ao marxismo. Ademais, a afirmação do contrário implicaria provar que Antero não foi bakuninista nem proudhoniano. Ora que ele foi uma e outra coisa, e que o não ter sido ele marxista é a razão primordial da alta significação doutrinal que ele tem revestido para Sérgio (e para outros mais através dele), cremos resultar claramente deste nosso livro. 


\section{Idealismo Histórico-Social}

lisnio e di filosofia, Roma, 1898 (19022; 19393; 19394; 19535), e Essais sur la conception máterialiste de l'histoire, trad., Paris, 1897 (19022; 19283) e Socialisme et Philosophie (Lettres à G. Sorel), Paris, 1899.

Ora Labriola que designava a filosofia marxengelsiana pela expressão filosofia della praxis, considerando-a (ao contrário dos revisionistas) como auto suficiente e independente de qualquer outra corrente filosófica, estimava precisamente que a «filosofia delia praxis» constituía «il midollo del materialismo storico» $\left({ }^{80}\right)$. O que queria dizer que o materialismo histórico «parte dalla praxis, dallo sviluppo della operosità, e como è la teoria dell'uomo che lavora, cosi considera la scienza stessa come um lavoro» $\left(^{81}\right)$.

Ademais, sabido como é que a apresentação da concepção materialista da história por Antonio Labriola, - destacado professor universitàrio italiano e mestre do filòsofo idealista Benedetto Croce - era altamente estimado pelas personalidades socialistas mais representativas da época, a saber: Engels, Kautsky, Plekhánov, Mehring, Lafargue, Lénine, não se vê bem, quer-nos parecer, a razão por que autores de amplíssima e sólida cultura e de indubitável probidade, como Sérgio, e, para mais, como ele, de inspiração socialista, e que não podiam desconhecer a obra reputada de um Labriola, ao tomarem posição contra a teoria materialista da história e ao discutirem algumas das suas principais ideias procediam como se não quisessem distinguir o seu rigoroso conteúdo das suas mais transviadas deturpações.

Da mesma maneira, Sérgio na sua crítica, não tem qualquer referência a outro ponto fundamental da concepção; a saber, a lei da correspondência entre as relações de produção (e as relações de produção são, em primeiro lugar, as relações dos homens com os meios de produção) e o nível e o carácter das forças produtivas, É esta lei uma das mais gerais e das principais do processo histórico, segundo o materialismo histórico, por isso mesmo que revela as forças motrizes mais profundas do desenvolvimento social, que estabelece precisamente $o$ papel determinante das forças produtivas face às relações de produção, isto é às relações sociais fundamentais. $\mathrm{O}$ nível das forças produtivas condiciona os rasgos essenciais das relações de produção cujo conjunto

(80) Antonio Labriola, Discorrendo di socialismo e di filosofia, in Saggi sur materialismo storico a cura di V. Gerratana e A. Guerra, Roma, 1964, p. 207.

(\$1) Ob. cit., 1964, p. 223. 
constitui a estrutura económica da sociedade. Sempre consoante esta concepção, é essa estrutura que constitui a base em que assentam a superestrutura política e jurídica de uma dada formação social, e as formas de consciência social que lhe correspondem. Se bem a entendemos, a crítica de Sérgio não nos parece divisar o laço interno orgânico que nesta concepção liga todos os aspectos da vida social à produção social. Assim, a ciência é força produtiva (e mesmo em dada conjuntura força produtiva directa) e forma da consciência social: por esta, passa-se à superestrutura e por aquela, à sua base. Acresce que a isto se prende a tese de Marx de que, em circunstâncias dadas, a teoria se converte em força material $\left({ }^{82}\right)$.

Da mesma forma, os reparos de Sérgio não têm em consideração toda a extrema complexidade que na dialéctica materialista da sociedade assume a categoria de «ser social» e designadamente o problema das suas relações com a categoria de «matéria» que exprime a essência da concepção materialista do mundo, e com a categoria de «consciência social». Ao criticar a noção de «matéria» e recusando a descriminação entre os dois tipos fundamentais de materialismo, o metafísico e o dialéctico, Sérgio não só não reconhece que para este (ao contrário daquele) a categoria de matéria não é exclusivamente uma categoria do ser físico, mas que o que há de qualitativamente novo na concepção dialéctica materialista de matéria é a inclusão da base material da sociedade na categoria filosófica de matéria, e que esta é, por consequência, uma categoria basilar do materialismo histórico, a matéria sendo assim objecto de estudo das ciências sociais.

A categoria filosófica de matéria reflecte tanto os fenómenos da natureza como os fenómenos materiais da sociedade, reflecte a propriedade universal dos objectos e processos da natureza e da sociedade: a propriedade de ser uma realidade objectiva, quer dizer: de ter uma existência independente da consciência que a reflecte.

É evidentissimo que dizendo isto não queremos inculcar um instante sequer que são estas noções que devam ser aceitas dogmaticamente sem discussão ou mesmo que toda investigação nestes domínios esteja terminada e não haja ainda e sempre problemas em aberto. Queremos apenas significar que

(82) Sobre este ponto, permitimo-nos remeter para o nosso estudo "Ideia e Matéria. A Teoria, Força Material», Antigos e Modernos. Estudos de Historio Social das Ideias, Livros Horizonte, Lisboa, 1983. Uma edição abreviada de este texto com o título «A Teoria, Força Material», Ideia e Matéria. Comunicações ao Congresso de Hegel 1976, Livros Horizonte, Lisboa, 1976, pp. 9-50. 


\section{Idealismo Histórico-Social}

uma crítica fundamentada da dialéctica materialista da história não pode descurar a análise destes pontos $\mathrm{e}$ de outros ainda com perfeito conhecimento das pesquisas efectuadas pelos especialistas mais qualificados, sem limitações das línguas em que esses trabalhos por ventura se achem escritos. Tivesse Sérgio discutido seriamente, em profundidade, as noções fundamentais que são efectivamente as do materialismo histórico, analisado criticamente a sua verdadeira problemática, combatido impiedosamente as estruturas dogmáticas dos seus adeptos sectários que desvirtuavam a doutrina, e teria sem dúvida (assim o pensamos) prestado como ninguém melhor do que ele entre nós o poderia ter feito, um inapreciável serviço ao desenvolvimento da historiografia portuguesa, só comparável, talvez, ao que representavam para esse desenvolvimento as suas próprias indagações históricas. Mas, lamentavelmente, ao que estamos em crer, não foi o que sucedeu. Sérgio não criticou de facto a doutrina que ele, no entanto, afirmava conhecer, e que, na verdade, está em muitos pontos bem mais próxima do seu próprio pensar do que ele entrevia, e em todo o caso infinitamente mais próxima do seu pensar que das concepções que ele atribui à doutrina e que, como tal, ele combate. E combate vitoriosamente, é bem de ver. Se a doutrina do materialismo histórico fosse realmente o que Sérgio sempre disse que ela é, não faltariam motivos para a desmantelar, e a razão estaria do lado de Sérgio. Mas não está; e não está porque esse não é conteúdo da doutrina. A refutação do seu sucedâneo, criado pelo próprio autor da polémica, afigura-se-nos finalmente sem alcance, e mesmo estéril. Por uma vez, foi acaso uma polémica vã. Quando menos, assim o supomos.

António Sérgio afirma peremptoriamente conhecer a doutrina («.... acreditem que não faço confusão alguma, e que conheço a doutrina» ( $\left.{ }^{83}\right)$ ), e sabemos ser esse o seu firme convencimento. Os factos, porém, provam insofismavelmente o contrário, temos, com tristeza, que reconhecê-lo. Mas em boa verdade deve-se reconhecer também que o surpreendente seria que assim não fosse. Que isto pudesse ocorrer e ocorresse com um intelectual do seu quilate entre nós (como por então ocorria igualmente além fronteiras $\left.{ }^{(84)}\right)$, não é decerto sem

1949, p. 61.

(") Prefácio da segunda edição do t. I dos Ensaios, Coimbra,

(“) Veja-se a pertinente análise, excelentemente documentada, do Professor Pierre Vilar: «Marxisme et histoire dans le développement des sciences humaines. Pour un débat méthodologique», Studi Storici, I, n. ${ }^{\circ}$, Roma, 1960, pp. 1008-1043, para o conhecimento do contexto ideològico europeu respeitante à questão em apreço. 
significação. De resto, tudo faz pensar que não é fortuita a coincidência em muitos pontos característicos das posições assumidas por Sérgio e por autores estrangeiros representativos, sendo certo que, por uma grandíssima parte, o característico nessa coincidência de atitudes não é, por via de regra, fruto de qualquer influição directa exercendo-se de um autor sobre outro. A razão da coincidência é mais funda: as suas raízes são sociais. Mas no caso que estudamos, a obra sergiana, neste ponto, ressente-se fundamente das inóspitas condições ambientais em que surgiu e se desenvolveu - aquelas «condições» reinantes de que, como sabemos, não se the afigura racional nem justo não se curar sempre ${ }^{85}$ ) - e a que ele mesmo lucidamente se referia com justificado amargor ao notar que gostaria de ter levado, sem dúvida, uma vida menos absorvente, menos desvairada, menos incerta, menos desfavorável ao estudo do que foi a sua: a de professor, por exemplo. Bem orientado, desde princípio e num país onde encontrasse mestres (acrescenta ele) daria, com certeza, muito mais do que dei ${ }^{(86)}$. Mestres ao seu nível, e uma crítica proba, culta, inteligente, não a trapaça ignara, o charlatanismo audaz, a copiosa constelação de «facadas» (como ele próprio disse) que frequentissimamente the atiraram (por todos os rumos «no 'Bairro Alto' lúgubre que é a vida político-intelectual portuguesa, em não pequena parte» $\left({ }^{87}\right)$ ), os plumitivos intelectuais, os «supersérgicos» de toda a sorte.

Mas não só isto. António Sérgio não contestou apenas o que na filosofia de Marx e Engels - o materialismo dialéctico - se designa por concepção materialista da história. Para Sérgio (como para o reformista socialista Bernstein, como para o idealista italiano Benedetto Croce (88 )) não há materialismo na doutrina de Marx. A começar, naturalmente, pelo materialismo histórico, teoria a que, na opinião dos críticos, entre os quais se conta Sérgio, de modo algum quadra a designação de «materialismo». Padece esta crítica, cremos nós, de interpretações erróneas.

Vamos, pois, tentar explicar-nos.

Consoante os seus criadores, o materialismo histórico $\left({ }^{89}\right)$

(85) Ensaios, I², Coimbra, 1949, pp. 456-459.

(M) «Uma Entrevista com António Sérgio», O Diabo, VI, n. ${ }^{\circ} 279$, Lisboa, 1940, p. 3, col. 4 e p. 7 , col. 1.

(1) Ensaios, I², Coimbra, 1949, p. 447; cf. pp. 447-449.

(") Cf. Benedetto Croce, Matérialisme historique et économie marxiste. Essais critiques, trad., Paris, 1901, pp. 11-12.

$\left.{ }^{89}\right)$ A designação "historische Materialismus» topa-se, por exemplo, na Carta de Engels a Conrad Schmidt, de 5 de Agosto de 1890, in Marx-Engels, Ausgewählte Briefe, Dietz, Berlin, 1953, p. 501. 


\section{Idealismo Histórico-Social}

é um materialismo porque, precisamente, entre outras particularidades, recusa-se a considerar, como geralmente consideram os idealistas, que a sociedade seja um conjunto de acções mútuas psíquicas. (A expressão é do revisionista neokantiano e teórico reformista da social-democracia, Max Adler).

O porquê do «materialismo» nas designações «materialismo histórico» e «concepção materialista da história» foi claramente indicado por Cesare Luporini do seguinte modo: «i «rapporti di produzione» fra gli uomini vengono anche detti rapporti materiali (onde «materialismo storico») e ciò in un duplice senso: 1 ) perché all'interno di essi si realizza il rapporto materiali (ossia pratico-sensibile) dell'uomo con la natura fisica nella produzione economica; e quindi dall'intemo di essi si sviluppano le forze produttive «materiali» della società, su cui i rapporti di produzione sono fondati. Potremmo chiamare questo un uso ontologico del termine «materiale».

2) Perché questi rapporti di produzione esistono (nello spazio geografico e nel tempo storico) anche se non sono consaputi. Ed è questo un uso evidentemente gnoseologico del medesimo termine «materiale». Ma questi stessi «rapporti di produzione», benché realissimi, non sono poi, come tali, nulla di immediatamente sensibile, o fisico-sensibile, e sotto questo aspetto li potremmo anche dire obiettivamente «ideali» (purché a tale termine si tolga ogni sfumatura di trascendeza, rispetto al concreto dell'esperienza)» $(0 \mathrm{O})$.

Por via de regra, os adversários do materialismo histórico que contestam o seu carácter materialista, avançam os dois seguintes argumentos. No manual popular de sociologia, de Bukhárine, a que geralmente se reportavam, nos anos 20 e 30 , os que se interessavam pela concepção materialista da história, as duas principais objecções ao carácter materialista da concepção eram assim resumidas. Primeira: « .... Ils [os contraditores idealistas] «ramènent» le processus historique aux «besoins» ou aux «intérêts» matériels et triomphent ensuite facilement du matérialisme historique, en prouvant avec justesse que l'«intérêt» n'est nullement quelque chose de matériel, au sens philosophique du mot, mais apparemment quelque chose de psychique. Et, en effet, l'intérêt n'est nullement

$=M E W$, Bd. 37, Dietz, Berlin, 1967, p. 437. E nessa carta Engels condena justamente o mau emprego que por esse então se fazia na Alemanha tanto da palavra "materialistisch" como da própria expressão "historische Materialismus», havendo o mau hábito de tudo transformar «em simples frases».

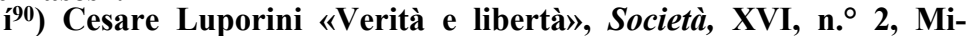
lano, 1960, p. 214. 


\section{Antonio Sérgio}

de la matière» (91). O segundo argumento é apresentado por Bukhárine através da seguinte citação de Max Zetterbaum: «Mais le rapport [entre os homens na sociedade] n'est nullement une chose matérielle dans le sens philosophique du matérialisme .... En général il est difficile de mettre «la structure économique», «base matérielle» du matérialisme historique, en rapport quelconque avec la «matière» du matérialisme philosophique, quel que soit le sens que nous lui donnons.... Et ceci concerne non seulement ce qui exerce l'action, mais aussi ce qui est créé par cette action. Les moyens de production .... sont plutôt des produits de l'esprit humain» $\left({ }^{92}\right)$.

Antonio Sérgio não parece pensar de outra maneira a este respeito.

Ora o que visa o materialismo histórico é precisamente a pôr a nu que a vida social em todas as suas manifestações não é uma vida psíquica consciente, que a sociabilidade não é inseparável da consciência, que o ser social e a consciência social, no sentido exacto de ambos os termos, sejam idênticos, que é fundamente erróneo pensar que sem consciência não há relações sociais. Resulta daí, em consequência, que por isso mesmo que todo processo da produção (ao contrário do que inculcam os idealistas históricos), não é sempre um fenómeno de consciência, o processo de produção é dito um processo material. Dizem-se materiais as relações sociais que se estabelecem objectivamente (no sentido materialista, e não idealista do termo), o mesmo é dizer, independentemente da consciência que os homens envolvidos nessas relações e que constituem essas relações, tenham ou possam acaso vir a ter, da estrutura dessas relações e da consciência que as modificações que introduzem nessas relações modificam o ser social. Do facto de que se vive, de que se tem uma actividade económica, de que se fabricam e trocam produtos (disse-se já) forma-se uma cadeia de sucessos objectivamente necessária, uma cadeia de desenvolvimento, de processos, independente da consciência social, que jamais a abarca na sua totalidade. É que o ser social é independente da consciência social dos homens. É esse o sentido da designação «material» na teoria materialista dialéctica da história. E porque considera o processo material de produção como a base das relações sociais e portanto a base da explicação do processo his-

(01) Cf. N. Boukharine, Théorie du matérialisme historique, trad., Paris, 1927, p. 153.

(92) Max Zetterbaum, citado por Bukhárine, ob. cit., pp. 153-154. 


\section{Idealismo Histórico-Social}

tórico que esta teoria é, no rigor do termo, materialista. Do que dizemos resulta claramente, como é fácil advertir, que o reparo feito a este respeito por Benedetto Croce e repetidas vezes evocado (inclusive por Sérgio) de que «questa denominazione di materialismo, .... non ha ragione d'essere nel caso presente, e ... fa nascere tanti malintesi» $\left({ }^{93}\right)$, està fora da questão.

Que a concepção materialista da história é materialista, e porque o é, ressalta ainda sem a sombra de uma dúvida deste simples enunciado: "Que a consciência em geral reflecte o ser, é uma tese geral de todo materialismo. É pois impossível não ver a sua conexão directa e indissolúvel com a tese do materialismo histórico que diz: a consciência social reflecte o ser social» $\left({ }^{04}\right)$. Por outras palavras: «O materialismo em geral reconhece a existência real e objectiva do ser (a matéria), independente da consciência, das sensações, da experiência, etc., da humanidade. $\mathrm{O}$ materialismo histórico reconhece o ser social independente da consciência social da humanidade» $\left({ }^{95}\right)$. Num caso como no outro, a consciência reflecte o ser. Trata-se de um processo único (com diferentes níveis) e una é a teoria que, reflectindo-o, o torna inteligível.

Acresce, porém, que repetidas vezes António Sérgio — e este é um rasgo primordial do seu idealismo crítico, e, designadamente do seu idealismo histórico-social, - não só recusou peremptoriamente $\mathrm{o}$ carácter «materialista» à teoria do materialismo histórico, mas a todo o conjunto da doutrina de Marx $\left({ }^{96}\right)$ : «pretensamente materialista», chegou mesmo a dizer $\left.{ }^{9 \mathrm{~T}}\right)$. Mas mais ainda: Sérgio contestou não só o próprio título de materialista que considera «improprissimo» para designar a doutrina dialéctica materialista $\left({ }^{98}\right)$, mas também a legitimidade e até a possibilidade de uma dialéctica mate-

(") Benedetto Croce, Materialismo storico ed economia marxista, Bari, pp. 34 e ss.

(“) V. Lenin, Materialismo y empiriocriticismo (Obras completas, t. 14), trad., ed. Cartago, Buenos Äires, 1960, p. 320.

(") Ob. cit., p. 322.

(") Ver, por exemplo: Um Problema Anteriano, Lisboa, s.d. [1943], p. 17; Notas de Esclarecimento, ed. Maranus, Porto, 1950. p. 22; Cartas de Problemàtica, Carta n. ${ }^{\circ} 10$, ed. Inquérito, Lisboa, 1954, pp. 2-3; Ensaios, VII, Europa-América, Lisboa, 1954, pp. 85-86, 92-93.

(") Cartas de Problemática, Carta n. ${ }^{\circ} 10$, Lisboa, 1954, p. 3. Ver ainda, entre outros textos: "Tese e Antítese nos Sonetos de Antero», Revista de Portugal, ${ }^{\circ}$ 1, Coimbra, 1937, p. 32.

(M) Notas de Esclarecimento, Porto, 1950. p. 22. Nos passos que citamos em todo este lance o texto de esta edição de 1950 (pp. 22 e 60) é fielmente reproduzido nos Ensaios, II*. Europa-América, 1957, pp. 263-264 e 339-340, com uma única excepção. 
rialista. «Rigorosamente [ao que disse], uma doutrina dialéctica não pode ser materialista» ("). E depois de acrescentar: «A ontologia materialista de que os nossos materialistas se nutrem é para mim tão fantástica como qualquer das outras» $\left({ }^{10 \circ}\right)$, escreve em Nota no fim do volume: «Nenhuma autoridade me nomeou professor (nem eu me nomeio) de materialismo dialéctico up to date dos «materialistas dialécticos» do meu país. Limitar-me-ei, por isso, a notar aqui:

1. ¿, que a expressão «materialismo dialéctico» contém duas faces que entre si discrepam, e que à medida que se ilumina a face do dialéctico vai caindo na sombra, a do materialismo;

2. ${ }^{\circ}$, que, conforme disse Ulianov, «dans leur oeuvre sur le matérialisme dialectique ils (Marx e Engels) soulignent plus le dialectique que le matérialisme» (Matérialisme et Empiriocriticisme, E.S.I., p. 284 [288]; 3. ${ }^{\circ}$, que um texto existe em que Carlos Marx, tendo escrito primeiro materialismo, substituiu tal palavra por naturalismo; e que, $4 .^{\circ}$, no célebre «manuscrito de 1844» escreveu ele o seguinte: «Nous voyons ici que le naturalisme ou l'humanisme réalisé diffère de l'idéalisme aussi bien que du matérialisme, et est en même temps la vérité qui les unit tous deux. Nous voyons en même temps que le naturalisme est seul capable de comprendre l'histoire universelle» (Oeuvres philosophiques, ed. Costes, tomo VI, p. 76). Mais tarde, a palavra naturalismo foi substituída por materialismo dialéctico; e infelizmente, quanto a mim: porque me parece que seria mais pròprio (se bem que menos estratégico, por assim dizer) adoptar aquele humanismo realizado do manuscrito de 1844, expressão com que plenamente estou de acordo» (101).

A citação é longa, mas parece-nos necessária, pois, sendo extremamente densa não quisemos desarticular a argumentação. Há no entanto vários pontos que merecem reparos. Assim:

1) Ao escrever neste seu requisitório: «a expressão «materialismo dialéctico» contém duas faces que entre si discrenam, e que à medida que se iluma a face do dialéctico vai caindo na sombra, logicamente, a do materialismo», fazendo seguir imediatamente esta frase destoutra, com uma citação de Ulianov, isto é de Lénine (10z): «que, conforme disse Ulia-

(") Ob. cit., p. 22. A única excepção a que nos referimos na nota precedente ocorre precisamente aqui. Nos Ensaios, II*, 1957, p. 264, a frase que citamos no texto esta assim reforçada: «Rigorosamente, uma doutrina dialéctica não pode ser materialista».

$(10 \circ)$ Ob. cit., p. 22.

(101) Ob. cit., p. 69.

(*6) Processo usual ao tempo para evitar a censura fascista. 


\section{Idealismo Histórico-Social}

nov, «dans leur oeuvre sur le matérialisme dialectique ils (Marx e Engels) soulignent plus la dialectique que le matérialisme» ", Sérgio inculca no espírito do leitor a ideia de que a sua afirmação tem por base uma asserção de V. I. Lénine. Ora, a verdade é bem diversa. A citação está feita de maneira inexacta e incompleta, o que tem por consequência supôr o leitor não só que a afirmação de Sérgio decorre de um texto de Lénine como ainda que o autor citado disse algo diverso do que ele na verdade quisera dizer. Com efeito, o que na tradução francesa do texto de Lénine está escrito é isto, que trasladamos da edição de que se serve Sérgio (embora não a consideremos rigorosamente exacta, e intercalando entre parênteses rectos, nos passos mais significativos, o texto original, a nosso ver muito mais explícito ainda do que a tradução para o ponto que interessa ao caso. Eis aqui a cita em questão:

«Issus de Feuerbach et mûris dans la lutte contre les rapetasseurs [trata-se de Büchner, Vogt, Moleschott, Dühring $V$. de M.-V.], Marx et Engels portèrent naturellement leur attention principale sur le parachèvement de la philosophie matérialiste, c'est-à-dire sur la conception matérialiste de l'histoire, et non sur la gnoséologie matérialiste. Par suite [Ot étovo], dans leurs oeuvres sur le matérialisme dialectique, ils soulignèrent plus la dialectique que le matérialisme [dialektitcheskii materializm, tchem dialektitcheskii materializm], et, traitant du matérialisme historique, ils insistèrent plus sur le côté historique que sur le côté matérialiste [na istoritcheskom materializme, tchem na istoritcheskom materializme]....

Nos adeptes de Mach n'ont pas compris le marxisme, pour l'avoir abordé en quelque sorte à revers. Ils se sont assimilé .... la théorie économique et historique de Marx, sans en avoir compris les fondements, le matérialisme philosophique [ne vyiasniv eë osnóvy, t. e. filosôfskogo materializma] » $\left({ }^{103}\right)$.

Isto é o que aí se lê. Citado integralmente, e com mais razão ainda situado no seu contexto, o trecho citado, como se vê, em nenhum caso pode servir para abonar a proposição de Sérgio.

2) Ademais de isso, a ideia aí exposta por V. I. Lénine tem manifestamente em vista um texto inequívoco do pró-

(103) Os sublinhados são do autor citado: V. I. Lénine, Euvres complètes, tomo XIII, Matérialisme et Empiriocriticisme, trad., Editions Sociales Internationales, Paris, 1928, p. 288. (Há traduções francesas mais recentes, de 1948 e de 1962 , mas nenhuma de elas é satisfatória. São preferíveis as traduç̃̃es alemã e inglesa.) Sotchinéniia, izd. 4. ${ }^{\circ e}$, t. 14; Materializm i impiriokrititsízm, Moskvá, 1953, pp. 315-316. 


\section{Antonio Sérgio}

prio Engels. Referimo-nos, como é óbvio, à Carta a Joseph Bloch de 21/22 de Setembro de 1890 (104). Nessa sua carta, como todos sabem, Engels, depois de referir que, segundo a concepção materialista da história, o factor determinante na história é, em última instância (in letzter Instanz), a produção e a reprodução da vida real, assevera: «Nem Marx nem eu próprio nunca afirmámos mais do que isto. Se por conseguinte alguém torce um tal asserto para lhe fazer dizer que o factor económico é o único determinante, transforma-o numa frase sem sentido, abstracta, absurda». E mais adiante acrescenta: «Marx e eu próprio somos em parte responsáveis pelo facto de que, por vezes, os jovens acentuem mais do que é devido o lado económico. O facto é que, para fazer frente aos nossos adversários, tivemos que sublinhar o princípio essencial negado por eles, e nem sempre tivemos o tempo, nem o lugar, nem a oportunidade de dar o devido lugar aos outros factores que participam na interacção. Mas quando se tratava de apresentar um fragmento da história, isto é, de passar da teoria à prática, o caso era diferente $\mathrm{e}$ não havia erro possível».

Assim também pelo que respeita ao materialismo e à dialéctica houve momentos na actividade doutrinal de Marx, como de Engels, como de Lénine, em que, por circunstâncias várias, insistiam mais sobre um ou outro dos dois aspectos que, não obstante, formam no seu pensamento um só todo indissolúvel.

3) Pelo que respeita à segunda citação que aduz Sérgio na referida nota do seu opúsculo (105) - esta dos Manuscritos Económico-Filosóficos de 1844, de Marx, há que observar que se, com efeito, a expressão «humanismo realizado», com a qual Sérgio nos diz estar plenamente de acordo, se topa efectivamente, tanto na péssima tradução francesa utilizada por Sérgio (mas que era de resto a única existente ao tempo naquela língua e a única então conheci.da entre nós) como mesmo no texto original do jovem Marx, o seu sentido exacto não é correctamente interpretado por Sérgio na ocorrência. Na verdade, desgarrada do contexto ideológico em que se integra e das premissas aí sustentadas - a posição peculiar de Marx e de Engels face ao materialismo contemplativo ("anschauender Materialismus») de Feuerbach, essa expressão citada não

(,04) In Marx-Engels, Ausgewählte Briefe, Dietz, Berlin, 1953, pp. 502-504; MEW, Bd. 37. Dietz, Berlin, 1967, pp. 463-465: Selected Correspondence, Progress Publishers, Moscow, 1975, pp. 394-395. 1957 , pp. 339-340.

(105> Notas de Esclarecimento, Porto, 1950, p. 69; Ensaios, IP, 
permite compreender rigorosamente o pensamento marxengelsiano ainda em gestação (106), e de ai a sua ulterior substituição por outra que mais cabalmente conviesse à doutrina.

$\mathrm{Se}$ as referidas expressões, citadas por Sérgio, «naturalismo ou humanismo realizado» ou mesmo ainda «reale $\mathrm{Hu}$ manismus», são susceptíveis de lhe agradar, as exactas expressões de que se serve Marx e sobretudo o conteúdo que elas buscam exprimir nos Oekonomisch-philosophische Manuskripte, de 1844, rejeita-o Sérgio obviamente, a saber: a dialéctica da natureza, de autêntico cariz materialista, embora ainda não plenamente elaborada. São estas as expressões: «vollendeter Naturalismus = Humanismus, als vollendeter Humanismus = Naturalismus» e «durchgeführte Naturalismus oder Humanismus» $\left({ }^{107}\right)$. Ou, numa tradução conhecida: «naturalisme achevé = humanisme, en tant qu'humanisme achevé = naturalisme» e «naturalisme conséquent, ou humanisme» $\left({ }^{108}\right)$.

Estes passos de um escrito da juventude de Marx, não o esqueçamos, só integrados no seu verdadeiro contexto, e este no desenvolvimento da formação doutrinal de Marx situado nos quadros ideológicos e sociais do seu tempo, podem ser hoje cabalmente entendidos, como é do conhecimento dos especialistas da questão, e não já só de eles. Certo é que, no tempo em que Sérgio escreveu o passo que comentamos, por via de regra, pouco se sabia do assunto, fora de um círculo restrito de investigadores. Ademais, as próprias edições do referido texto de Marx, para já nada dizer das traduções usuais, eram defeituosíssimas $\left({ }^{109}\right)$.

(106) Ver: Raízes Teóricas da Formação Doutrinal de Marx e Engels (1842-1846), Prefácio, selecção e organização de Vasco de Magalhães-Vilhena, na colecção por nós dirigida "Dialéctica", vol. 5, Livros Horizonte, Lisboa, 1981.

(107) $M E W E B$ 1, Dietz, Berlin, 1968, pp. 536-577.

(10s) Manuscritos de 1844. Economie politique e philosophie, Ed. Sociales, Paris, 1962, pp. 87-136.

(109) Para informação do leitor, limitamo-nos a remeter para a melhor edição actual do texto: Karl Marx, "Oekonomisch-philosophische Manuscripte aus dem Jahre 1844», Marx-Engels, Werke. Ergänzungsband 1, Dietz, Berlin, 1968, pp. 465-588. Urna excelente versão inglesa: K. Marx, «Economic and Philosophie Manuscripts of 1844», in Marx-Engels, Collected Works, voi. 3, Progress Publishers, Moscow, 1975, pp. 229-346. Sobre a exacta significação filosófica e ideológica dos chamados «manuscritos de 44», bem diversa do que nas suas Notas de Esclarecimento, de 1950, parece supor Sérgio (que aliás não conhecia o texto correcto dos Manuscritos, - só publicados ulteriormente em edições e traduções rigorosas), basta referir, a título de exemplo, mormente a: L. N. Pajjitnov, $U$ istókov revoliutsiónnogo perevoróta v filosofa. «Ekonomítchesko-filosófskie rúkopissi 1844 goda» K. Marksa, (Nas Origens da transformação Revolucionária na Filo- 
Ocorre ainda, como se sabe, que as vozes naturalismo e humanismo serviam por essa ocasião ao filósofo materialista alemão Ludwig Feuerbach, - então particularmente estimado por Marx pela sua posição nas contendas ideológicas da época $(110)$ - para designar precisamente o materialismo. O princípio antropológico feuerbachiano, dirigido contra a religião e o idealismo, acentuava muito exactamente a necessidade, no tocante à análise dos problemas filosóficos, de considerar o homem como parte integrante da natureza, entendido materialisticamente. E assim o entendeu já o jovem Marx nos Manuscritos de 44.

Mas prossigamos. Não se detém aqui a crítica de Sérgio. Uma outra afirmação, mas relacionada com os reproches (o termo é de Sérgio) a que acabamos de nos reportar, é a de que, em seu entender, só o materialismo mecanista puro é que merece o nome de materialismo, só cabe o rótulo de materialismo genuíno à doutrina que considera o mental como um epifenomeno, sem poder activo nos aconteceres do existente, ou físico ou social. Demais disso, ao que diz, todo materialismo é por natureza mecanista, toda dialéctica necessariamente idealista. «A meu juízo existe um único materialismo autêntico: o mecanista .... A noção de dialéctico, no meu modo de ver, antolha-se incompatível com a de materialismo». E porquê? - pergunta. - «Porque a dialéctica, por um lado, sustenta uma evolução regulada por ideias (que se pauta pela transição de ideia a ideia) e apresenta como fundamental, por conseguinte, o quê? - Não a matéria, mas um jogo de ideias; e porque admite, outrossim, a reacção das ideias do ser humano dentro do evoluir da realidade social, - concepção in-

sofia. Os «Manuscritos Económico-Filosóficos de 1844»), Moskvá, 1960. Uma trad, do primeiro capítulo de esxe íivro, pp. 5-30, e de um outro estudo do mesmo investigador acham-se reunidos sob o título: «Les Manuscrits économico-philosophiques de 1844», Recherches internationales, IVe année, n. ${ }^{\circ} 11$, Pans, I960, pp. 80-117. Mas há também motivos para citar: Economie and Philosophie Manuscripts of 1844, by Karl Marx, Edited with an Introduction by Dirk J. Struik, International Publishers, New York, 1964 (197710); e T. I. Oizerman, Formirovénie filosofa marksísma ${ }^{2}$, Moskvá, 1974; trad.: The Making of Marxist Philosophy, Progress Publishers, Moscow, 1981. Sobre o problema da unidade do materialismo e do humanismo nesses manuscritos económico-filosóficos e sobre o seu significado doutrinal, veja-se: Auguste Cornu, Karl Marx e Friedrich Engels, vol. Ili, PUF, Paris, 1962, pp. 87-177, e W. Schuffenhauer, Feuerbach und der iunge Marx. Zur Entstehungsgeschichte der marxistischen Weltanschaunng ${ }^{2}$, Berlin, 1972.

(110) Ver a reveladora carta, até há pouco inédita, que Marx endereçou de Paris a Feuerbach, em 11 de Agosto de esse mesmo ano de 1844, in MEW, Bd. 27, Dietz, Berlin, 1963, pp. 425-428. 


\section{Idealismo Histórico-Social}

compatível com o epifenomenismo, que é noção inerente a um materialismo exacto» $\mathrm{C}^{111}$ ).

Ao que Sérgio sentenceia, só quem siga a doutrina do epifenomenismo no absoluto rigor (quer dizer: quem tenha como indubitável que a consciência não passa de um fenómeno acessório, cuja presença - ou cuja ausência - não tem influxo de qualquer espécie no fenómeno principal que se considera) pode chamar-se com direito «materialista», e não é de facto materialista quem quer que admita a acção recíproca da consciência humana e do mundo físico. Só a tese do epifenomenismo estimando que a consciência é tão incanaz de qualquer reacção sobre o organismo físico correspondente como a nossa sombra sobre os nossos passos, quando caminhamos, e que assim a história inteira da humanidade, se não houvesse de facto consciência no homem, teria sido aquilo que realmente foi, realiza uma concepção de verdadeiro materialismo $\left({ }^{112}\right)$.

Mas venhamos ao que António Sérgio parece considerar o essencial da sua argumentação. Que diz ele? Interessa transcrever na íntegra as suas mesmas frases:

«Com efeito, só é materialista verdadeiro [segundo Sérgio] quem veja na consciência um epifenómeno (e por isso incapaz de reagir sobre as acções da natureza), e nas ideias, «reflexos das coisas no nosso cérebro» (o que é desconhecer por completo o verdadeiro carácter das ideas). Por outras palavras: quem suponha que as ideas são «reflexos das coisas no nosso cérebro» não pode admitir ao mesmo tempo que as ideas reajam sobre as coisas, não pode conceber uma acção recíproca entre a consciência e o ambiente físico, entre o ser inteligente e o corpo social. Aceitar essa acção recíproca - como faz o chamado «materialismo dialéctico»-é reconhecer a eficácia das ideas, e reconhecer a eficácia das ideas é afirmar que elas não são reflexos, e negar a doutrina do materialismo. De nada serviria distinguir aqui entre o materialismo «dialéctico» e o «mecanista»: só o materialismo mecanista é verdadeiramente materialista, e a noção de dialéctica é in-

(m) Para uma pertinente crítica dialéctica materialista da teoria psicológica mecanicista do epifenomenismo (e, por conseguinte, uma prova mais do infundado da posição de Sérgio a este respeito), ver designadamente: A. N. Leóntiev, Problémy razvítiia psíkhiki, Moskvá, 1965, sobretudo pp. 17-18, 23-27, 76, 170-171, 251-252, 327, ( 1972 $^{3}$ ) ; Le Développement du psychisme, trad., Ed. Sociales, Paris, 1976.

(Mî) «Tese e antítese nos Sonetos de Antero», Revista de Portugal, n..$^{\circ}$, Coimbra, 1937, p. 25. 
compatível com a de materialismo. O «materialismo dialéctico», com efeito, não afirma que a dialéctica é material, mas que a materialidade é dialéctica: ora, dizer que o desenvolvimento da realidade se leva a efeito dialécticamente é dizer que a marcha da realidade se pauta pela marcha das ideas, que a cadeia dos fenómenos reproduz a cadeia dos pensamentos, - e sustentar, por consequência, uma doutrina idealista. Todo dialecta há-de pensar com Antere que 'o universo, análogo no fundo ao espírito, só pelas suas ideas imanentes existe e se governa», e que «a evolução, vista desta altura, não é somente o processo mecânico e obscuro da realidade: é o próprio processo dialéctico do ser, tem as suas raízes, comuns com as raízes da razão, na inconsciente mas fundíssima aspiração da natureza a um fim soberano, a consciência de si mesma, a plenitude do ser e a ideal perfeição .... O $\mathrm{O}$ universo.... transfigura-se: o seu movimento aparece como uma sucessão e encadeamento de ideas'................ Ora, com isto coincide, a final de contas, o chamado «materialismo dialéctico», quando marca como termo da evolução humana o salto do reino da necessidade para o reino da liberdade. É que Antero sabia que era idealista; e os autores do «materialismo dialéctico», sendo-o também, tinham o ingénuo preconceito de o não serem» $\left({ }^{113}\right)$.

Aqui está (114). Não é por isso de estranhar que, noutro escrito, mas na mesma ordem de ideias, Sérgio conclua: «Quanto a mim, junto das doutrinas de inspiração socialista é a ideia do materialismo uma superfetação nociva» (115), como «superfetação inteiramente inútil, e ademais tautológica»

(113) Ob. cit., pp. 31-32.

$\left({ }^{n}\right)$ Ademais acrescente-se que a teoria dialéctica materialista do Reflexo - Wiederspiegeiungstheorie, Abbildtheorie, teóriia otrajéniia, nas expressões dos seus criadores, - cuida do reflexo da realidade objectiva - natureza e sociedade - na consciência dos homens - o que dista muito, para os que entendem os quadros teóricos da questão, do que a expressão infeliz de que frequentemente, se não sempre, usa Sérgio, parece querer inculcar, a saber: a ideia, simplista, perfeitamente inadequada $\mathrm{e}$ inexacta de que, para os materialistas dialécticos, «reflexo» significa tão-só «reflexo das coisas no cérebro dos homens». Voltaremos ao tema ao abordar mais de espaço a exacta e rigorosa concepção dialéctica materialista do reflexo. Aqui, cite-se apenas, numa língua acessível entre nós, uma excelente exposição global recente do assunto: Dieter Wittich / Klaus Gössler / Kurt Wagner, Marxistisch-Leninistische Erkenntnistheorie ${ }^{2}$, Deutscher Verlag der Wissenschaften, Berlin, 1980.

(115) Cartas de Problemática, carta n. ${ }^{\circ}$ 10, Lisboa, 1954, pp. 2-3. Mas também: "Temas para Meditação», Seara Nova, XVII, n.॰ 537, Lisboa, 1937, pp. 196-197; Ensaios, P, Coimbra, 1949, pp. 58-63; Notas de Esclarecimento, Porto, 1950, p. 22; Ensaios, VII, Lisboa, 1954, p. 93; Vili, Lisboa, 1958, p. 212. 


\section{Idealismo Histórico-Social}

se lhe afigura outrossim o que qualifica de «artificioso esquema da «lògica» hegeliana» $\left({ }^{116}\right)$.

Em seu entender foi acidente deplorável da história que ao socialismo se tivesse unido, a certa altura, «uma metafísica com preconceitos materialistas e que se intitula materialista, sendo de facto idealista nas suas pressuposições fundamentais» $\left({ }^{117}\right)$.

Assim argumenta Sérgio, quanto ao essencial, pelo que aqui importa.

Ora, supomos nós que, na ocorrência, é bastante notar:

1) que o longo trecho que trasladámos há pouco contém, se não estamos em erro, a súmula mais completa e sistemática da argumentação de Sérgio sobre este tema;

2) que, na crítica de Sérgio, não vislumbramos ficasse demonstrado que na teoria do reflexo (correctamente entendida e não, claro, através das aberrantes distorções dos seus adeptos abusivos ou dos oponentes malévolos ou mal informados), não se pode conceber uma acção recíproca entre a consciência humana e o ambiente físico (e social), mas que foi tão-só avançada esta afirmação de que reconhecer a eficácia das ideias e afirmar que elas são reflexos, é negar a doutrina do materialismo; viç̧ão

3) que na crítica de Sérgio foi tão-só expressa a con-

a) que de nada serve distinguir aqui entre o materialismo dialéctico e o mecanista (quando muito ao contrário, como já comprovámos, esta distinção é capital, designadamente no que toca às respectivas teorias epistemológicas do reflexo, radicalmente distintas num e noutro materialismo; cumpre de facto distingui-los - e perfeitissimamente, se se quer entender alguma coisa do assunto em discussão;

b) que só o materialismo mecanista é verdadeiramente materialista, - mas não foi dada a prova de uma nem de outra afirmação;

4) que, se é certo o materialismo dialéctico afirmar que a realidade é dialéctica, que, se é certo que dizer que a marcha da realidade se pauta pela marcha das ideias, ou dizer que a cadeia dos fenómenos reproduz a cadeia dos pensamentos é sustentar uma doutrina idealista, não menos certo, todavia, nos parece que na crítica em referência foi tão-só in-

(IIS) Cartas de Problemática, Carta n. ${ }^{\circ}$, Lisboa, 1952, p. 5.

(IIT) Isto, escreve Sérgio de passo, numa nótula na Seara Nova, XVIII, n. ${ }^{\circ}$ 553, 1938, p. 156. 


\section{Antonio Sérgio}

culcado - mas de forma alguma administrada a prova - que dizer que o desenvolvimento da realidade se leva a efeito dialécticamente é dizer que a marcha da realidade se pauta pela marcha das ideias (assim como julga);

5) que na crítica de Sérgio a que nos reportamos foi afirmado, mas prescindindo de quaisquer provas, a) que todo dialecta há-de pensar, com Antero, que o universo é análogo no fundo ao espirito, e b) que ao invés de Antero que sabia ser idealista, os autores do materialismo dialéctico, sendo-o também, tinham o ingénuo preconceito de o não serem;

6) que não só é improcedente e carente de provas o argumento de Sérgio de que de nada serve distinguir o materialismo dialéctico do materialismo mecanista, mas ainda que Sérgio parece confundir, identificando-as - o que o pleno conhecimento da questão mostra à evidência ser despropositado e abusivo - as concepções do «reflexo» nas doutrinas epistemológicas de teor empirista conhecidas pelo nome de realismo (118) (e que um Windelband, por exemplo, como Sérgio aliás, argutamente criticaram) e as ideias basilares da teoria materialista dialéctica do reflexo, que num ou noutro ponto esquissámos nesse nosso livro, evidenciando, ao mesmo tempo os rasgos essenciais particulares de que se reveste na compreensão do facto histórico $\left({ }^{119}\right)$;

(118) Ver Adam Schaff, La teoría de la Verdad en el materialismo y en el idealismo, trad., Ed. Lautaro, Buenos Aires, 1964. Para novos desenvolvimentos, ver o importante e lúcido estudo de G. A. Kursánov, Léninskaia teóriia istínny $i$ krísis burjuáznikh vozzrénii (A Teoria Leninista da Verdade e a Crise da Consciência Burguesa), Moskvá, 1977, e Veritas. Fundamentos de la teoría leninista de la verdad y crítica de las concepciones idealistas modernas, ed. Progresso, Moscú, 1977.

$\left({ }^{1, \#)}\right.$ Acerca da teoria do reflexo em particular no respeitante às ciências sociais e designadamente à história, ver o terceiro volume da obra colectiva, em russo, publicada sob a direcção de Tódor Pavlóv, Léninskaia teóriia otrajéniia $i$ sovreménnaia naúka. III: Teóriia otraéniia $i$ obchtchevstvoznánie (A Teoria do Reflexo e as Ciências Contemporâneas. Ill: A Teoria do Reflexo e as Ciências Sociais), Sofia, 1973. Cf. também o volume, em russo, igualmente dirigido por Tódor Pavlóv, Léninskaia teóriia otrajéniia i sovreménnosti (A Teoria Leninista do Reflexo e a Actualidade), Sofia, 1969, esp. pp. 647-719. De entre os temas tratados nestas obras, sobre o ponto particular que aqui nos ocupa, permitimo-nos destacar a título de exemplo: a teoria do reflexo e o recente desenvolvimento das ciências sociais. A teoria do reflexo e alguns problemas da especificidade do conhecimento social: o carácter criador do reflexo de cognição social; a teoria do reflexo e a metodologia científica do conhecimento dos fenómenos sociais e os seus pressupostos socio-filosóficos; a questão da determinação da consciência social: raízes sociais e gnoseológicas da ideologia; análise da estrutura da consciência social, suas diferentes formas; 


\section{Idealismo Histórico-Social}

7)

que na referida argumentação crítica de Sérgio a que nos estamos reportando foi tão-só afirmada a coincidência- o «a final de contas» - do materialismo dialéctico com o passo de Antero transcrito aprovativamente por Sérgio; porém, a demonstração de essa coincidência, que a ser conseguida, não seria certamente desprovida de interesse, do ponto de vista de Sérgio, ficou igualmente por fazer. Ora, como foi Sérgio quem, citando Antero, falou de coincidência («....com isto coincide, a final de contas....»), não será certo que lhe caberia precisamente demonstrar a hipótese que aventava, explicando em que se relaciona (se é que se relaciona - o que não cremos) com o trecho de Antero, a celebérrima tese do salto do reino da necessidade para o reino da liberdade, e em que medida, e de que maneira, em seu juízo, esta tese, tida reconhecidamente como materialista no contexto engelsiano (bem diverso do da dialéctica idealista hegeliana da liberdade e da necessidade), enquadraria antes mais propriamente numa concepção idealista do que materialista da história, como Sérgio quis supor. De resto, que terá que ver com a dialéctica materialista, entendida no seu inteiro rigor, o ditame de Antero, citado por Sérgio, segundo o qual o movimento do universo «aparece como uma sucessão e encadeamento de ideias»? $\left({ }^{120}\right)$.

a ciência social como objecto de análise sociológica; a categoria de práxis social no processo do conhecimento; a teoria do reflexo de «antecipação», suas formas complexas e específicas; a teoria do reflexo e a natureza reflectiva da criação artística; natureza, estrutura e função reflectiva-cognitiva do conhecimento social; a categoria de «sujeito social».

$\left.{ }^{(12}{ }^{\circ}\right)$ Sobre a exacta significação - de primacial relevância para compreender a pleno a dialéctica materialista da história - da concepção relativa à «passagem do reino da necessidade ao reino da liberdade» como momento consecutivo ao da "passagem do reino da liberdade ao da necessidade» (o processo comporta dois momentos, e não um apenas) - de que fala Engels no Anti-Dühring (MEW, Bd. 20, Berlin, 1960, p. 264; trad, francesa, Paris, Ed. Sociales, 1950, pp. 322 e 324), - e sobre o seu enquadramento na história das ideias filosóficas e sociais, ver, por exemplo: Georges Plékanov, «Essai sur le développement de la conception moniste de l'histoire», Euvres Philosophiques choisies, vol. I, trad., Moscou, 1961, esp. pp. 504-610. Característico do idealismo de Antero de Quental, ao que a nós nos parece exacto, foi precisamente o não ter encontrado (como tão-pouco a encontrou o seu mestre Proudhon) a orientação filosófica que o levaria a compreender a dialéctica da liberdade e da necessidade, não tendo entrevisto, nem um nem outro, o que havia já de profundamente inovador na dialéctica idealista de Hegel, e mormente na lei dialéctica da negação da negação, para além do seu constructivismo especulativo. De passagem, digamos que a significação exacta desta lei dialéctica é coisa muito diversa do que àcerca dela escreveu Sérgio, como o leitor facilmente 
Como dissemos, o longo trecho que trasladámos há pouco contém, se não estamos em erro, a súmula mais completa e sistemática da argumentação de Sérgio sobre este tema. Mas tanto quanto podemos ajuizar, a demonstração cabal de este enunciar de teses não se vislumbra em nenhum dos escritos filosóficos de António Sérgio até agora publicados. E não sabemos que no seu espólio algum haja nesse sentido.

Paremos aqui de novo. Um ponto há ainda que demanda elucidação. O ponto é este:

Acontece, porém, que a leitura idealista - e precisamente porque idealista — da dialéctica materialista efectuada por Sérgio, não colhe. E não colhe porque a sua análise não vai ao âmago da questão $\left({ }^{121}\right)$.

A lógica dialéctica materialista, a lógica que toma o objecto no seu desenvolvimento, no seu movimento, nas suas transformações, e em que se exprimem as contradições objectivas, nada tem a ver com o que Sérgio por vezes escreveu a respeito de Hegel — páginas infelicíssimas que destoam na sua obra (122). A não rara incompreensão e o despropósito de Sérgio perante Hegel são significativamente comparáveis aos de um Brunschvicg e da grandíssima maioria dos universitários franceses (123) dos anos 20 e 30 de este século, exceptua-

se aperceberá reportando-se a qualquer das obras que citamos onde o assunto é devidamente tratado, e de que não temos aqui de nos ocupar. Permitimo-nos apenas remeter para Richard Kossolapov, Liberdade e Práxis Social. Bases gnoseológicas da concepção materialista da liberdade, no segundo volume da colectânea Práxis. A Categoria Materialista da Prática Social. Prefácio, selecção e organização de Vasco de Magalhães-Vilhena, na colecção por nós dirigida «Dialéctica», n. ${ }^{\circ} \mathbf{3}$, Livros Horizonte, Lisboa, 1980, pp. 87-110.

$(\mathrm{m})$ Sobre a possibilidade real, concreta da existência de uma dialéctica materialista e do seu verdadeiro conteúdo (de que não nos cabe aqui tratar), além de obras por nós mencionadas incidentemente noutra passagem de este trabalho, merecem destaque especial: $P$. $V$. Kópnine, Dialéktika kak Lógika i teóriia poznániia (A Dialéctica como Lógica e Teoria do Conhecimento), Moskvá, 1973 (trad.: Lógica dialéctica, Grijalbo Editor, México, 1966, - Dialectique logique et science, ed. du Progrès, Moscou, 1976) e E. V. Ilienkov, Dialektitcheskaia lógika (Lògica Dialéctica), Moskvá, 1974 (trad.: Dialectical Logic, Progress Publishers, Moscow, 1977). As traduções, porém, nem sempre exprimem plena e rigorosamente o denso e profundo pensamento dos autores. Uma menção muito especial deve ser feita ainda ao importantíssimo livro de Jindrich Zeleny, Die Wissenschaftslogik bei Marx und "Das Kapital», Akademie-Verlag, Berlin, 1968.

(12i> Por exemplo nos Ensaios, Vili, Guimarães Editora, Lisboa, 1958, pp. 214-218 e em variadíssimos lances das porém tão belas, tão ricas e sugestivas Cartas de Problemática, ed. Inquérito, Lisboa, 1952-1955.

(m) Cf. Henri Lefèbvre, «Lettre sur Hegel», La Nouvelle Critique, III, n. ${ }^{\circ 2}$, Paris, 1951, esp. pp. 99-101. 
dos um Lucien Herr, um Emile Meyerson, um Jean Wahl, um Alexandre Koyré.

Em completa oposição ao que sustenta o idealismo hegeliano, o curso objectivo do mundo (objectos e fenómenos da natureza e da sociedade) não é determinado pela lógica dos conceitos: na dialéctica da realidade objectiva radica a dialéctica dos conceitos, e não inversamente. A dialéctica subjectiva é reflexo da dialéctica objectiva. Não há pois identidade do lógico e do histórico (como não há identidade do ser e da consciência, do ser social e da consciência social). Ao contrário, é o curso lógico do pensamento que se acorda ao processo histórico objectivo do mundo e da sociedade para o reproduzir idealmente, por uma forma teoricamente generalizada, ainda que não coincida estritamente com ele. A sensibilidade, o conhecimento, o homem numa palavra, têm história, como têm história não só a sociedade mas também a natureza, e esse desenvolvimento histórico é dialéctico. Assim a justa teoria do conhecimento (que é ao mesmo tempo lógica e dialéctica) não pode ser outra coisa senão a expressão lógica do processo histórico do conhecimento no seu movimento progressivo $\left({ }^{124}\right)$.

(124) Sobre o desenvolvimento da dialéctica idealista na filosofia alemã clássica, sobre a elaboração da dialéctica materialista por Marx e Engels e sobre o processar do seu desenvolvimento na época leniniana, com particular realce para o contributo original de $V$. I. Lénine, as obras históricas de base, proporcionando uma visão global são: para os antecedentes imediatos do pensamento dialéctico do idealismo alemão clássico (nomeadamente em N. de Cusa, Bacon, Descartes. Pascal. Spinoza, Toland, Leibniz, Voltaire, Deschamps, Rousseau, Diderot), ver Geschichte der Dialektik. 14. bis 18. Jahrhundert. Leiter des Autorenkollektivs: Teodor Oiserman, Dietz Verlag, Berlin, 1979, e para temas mais pontuais dos referidos antecedentes imediatos, ver o denso e muito penetrante estudo de Hernâni A. Resende "Sur Tétude des prémisses théoriques de la pensée dialectique au sein des doctrines sociales en France au siècle des Lumières. Remarques de méthode», Annales Historiques de la Révolution Française, n. ${ }^{\circ}$ 4, Paris, 1983; para os demais temas mencionados no princípio da nota: Geschichte der Dialektik. Die klassische deutsche Philosophie. Leiter des Autorenkollektives: Teodor Oiserman, Dietz Verlag, Berlin, 1980 (nomeadamente: Kant, Fichte, Schelling e Hegel): Geschichte der marxistischen Dialektik. Von der Entstehung des Marxismus bis zur Leninschen Etappei*. Verantwortlicher Redakteur: M. M. Rosental, Dietz Verlag, Berlin 1975; Geschichte der marxistischen Dialektik. Die Leninsche Etappe. Verantwortlicher Redakteur: G. A. Kursanov, Dietz Verlag, Berlin 1976 (trad, do russo: Histoire de la dialectique marxiste, sous la direction de G. A. Kursanov, Ed. du Progrès, Moscou. 1978). Embora menos recente do eme estas obras, o vol. 3 da Geschichte der Philosophie, dirigido por M. A. Dynnik e outros, Deutscher Verlag der Wissenschaften, Berlin, 1961 (trad.: Historia de la filosofía, vol. 3, Grijalbo, México, 1962), não perdeu o seu interesse para o estudo da formação 


\section{Antonio Sérgio}

É possível que o simples enunciado que fez das suas teses se afigure a Sérgio como a evidência mesma. Mas será de facto coisa perfeitamente evidente, que não demanda explicação nem demonstração, o dizer que «todo dialecta há-de pensar com Antero que 'o universo análogo no fundo ao espírito, só pelas suas ideias imanentes existe e se governa'»?

Antes de prosseguirmos permita-se-nos aqui, num breve parênteses, uma precisão necessária. Repare-se: o que ocorre é isto: a crítica que Sérgio faz do que chama «materialismo histórico» é, no esencial, justa. Simplesmente, não é isso o materialismo histórico de Marx, de Engels, de Lénine.

A crítica que Sérgio faz do que chama «teoria do reflexo» é, no essencial, justíssima. Simplesmente, a teoria dialéctica materialista do reflexo de Marx, de Engels, de Lénine não é isso.

filosófica do pensamento de Marx e Engels do ponto de vista da história das ideias integradas nos seus quadros sociais e ideológicos. - Em particular acerca de um ponto específico levantado por Sérgio, e quanto a nós inexactamente, respeitante aos aspectos lógicos e epistemológicos do problema das contradições objectivas e subjectivas posto pela lógica dialéctica materialista como parte do problema geral da relação entre as leis lógicas formais e as leis dialécticas do pensamento e do papel que desempenham estas leis no conhecimento, e designadamente sobre a relação entre o princípio de interdição da contradição em logica formal e o princípio dialéctico do reconhecimento da contradição, e sobre a irredutibilidade da concepção dialéctica materialista das contradições aos esquemas da lógica idealista, veja-se nomeadamente o volume Dialéktika i lóguika. Zakóny mychléniia, de um colectivo de autores dirigido por B. M. Kédrov, Moskvá, 1962. Dois capítulos valiosos e densos de esta obra (pp. 267-334) redigidos por I. Elez e Kédrov bem assim como um capitulo de extrema importância do livro de E. V. Ilienkov, Dialéktika abstráktnogo $i$ konkrétnogo v «Kapitale» Marksa, Moskvá, 1960, pp. 112-185, sobre o movimento do pensamento que se eleva do concreto ao abstracto e do abstracto ao concreto, e sobre as relações do lógico e do desenvolvimento histórico real (capítulo que convém 1er relacionando-o com o trabalho de M. M. Rosental, traduzido para francês com o título Les Problèmes de la dialectique dans "Le Capital» de Marx, Paris-Moscou, 1959), podem hoje ler-se em português: A Concepção Dialéctica Materialista das Contradições e Contradições Objectivas e Contradições Subjectivas, e A Dialéctica do Abstracto e do Concreto em «O Capital» de Marx, entre outros estudos, na colectânea Marx e a Dialéctica Materialista. Prefácio, selecção e organização de Vasco de Magalhães-Vilhena, na colecção por nós dirigida «Dialéctica», vol. 8, Livros Horizonte, Lisboa. Ver também os trabalhos mencionados algumas notas antes sobre a lógica materialista. 
A crítica que Sérgio faz do que designa por «dialéctica materialista» não é o que Marx, Engels ou Lénine entendem por dialéctica materialista.

Isto, dizemos nós. Mas não se trata tão-somente de uma opinião pessoal, subjectiva. Comprovam-no suficientemente os textos dos respectivos autores, como é fácil certificar-se quem quiser dar-se ao cuidado de o fazer $\left({ }^{125}\right)$. Será claro, simples e preciso? Como diria Sérgio, cada um que releia atentamente os textos, e que decida por si.

Revertamos agora à questão em que há pouco ficáramos. A saber: o entender Sérgio ter sido um acidente deplorável haver Marx sustentado «uma metafísica com preconceitos materialistas e que se intitula materialista, sendo de facto idealista nas suas pressuposições fundamentais». Por aqui se adverte, ao que pensamos, e nisto estriba o essencial da argumentação sergiana, como a sua oposição de princípio- e do mesmo passo a sua aceitação do que nela vê de válido - à concepção materialista da história, se prende logicamente à sua oposição, também de princípio e de raiz, à concepção dialéctica materialista. Ambas as oposições têm um fundo comum: a denegação do materialismo, o idealismo estreme, consequente, de António Sérgio.

Está aqui o cerne da questão. Vejamos, pois.

As raízes do pensamento histórico sergiano são, em nosso entender, no essencial, de ordem filosófica, e não propriamente historiográfica. O mais profundo sentido do idealismo histórico-social de Sérgio é de isso cabal testemunho.

Se bem vemos, há por conseguinte que situar adequadamente a historiografia sergiana $\left.{ }^{128}\right)$. Para a inteligir apro-

$\left({ }^{12<s}\right)$ Para uma visão global dos textos básicos, em tradução correcta, podem ver-se: Reader in Marxist Philosophy. From the Writings of Marx. Engels and Lenin. Selected and Edited with Introductions and Notes by Howard Selsam and Harry Martel, International Publishers, New York, 1963; Dinamics of Social Science. A Reader in Marxist Social Science. From the Writings of Marx, Engels and Lenin. Selected and Edited with Introduction and Notes by Howard Selsam, David Goldway and Harry Martel, International Publishers, New York, 1970; e K. Marx, F. Engels, V. Lenin, On Historical Materialism. A Collection, Progress Publishers, Moscow, 1972.

(1M) Destaque especial merece, do ponto de vista do historiador profissionai, o livro bem informado e sagaz de Victor de Sá, $A$ Historiografia Sociológica de António Sérgio, voi. 34, Série Pensamento e Ciểncia, da prestigiosa «Biblioteca Breve», dirigida por Álvaro Salema, 
priadamente é impossível descurar o seu suporte e fundamento: o idealismo histórico-social. Base em que assenta o fio condutor inteligível de toda ela. Não o têm visto assim os historiadores que meramente como historiadores se debruçaram sobre os escritos históricos de Sérgio e por isso não têm sido eles considerados à sua verdadeira luz e entendidos no que para Sérgio era o essencial, e o que, no fundo, faz da historiografia de Sérgio, digamos assim, um «caso» à parte na tradição histórico-cultural do país. Isso o demarca de todos os demais, sem exceptuar aqueles de quem ele, à primeira vista, parece estar mais próximo: um Herculano, um Antero (o de As Causas da Decadência), um Oliveira Martins. Para já nada dizer de um Jaime Cortesão de quem, na verdade, dista tanto e de há tanto tempo: as suas primeiras discrepâncias datam pelo menos de 1913, de uma polémica travada entre ambos (e a que não é habitual fazer referência) sobre a concepção da história nacional, nas páginas de $A$ Vida Portuguesa ${ }^{127}$ ).

Neste sentido, a obra historiográfica de Sérgio não se situa de modo algum num qualquer veio da tradição portuguesa. Muito ao invés de alinhar numa qualquer tradição histórica nacional desenvolve-se antes no essencial contra ela. Marca nessa tradição, pelo contrário, um caso ímpar, um momento excepcional, decisório. E de aí, essencialmente, o não ter sido compreendido no seu próprio tempo, e muitos ainda $\mathrm{o}$ não compreenderam hoje. Essa, e não outra, a seus olhos - e outrossim em nosso entender - a sua contribuição, por ven-

instituto de Cultura Portuguesa, Lisboa, 1979. Cf. as páginas igualmente consagradas a António Sérgio por Victor de Sá no seu volume Esboço Historico das Ciências Sociais em Portugal, na mesma «Biblioteca», voi. 17, Lisboa, 1978, esp. pp. 89-99. Anos antes, Joel Serrão publicou um breve ensaio, o primeiro que saibamos, sobre um tema afim: Para uma interpretação do ensaísmo histórico-pedagógico de intórno Sérgio, in Temas de Cultura Portuguesa, ed. Ática, Lisboa, 1960, pp. 169-184, e também ulteriormente do mesmo autor uma bela comunicação com vistas penetrantes: $O$ Lugar da história no pensamento de António Sérgio, in Homenagem a António Sérgio, Academia das Ciências de Lisboa, 1976, pp. 45-52.

$<12 \mathrm{~T})$ Fundamentalmente a polémica centra-se nos dois seguintes artigos: Jaime Cortesão, «O Parasitismo e o Antí-historismo. Carta a Antonio Sérgio», $A$ Vida Portuguesa, n. 18, Porto, 2 de Outubro de 1913, pp. 137-139, e António Sérgio «Ö Parasitismo Peninsular. Carta a Jaime Cortesão", ob. cit., n. ${ }^{\circ} 20$, Porto, 2 de Dezembro de 1913, pp. 153-159. O artigo de Sérgio é particularmente significativo e esclarecedor àcerca do posicionamento quanto a um ponto fulcral da história portuguesa, e, de certo modo prenuncia o que virão a ser algumas das suas teses históricas essenciais e deixa antever o que será a sua Antologia dos Economistas Portugueses. 


\section{Idealismo Historieo-Social}

tura essencial, entre nós, para a historiografia do nosso tempo: que não há, nem pode haver, reflexão histórica consequente sem sagaz e profunda reflexão filosófica. Não há, não pode haver ciência histórica, no sentido pleno do vocábulo, sem raízes e implicações filosóficas. O que aliás de modo algum significa a aceitação de uma qualquer filosofia da história.

Se António Sérgio levou a cabo ensaios de feição histórica foi porque as circunstâncias - sempre impulsoras, no seu caso, da actividade, digamos «histórica», num sentido particular do termo-, a isso o compeliram (128) e porque mais do que o objecto ou as matérias sobre que incidiam as suas investigações - ele próprio o disse vezes sem conta -, o que para ele contava em primeiro de tudo, para além mesmo do acto de pedagogista social, mas conexo com ele, era, numa unidade de propósitos e de meios, «o estilo do pensar e a disciplina do exame» $\left({ }^{129}\right)$, a exigência problemática, a impostação de problemas reais, a busca da inteligibilidade plena e da plena racionalidade, «pelo valor que em si mesma assume».

«Pouco me interessaria [a ele que não visava ser historiador nem erudito, e muito menos erudito arquivista, - como ao tempo, entre nós, se entendia sobretudo a função do historiador] a atitude de espírito com que um povo considera a sua própria História, se ela não influísse na atitude de espírito com que ele se orienta no seu viver presente. Mas influi. ... Repito: o que me interessa não é a História; mas somente a mentalidade com que nós a abordamos: por isso, e só por isso, tenho eu escrito sobre temas de história». E mais: «Repito: tão só pensando no que está para vante olho eu para a esteira da nossa nau» $\left({ }^{13 \circ}\right)$.

E noutro passo escreve: "Quisera eu que se renovasse a historiografia nossa [sobretudo] pelo surto de ideias fecundas,- por análises e por hipóteses, por explicações e interpretações» $\left({ }^{1 \mathrm{~S} 1}\right)$.

A história é, em suma, para Sérgio, um entre muitos dos objectos - mas objecto relevantíssimo - da problemática intelectual. E precisamente relevantíssimo porque primacial para

(1M) Cf. Cartas de Problemática, Carta n. ${ }^{\circ} 10$, ed. Inquérito, Lisboa, 1953, p. 2.

(1J9) História de Portugal, I: Introdução Geográfica, ed. Portugália, Lisboa, 1940, p. 17.

(130) Ensaios, IV, ed. «Seara Nova», Lisboa, 1934, pp. 256-257 (o itálico é de Sérgio). Este texto retoma e reforça o que Sérgio escrevera já em «Historicismo arquivístico, Miragem Retórica e Problemática Intelectual», Seara Nova, XI, n. ${ }^{\circ} 310,1932$, p. 341.

(m) «Historicismo Arquivístico, Miragem Retórica e Problemática Intelectual", Seara Nova, XI, n. ${ }^{\circ} 310,1932$, p. 343. 
a efectiva compreensão do presente, para a sua radical transformação e humanização, e consciente preparação do porvir.

Ora al está. O ponto, para Sérgio, é «a consciência da problemática» (132), «a não escamotação dos problemas» (133) da realidade portuguesa passada e presente, e, consequentemente, «emancipar pela problemática» $\left({ }^{134}\right)$.

E em historia, demandar a inteligibilidade quer dizer, segundo Sérgio, buscar «uma maior inteligibilidade do viver de outrora» $\left({ }^{135}\right)$.

Neste ângulo, foi Sérgio um ensaísta das ciências sociais, ou ciências humanas como por então perferentemente se dizia. Se se quer situar a posição de Sérgio nas ciências sociais, e mais particularmente a historiografia sergiana, há que precisar antes de mais uma nítida e constante linha geral de pensamento neste domínio. E não é fácil, contrariamente ao que à primeira vista pode parecer. E porquê isso?

Haverá, de facto, um segredo da unidade do seu pensar, uma vez sabido que ele pouco ou mesmo nada variou ao longo dos anos? Pois não será este o ponto básico da vera e complexa problemática que a sua própria obra levanta?

A problemática sergiana implícita na textura da sua obra - eis aqui um ponto a considerar. Ora, essa problemática - que comanda tudo o mais - é de vária ordem.

António Sérgio foi impenitentemente avesso, e desde os primeiros passos até final, à «romântica maneira de conceber a História» (como aliás de conceber tudo o mais), que, entre nós, alastrava em torno e que formava - ele o disse - a mentalidade reinante. De aí a sua vivaz reacção contra os fantasmas de um certo «romantismo» (136) com a sua «nubivaga retórica», os fantasmas e os mitos do «saudosismo», do messianismo, do sebastianismo, do bandarrismo e do seiscentismo, os «desvairos da mente nacionalista» $\left({ }^{137}\right)$, «as larvas tumula-

(132) História de Portugal, 1: Introdução Geográfica, Lisboa, 1940, p. 17 . 1952, p. 5 .

C $\left.^{33}\right)$ Cartas de Problemática, Carta n. ${ }^{\circ}$, ed. Inquérito, Lisboa, 1940, p. 26.

$\left.C^{34}\right)$ Ob. cit., Carta n. ${ }^{\circ}$ 9, 1953, p. 6.

(136) História de Portugal, I: Introdução Geográfica, Lisboa,

(136) São significativos, no primeiro tomo dos Ensaios, de 1920, os títulos dos três últimos ensaios do volume: «Interpretação não romântica do sebastianismo» (pp. 261-278), "A Conquista de Ceuta (Ensaio de interpretação não romântica do texto de Azurara)» (pp. 279-305) e «O Caprichismo romântico na obra do Sr. Junqueiro» (pp. 306-434) — datados respectivamente de 1917, 1919, e 1920.

(3T) Por ex.: «Em Torno da 'História Trágico-Marítima'», Ensaios, VIII, Guimarães Editora, Lisboa, 1958, p. 94. 


\section{Idealismo Histórico-Social}

res» em suma dos «Espectros» de toda a sorte, transmitidos por tradição e circunstâncias permanentes, as «miragens retóricas» (já no passado, já no presente) e a sua incidência persistente, embargando senão impedindo, uma genuína e vera «Problemática intelectual», desatendida e mesmo desprezada pela historiografia lusíada, e de que há real mister.

A sua oposição, como também o disse e repetiu vezes sem conta, «não era a de um historiador contra historiadores» $\left({ }^{138}\right)$. Mas a de opositor a uma atitude de espírito, a uma certa mentalidade passadista: a «mentalidade meramente arquivística» (139), a de todo aquele que «não pode compreender uma atitude mental que não seja a do puro eruditismo arquivístico» $\left({ }^{14^{\circ}}\right)$. Era acima de tudo o tipo de mentalidade então dominante, herdada em grandíssima parte, e não só, da tradição historiográfica «positivista», - entrada em crise nos meios universitários da Europa culta pelo anos 20-30, - o que Sérgio condenava nos eruditos históricos do seu tempo, imbuídos da idolatria das «fontes», simples eruditos de feição empirista e positivistica, sem mentalidade crítica e problemática, que recusavam toda discussão teórica de historiografia, mas não isentos de preconceitos (e na primeira linha dos quais a positivistica pretensão de narrar «como é que as coisas efectivamente se processaram historicamente», de que «os factos falam por si»), eruditos (como ele diz algures), «que são muito pontuais no que não importa» ( $\left.{ }^{141}\right)$, sem «consciência das dificuldades para que é preciso olhar» $\left({ }^{142}\right)$; era, numa palavra, o espírito da «miragem» retórica que eles inculcavam que Sérgio impugnava com toda a sua firme veemência: era, como Keyserling, citado por Sérgio, dissera, «o carácter arquivístico do seu método histórico», «a sua inclinação para o historicismo e o filologismo formalistas». O que Sérgio, em suma, sobretudo verberava nas «elites» que imperavam na «erudição» histórica do seu tempo era «a falta do sentido da problemática intelectual» $\left({ }^{14 \mathrm{~S}}\right)$. Ou ainda: «a sabínchonice filológica e arquivística» dos que, sem capacidade intelectual, sem «o dom de conceber e organizar ideias», laboriosamente se afanam nos arquivos sobre os códices em busca de alega-

(138) «Historicismo Arquivístico, Miragem Retórica e Problemática Intelectual», Seara Nova, XI, n. ${ }^{\circ} 310,1932$, p. 341.

(13\#) Ob. cit., p. 341 .

(M0) Ob. cit., p. 343.

1952, p. 2.

(M1) Cartas de Problemática, Carta.$^{\circ} 4$, ed. Inquérito, Lisboa,

(143) Ob. cit., Carta n. ${ }^{\circ}$ 5, 1952, p. 3.

$C^{* 3}$ ) «Historicismo Arquivístico, Miragem Retórica e Problemática Intelectual», Seara Nova, XI, n. ${ }^{\circ} 310,1932$, p. 343. 


\section{Antonio Sérgio}

das «fontes» $\left({ }^{144}\right)$. Para dissipar as «miragens» e conjurar os fantasmas viu-se Sérgio arrastado (como disse) para o terreno dos historiadores da história pátria, terreno «que não era o meu, e que não tem o dom de me interessar em si, mas tão somente como factor e aspecto de um todo espiritual de que faz parte» $\left({ }^{145}\right)$.

Essa, por conseguinte, a natureza dos seus propósitos: «lançar certa luz [num dos] domínios das ideias fundamentais» $\left({ }^{146}\right)$, na ocorrência a história.

Para Sérgio, autor do ensaio significativamente intitulado «Espectros» ( ${ }^{147}$ ), (retomando a expressão do célebre drama de Henrik Ibsen), escrever história é «exorcismar os seus Espectros» (148), é travar «a luta da consciência de hoje com os fogos-fátuos do cemitério histórico» $\left({ }^{149}\right)$. E cita os Espectros, de Ibsen: «Não é só o sangue dos nossos avós que em nós corre, mas todas as ideias desfeitas, e as crenças mortas, e toda a geração das crenças mortas, - essas coisas que não vivem mas que nos dominam, e das quais não vingamos libertar-nos» $\left({ }^{\circ}\right)$. Contra esses Espectros se bateu Sérgio, contra a sobrevivência anacrónica de eles se define a sua concepção historiográfica $\left({ }^{151}\right)$. «A história - diz Sérgio - só deve servir para libertar-nos do passado» (152). Nada mais avesso ao «Espectrismo» que a sua maneira de conceber a história e a sua indagação. E não por um mero acaso. Há um fundo comum a isso e ao seu racionalismo de método. Um aspecto mais da coerência do seu sistema de ideias, do seu universo de um idealismo inteligente.

Os ensaios de historiografia, de Sérgio, são na verdade uma forma, quase diríamos privilegiada, do seu «ensaísmo polémico» $\left({ }^{153}\right)$.

(144> Cf. Páginas para serem meditadas. Sobre o filologismo. Trecho de José Ortega y Gasset, traduzido, precedido e acompanhado de significativas notas, não assinadas mas que sabemos serem de Sérgio. In: Seara Nova, XII, n. ${ }^{\circ} 341,1933$, pp. 77-78.

(145) Ensaios, IV, Lisboa, 1934, p. 257.

(14) Ensaios, VII, Lisboa, 1954, p. 231.

(14T) «Espectros», Atlântida, I, n. ${ }^{\circ}$ 11, Lisboa, 1916, pp. 1052-1067, Aditamento aos "Espectros», A Aguia, 2. a série, vol. XII, Porto, 1917, pp. 153-157. In: Ensaios, I, Rio de Janeiro, 1920, pp. 162-203.

(14S) «Espectros», Atlântida, I, n. ${ }^{\circ} 11$, Lisboa, 1916, p. 1060.

(14i) Ob. cit., p. 1061.

(150) Cit. in ob. cit., p. 1064.

(151) Ver ainda, anos volvidos, a condenação do espectrismo na compreensão da história nas «Divagações Proemiais» da sua História de Portugal, I, Lisboa, 1941, p. 27 e 29.

(lin) Ensaios, II, ed. «Seara Nova», Lisboa, 1929, p. 227.

Lisboa, 1953, p. 3.

(ira) Cf. Cartas de Problemática, Carta n. ${ }^{\circ}$, ed. Inquérito, 


\section{Idealismo Histórico-Social}

«Idealista de acção», como a si pròprio se designou - $\mathrm{e}$ isto precisamente num escrito seu de marcada feição histórica (154 ) - escrever, e designadamente escrever sobre temas de história, era para ele uma maneira específica, muito própria sua, de actuar. De intervir na vida político-social da nação. Ele que mesmo quando escrevendo sobre temas históricos não se considerava nem se propunha ser - ou ser apenas historiador, nunca ambicionando fazer «um trabalho de historiador na pura estritez do vocábulo, senão que mero escorço de interpretação sociológica», "senão que na atitude do observador sociólogo, do homem que luta pela emancipação do povo» (155); escrever nesse sentido é pois, basicamente, facultar temas de meditação sociológica, para incitar um consequente agir. Historiar para compreender o viver da grei de outrora é, ao fim e ao cabo, lutar pela grei do porvir. Ele o disse sem rodeios, ainda na Carta-Prefácio: «busco preparar o que tem de vir» $(156)$.

E também: «Só se me afigura que nos serão de préstimo os historiadores que se ocupem de estudar no passado tudo aquilo que se liga por feição directa com os problemas actuais da sociedade humana, ou que historiem de maneira que nos eduque $o$ espírito para a conveniente solução dos problemas de hoje» (157). E foi isso o que Sérgio sempre nos declarou propor-se: chamar os que o lêem à consciência da realidade portuguesa. E de resto, é o que é consentâneo com o prospectivismo do seu idealismo de acção.

Foi propriamente, ao que tudo parece indicar, num movimento de resposta aos que o acusavam de seguir as teses do materialismo histórico nos seus primeiros escritos $\left({ }^{158}\right)$ de

(1M) Testemunhos Históricos. O Desejado. Documentos de Contemporâneos de $D$. Sebastião sobre este mesmo rei $e$ a sua jornada de Africa, precedidos de uma Carta-Prefácio a Carlos Malheiro Dias, Liv. Aillaud e Bertrand, Lisboa, 1924, p. XVII.

(155) Ensaios, VIII, Guimarães Editora, Lisboa, pp. 8-9.

(15s) Testemunhos Históricos. O Desejado, Lisboa, 1924, pp. XVI-

-XVII.

(15T) Ensaios, VIII, Guimarães Editora, Lisboa, 1958, p. 245.

(15s) Foi de facto Sérgio quem disse, em próprios termos, ser seu propósito «levar a estudar a nossa história à luz das determinantes económico-sociais, como nas ditas Considerações Histórico-Pedagógicas [impressas em 1915] (e de ai por diante noutras obras)» (Cartas do Terceiro Homem, Porta-Voz das "Pedras vivas" do "País real", 3. a série, ed. Inquérito, Lisboa, 1957, p. 29; agora in Democracia. Obras Completas, Sá da Costa Editora, Lisboa, 1974, p. 275). Mas de tais dizeres não é lícito obviamente concluir, sem reservas, - e, por sua parte, Sérgio não foi omisso em tal ponto - seguir na esteira da corrente do materialismo histórico. A responsabilidade principal do equívoco não lhe cabe; está, sim, na desatenção com que o leram. 


\section{Antonio Sérgio}

teor histórico relativos a acontecimentos do passado com repercussões duráveis na existência nacional, e em resposta também aos que - por vezes os mesmos - sustentavam explícita ou implicitamente uma concepção histórica no essencial «positivista» e, no fundo, epistemológicamente «realista» (159), que António Sérgio foi sobretudo levado a aprofundar e a precisar para os seus leitores o essencial da temática e da problemática do seu idealismo na história. Embora outras, muito diversas, - mas não vêm aqui para o caso - tivessem sido as razões que o convenciam da relevância das «exigências do económico» (a expressão é sua) no viver dos povos.

Em primeiro de tudo, um ponto há em que cumpre atentar: a sua reflexão histórica, como dissemos, assenta, de princípio a fim, numa reflexão filosófica. Nessa perspectiva há, pois, que situar adequadamente a historiografia sergiana. Situá-la é, em suma, buscar o seu significado intrínseco. E qual seja esse significado intrínseco não é, para nós, ponto questionável. É o seu idealismo histórico-social, elemento constitutivo, não isolável, do seu idealismo crítico.

Assim, pois, a postura ideológica de Sérgio é clara e insofismável. Não há na sua maneira de conceber a história o que quer que seja de positivista, de realista ou de materialista. A sua concepção é a de um estreme idealismo na história. Ainda mesmo quando considera os motivos económicos dos factos histórico-sociais - sem excluir os próprios factos de natureza económica - considera-os de um prisma idealista sem falhas. Mais: o seu idealismo histórico-social é um idealismo intransigente, inteiramente consequente e radical. Ao mesmo título e do mesmo modo que todo o seu idealismo filosófico. É a mesma a sua natureza epistemologica. São as mesmas as suas raízes gnoseológicas e sociais.

A atitude que Sérgio tomou em relação ao materialismo histórico assinala-se sobretudo em dois momentos — «momen-

C") «....O idealismo, ou seja a tese de que a afirmação do ser se estriba na determinação do ser como conhecido, em oposição ao realismo, que arraiga numa pretensa intuição do ser como ser. Reflitamos a partir de aqui, a ver se encontramos uma intuição do ser que nos faça de facto sair jamais da correlação de um sujeito e de um objecto, e chegar portanto ao absolutismo do objecto, que é o carácter do realismo» (Pequeninos pontos que o acaso vai trazendo $e$ que submeto à meditação de jovens amigos..., in Seara Nova, XVII, n. ${ }^{\circ} 510,1937$, pp. 105-106.) «Eu rejeito em tudo o realismo» (In: Herculano, Sobre História e Historiografia. Selecção, prefácio e notas de A. Sérgio, ed. «Seara Nova», Lisboa, 1937, p. 13). 


\section{Idealismo Histórico-Social}

tos», mas não «fases» $(160)$ - : num primeiro momento, em reacção aos que, não tendo compreendido o fundo do seu pensamento ao tratar da importância do económico na história, o identificaram com o materialismo histórico, - e de aí o ter de insistir sobre o que fundamentalmente o demarcava da concepção histórica (quando não até da filosófica no seu todo) de Marx e de Engels; num segundo momento, em reacção também, mas de esta feita aos que, julgando defender as posições de Marx, mas sem as haverem entendido a pleno, criticavam as ideias que Sérgio explanava para frisar exactamente o seu idealismo histórico-social.

Foi face aos que viram na sua maneira de conceber a história - tão diversa da que então era corrente nas nossas letras, - e tanto a história social e política como a cultural ou até a económica, uma concessão sua à concepção materialista da história e mesmo a posição de um adepto declarado do materialismo histórico de Marx e Engels, que Sérgio, replicando aos que assim pensando o acusavam, afinou e precisou as pedras angulares do seu idealismo histórico-social.

O singular, porém, é Sérgio não se ter apercebido que nem tudo o distanciava tanto como supunha da concepção filosófica marxengelsiana quando entendida a rigor. $\mathrm{O}$ que, quanto a nós, se compreende sem perplexidade se se recorda o ditame de fina observação de V. I. Lénine, que tantos desconhecem e que Sérgio no entanto conhecia, como sabemos: «o idealismo inteligente está mais próximo do materialismo inteligente do que do materialismo inepto» (161). E por materialismo inepto ("glúpyi»), Lénine entendia, como ele mesmo esclareceu, um materialismo vulgar, não desenvolvido, fruste, grosseiro - aquele precisamente que Sérgio por sua parte também impugna, mas que inadvertidamente confunde com o outro. E de este modo, Sérgio, em vez de visar directamente «o outro», visou tão-só «uma sombra do outro».

De certo esse mito não foi só ele que o ergueu por suas mãos. Era o mito de que se falava em contra e também em pro. Mas Sérgio recusou-se, obstinadamente, a distinguir. Ele que tantas vezes disse chamar «cultura», no sentido absoluto do termo, à capacidade «de nos desprendermos de todos os limites que tendem sempre a impor-nos as condições parti- * 5

\section{Lisboa, 1954, pp. 1-2.}

$\left(^{16 \circ)}\right.$ Cf. Cartas de Problemática, Carta n. ${ }^{\circ}$ 10, ed. Inquérito,

(161) «úmnyi idealízm blíje $k$ òmnomu materialízmu, tchem glúpyi materialízm» - V. I. Lénine, Filosófskie tetrádi (Cadernos Filosoficos), in Pólnoe sobránie sotchinénii, $5^{\circ} \mathrm{izd}$. (Obras Completas, 5. a ed.), t. 29, Moskvá, 1963, p.248. 
culares de espaço e de tempo, do «aqui» e do «agora» (162), deixou, na ocorrência, que as condições particulares do meio e do momento se lhe impusessem. Nada impedia que o tivesse feito? Sim, havia: a própria conjuntura, e nós bem sabemos o que ela era na altura, nesses negros anos de cerrado obscurantismo. E o mal é que Sérgio nem sempre soube - ou não pôde - negar-se (como ele de resto aconselhava que era mister negar) a embrenhar-se nesse matagal polémico, quando a ele o atraíam.

Seja como for, o certo, contudo, é que se uns o repeliram como «materialista histórico» (163), outros o repeliram também precisamente, e a revés, como contraditor de esse mesmo «materialismo histórico» que nem uns nem os outros, no confuso ambiente ideológico do tempo, se mostraram capazes de compreender a pleno.

Materialista histórico, Sérgio? Em caso algum.

Foi precisamente, na verdade, retorquindo ao que, na sua perspectiva, designa por «a dogmática dos chamados 'materialistas históricos'» que Sérgio afirmou sem margem para equívocos: «eu sou em tudo fundamentalmente idealista» (164). «Os factores dos acontecimentos históricos — disse ainda são as ideias dos homens que intervêem neles». E logo acrescenta: «Sim, as ideias: .... presumo que as ideias são criações da psique, e que por meio das ideias que por nós concebemos é que os objectos do pensamento são criados. Por outras palavras: que só há objectos para a inteligência depois de a própria inteligência os haver criado» $\left({ }^{165}\right)$.

«Idealista de acção» como disse, a reflexão filosófica com intenção social, é, a seu ver, em derradeira análise, determinante da acção. Por isso que «a nossa mente é dinâmica, os nossos ideais actuam» (16s). Lema entre todos relevante do seu «humanismo crítico» (167). A «dialéctica própria do idealismo político (ou do idealismo moral)» — os termos são de Sérgio (168) —é muito afim da que ela própria vislumbra no processar mesmo da história, se é que, na unidade unificante da consciência sergiana, não é tudo, ao fim e ao cabo, um só

${ }^{(16 J)}$ Cartas do Terceiro Homem, 3. a série, ed. Inquérito, Lisboa, 1957, p. 135.

(183) Cं. Ensaios, II, ed. «Seara Nova», Lisboa, 1929, p. 255.

(1\#4I «Explicação e Subsunção sob Fórmulas Gerais», Aqui $e$

Além, Revista de divulgação cultural, n. ${ }^{\circ}$, Lisboa, 1945, p. 21.

(M0) Ob. cit., p. 20.

(168) Ensaios, VIII, Guimarães Editora, Lisboa, 1958, p. 219.

("'") Ensaios, VII, Europa-América, Lisboa, 1954, p. 235.

(1Ss) «Ora até que enfim!», Seara Nova, VII, n. ${ }^{\circ} 170,1929$, p. 24. 


\section{Idealismo Histórico-Social}

todo, imensa «teia das relações racionais». «Sempre que um homem quer realizar uma ideia, porém, topa em condições materiais circunstantes, que o desviam da linha em que pensou seguir, ou que determinam a linha em que ele terá de seguir. Condições circunstantes de estrutura geográfica; condições circunstantes de ambiente clímico; condições circunstantes de posição no globo; condições circunstantes de natureza económica; condições circunstantes de vizinhança humana... Circunstâncias condicionantes, não factores de história: factores, propriamente, são-no sim as ideias» (169).

Acontece, porém, que Sérgio não esclareceu o que entende por «condições materiais circunstantes» que «desviam [o homem] da linha em que pensou seguir, ou que determinam a linha em que ele terá de seguir», nem tão-pouco porquê nem como, sendo idealista, considera materiais essas condições circunstantes ou ainda o que entende, como idealista histórico que radicalmente se opõe ao materialista histórico, por condições materiais circunstantes de natureza económica $\left({ }^{170}\right)$. Ou muito erramos ou algo de importante ficou aqui por esclarecer.

E no caso das suas indagações concretas de teor histórico, essas «condições circunstantes de natureza económica» como as concebe Sérgio no desenrolar do processo social?

Não passando abruptamente, claro, por um processo mecânico e com o seu quê de automático, da necessidade material económica aos acontecimentos históricos que se relacionam com ela, mas detendo-se na interpretação de uma ideia: a ideia de satisfazer por determinada forma, e não por qualquer outra, o imperativo económico. A «interposição da ideia», de uma «certa atitude mental» que Sérgio muito justamente sublinha - outros a quem Sérgio supôs estar-se opondo diriam: a esfera ideológica — é precisamente o que haviam esquecido os prosélitos mecanistas do «sociologismo vulgar» que aderiam ao princípio — taxativamente recusado aliás tanto por Marx como por Engels ou por Lénine, e não só por eles — de um determinismo estrito da esfera económica na actividade humana, descurando assim o exame aprofundado e minucioso da problemática relativa às formas da consciência social, à interacção complexa e mediatizada da base e da superestrutura. No caso do ataque a Ceuta, por exemplo, que Sérgio analisou

$\left(^{\left(6^{\circ}\right)}\right.$ Explicação e Subsunção sob Fórmulas Gerais, Aqui e

Além, Revista de divulgação cultural, n. ${ }^{\circ} 3$, Lisboa, 1945, p. 20.

(1T0) Os grifados são nossos. V. de M.-V. 
detidamente não só no ensaio célebre de 1919 (m), que tanta celeuma levantou, como depois em variadíssimos outros escritos (172), entre a necessidade económica (que na hipótese aventada por Sérgio seria a carência de cereais entre nós) e a operação militar, Sérgio concebe a «mediação» de uma certa «ideia» criada pelo espírito dos que se defrontavam com o problema, e escolhida entre tantas outras que possivelmente ocorreram, como a que se lhes afigurava, com razão ou sem ela (a prova de constrataria dá-la-ia o sucesso ou o malogro da empresa e o alcançar do fim proposto) como a mais exequível dentre as mais aptas a satisfazer, consoante os seus interesses de classe - a burguesia comercial-marítima, - as necessidades vitais, económicas, que estavam, em última análise, na base do seu proceder.

A posição de Sérgio na ocorrência é - mas talvez só hoje- de diáfana clareza, e sem dúvida por influência de uma justa compreensão do materialismo histórico. Mas não foi assim ao tempo. Na confusa situação ideológica imperante, sobre a qual se fazia tão pesadamente sentir o obscurantismo salazarista-fascista, difícil senão impossível seria evitar as ambiguidades. E a recepção da obra de António Sérgio, tão rica e tão variada, inegavelmente difícil, difícilima mesmo na sua exacta interpretação, apesar da sua aparente claridade, não podia escapar ao perigo da ambiguidade. E essa ambiguidade, a aflorar ou implícita, por vezes acaso até intencional, não podia necessariamente deixar de suscitar um certo número de equívocos. O maior dos quais, talvez, o alegado «materialismo histórico» da sua historiografia.

O certo é que Sérgio não foi estranho a esse equívoco, o facilitou mesmo e, de certo modo, até lhe desbravou o caminho. São suas estas palavras, de 1950, que transcrevemos: «Na verdade, o problema é só este: se constitui em mim autocontradição patente (como muitos sustentaram .... o pro-

$C^{n}$ ) «A Conquista de Ceuta (Ensaio de interpretação não-romântica do texto de Azur ara)», Ensaios, I, Rio de Janeiro, 1920, pp. 279-305.

(m) Citamos: «As Duas Políticas Nacionais», Lusitânia, III, fase. 7, Lisboa, 1925, pp. 63-72 e fase. 8, 1925, pp. 227-238, Ensaios, II, ed. «Seara Nova», Lisboa, 1929, pp. 67-109; recensão crítica de «A Tomada e a ocupação de Ceuta», de Jaime Cortesão, Lusitânia, III, fase. 9, 1926, pp. 446-451; «A Formação de Portugal e a Política», de 1930, Ensaios, III, ed. «Seara Nova», Lisboa, 1932, pp. 285-296 e 421-423; "Ainda a política de Transporte e a política de Fixação», de 1929, ob. eit., pp. 297-303. É particularmente significativo estoutro ensaio de 1929: «Repercussões duma hipótese: Ceuta, as navegações e a génese de Portugal», Ensaios, IV, ed. «Seara Nova», Lisboa, 1934, pp. 229-275. 


\section{Idealismo Histórico-Social}

pôr interpretações sociais-económicas de acontecimentos capitais da nossa vida histórica rejeitando ao mesmo tempo qualquer sorte de ideário onde frise a etiqueta de doutrina «materialista». Por outras palavras: se toda interpretação económica na História tem de ser ao mesmo tempo uma interpretação materialista.... Nunca duvidei de que iria ser, no meu próprio país, o precursor de uma corrente de materialismo histórico. Fui-o pelo ensaio sobre a conquista de Ceuta; fui-o também pela orientação e intuito que presidiram à feitura da Antologia dos Economistas; fui-o (para um mais vasto público) pelo compêndio editado pela Casa Labor, sob o título de Historia de Portugal. E digo que não só de materialismo histórico, senão que também de um movimento de interesse pela história económica em geral... Sim: contava com ser na historiografia pátria o precursor de uma corrente de materialismo histórico, e muitíssimo me alegro de que por tal me apontem» $\left({ }^{173}\right)$.

Eis aí não propriamente a fonte de onde promanam tantos equívocos, visto que alguns de eles, como vimos, lhe eram já anteriores, datando da leitura de certas páginas das Considerações Histórico-Pedagógicas, de 1915 (como Sérgio o confirma, em $1929{ }^{(174)}$, mas o texto que parecia comprovar a justeza da sua interpretação, aos que viam na investigação histórica de Sérgio uma aceitação do materialismo histórico. Não passava no entanto de uma leitura desatenta e apressada. De facto, o texto que transcrevemos era logo seguido de estoutro: «Porém, nunca me contentaria de não passar desse nível; quer dizer: de só lançar esse germe às gestações da Grei. Eu desejava ser isso: mas queria mais e melhor: queria, sim, espevitar, - por toda a roda do horizonte, em todo o mar do saber; criar a possibilidade de uma revolução multimoda; revolver a cultura desde ponta a ponta; introduzir em tudo o racionalismo e a crítica; imprimir o impulso a uma investigação libérrima» $\left({ }^{175}\right)$.

Esse era, pois, o seu propósito. Não o de se deter no materialismo histórico, doutrina no essencial contrária ao seu idealismo histórico-social, como não cessou de o reafirmar. Idealimo que se alicerça, por que assim digamos, no seu idealismo gnoseològico.

(173) Notas de Esclarecimento, ed. Marânus, Porto, 1950, p. 51.

(1M) Numa Nota ao tomo II dos Ensaios, ed. «Seara Nova», Lisboa, 1929, p. 255 (Nota suprimida, aliás, na segunda edição de este tomo, de 1955).

(175) Ob. cit., pp. 51-52. 
Mas a exacta posição ideològica de Sérgio sobre o fundo da questão não foi entendida nem por uns nem por outros, como ele aliás bastas vezes o reconheceu. Uns só viram nela uma transparente prova da adesão de Sérgio ao materialismo histórico. Outros, ao revés, mal avisados da exacta concepção da doutrina, criam vislumbrar aí uma velada crítica a esse mesmo materialismo histórico. E Sérgio? Talvez não seja descabido supor que possivelmente inclinar-se-ia a pensar que com essa sua argumentação - parecendo desconhecer as porém célebres cartas de Engels dos anos 90, nomeadamente- estaria a introduzir um imparável golpe no terreno do adversário e a administrar uma prova mais do alcance do seu idealismo histórico. O facto inegável, contudo, é que nem para Sérgio - como nem tão-pouco para Marx, para Engels ou para Lénine - há qualquer contradição entre (os termos são de Sérgio) «as exigências económicas», «as determinantes económico-sociais», «o condicionalismo económico» e «a consciente finalidade humana».

Mas voltemos à ideia básica da doutrinação social de António Sérgio: o seu idealismo estrito.

Ora, o certo é que a filosofia implícita - quando não até claramente explícita - nos seus escritos de história sociológica é sempre, de facto, em rigorosos termos, uma filosofia idealista. Basta citar estas suas palavras: «A sociedade é um tecido de relações sociais que 'estão no pensamento como ideia'» (176). E quantas citas mais de teor análogo seria possível transcrever? Mas, de qualquer modo, o idealismo histórico-social de Sérgio - quem o pode duvidar? - está todo inteiro neste asserto, que, não sendo único nem mesmo raro, é por ventura dos mais explícitos.

Há, pois, para Sérgio, uma idealidade social ou uma «sociabilidade ideal» $\left({ }^{177}\right)$. E essa noção de «sociabilidade ideal»«a sociedade é uma ideia» (178) —é uma noção básica do idealismo histórico-social sergiano.

De aí decorre, num sentido, se bem que noutro já aí esteja subjacente, a concepção - radicalmente idealista, no

(176> Ensaios, VI, Ed. Inquérito, Lisboa, 1946, p. 50.

0") Cf. «Educação e Filosofia», Ensaios, I, Anuário do Brasil, Rio de Janeiro, 1920, p. 127. Cf. p. 130: «Dois espíritos constituem uma sociedade na medida em que os liga uma ideia de sociedade; a sociedade, em resumo, 'está no pensamento como ideia' [Camões]». Ver ainda pp. 132 e ss., 137-138, 144-153.

("*) Ob. cit., p. 145: «....a sociedade é uma ideia: ideia que existe nos indivíduos, e implica ideias de indivíduos. Mas estes, por um lado, estão também no pensamento como ideia, _ e como ideia que se constroi com a dos outros membros da sociedade.» 


\section{Idealismo Histórico-Social}

essencial, ela também - que Sérgio sempre pressupõe do «facto histórico».

Assim, diz Sérgio, há que saber que significa um «facto», um «facto concreto», «a realidade dos factos», que se entende em história pela palavra «facto», e que é para o historiador «o testemunho insofismável» da «objectividade das coisas»? Quais as razões que conduzem o investigador em história a acreditar na objectividade do «facto»? Consoante o pensar de Sérgio — perfeitamente consentâneo, há que reconhecê-lo, com toda a sua orientação idealista-, «a crença, em suma, na realidade do «facto», repousa na tíoerência de um sistema de ideias que nos permite interpretar uma aparência dada» $\left({ }^{179}\right)$. De aí asseverar verificar-se «que em última análise o único critério de objectividade do «facto» se reduz a um critério de representações de direito, e que teremos que recorrer, ao cabo de contas, à coerência da ideia de esse dito facto com um conjunto de várias outras ideias que se encontram relacionadas no nosso intelecto». O verdadeiro critério de objectividade dos «factos» «é sempre a coerência de um sistema de ideias que procura interpretar o que nos aparece ao espírito» $\left(1^{\circ}\right)$. «É «facto» - diz também Sérgio esclarecendo este ponto - o que se liga inteligivelmente com as outras coisas que consideramos «factos», o que é compatível com o conjunto dos «factos»............... A busca da verdade, ao cabo de contas, vem a ser a de uma estrutura total das ideias............................ Um

«facto» é sempre um conglomerado de ideias, e o critério da verdade é todo interior: a coerência de uma ideia com as demais ideias, da ideia de uma parte com a ideia de um todo, aspecto do Todo. Compreender uma coisa é relacioná-la com um todo, - ligá-la, em suma, com o todo estruturado que compreende a coisa. O total das ideias, sustenta uma ideia ....» (18X). Assim, para Sérgio, nenhum facto existe anteriormente à ideia, um «facto» é sempre um conglomerado ou entrançado de ideias, um denso tecido de relações inteligíveis, uma harmonia progressiva de ideias; na realidade das ideias e pelas ideias «se funda a realidade do 'facto'», só pela valia que lhe deu o raciocínio, a ideia se tomou um «facto». «A fé do arquivista na materialidade inconcussa, - exterior ao intelecto, independente da ideia, — dos longínquos «factos»

("*) «Historicismo arquivístico, Miragem retórica e Problemática intelectual», Seara Nova, XI, n. ${ }^{\circ} 310,1932$, p. 344. — Os itálicos são de Sérgio.

$\left(1^{\circ}\right)$ Ibidem.

(') Ensaios, IV, ed. «Seara Nova», Lisboa, 1934, pp. 271-272. 


\section{Antonio Sérgio}

que lhe são sugeridos pelos vagos [ou até minuciosos] testemunhos sobre os quais labora, não a tem o físico com a mesma energia a respeito dos fenómenos que lhe estão defronte (e que ele vê, controla, encaminha e mede) mas que sabe impregnados de uma multidão de ideias. ..O físico, em suma,

reconhece a idealidade do fenómeno físico, ao passo que o arquivista, muito ao contrário, só vê realidade no seu sonho histórico....» (182).

Ora bem. No espírito de Sérgio, a conclusão é, pois, irrecusável: à idealidade do fenómeno físico corresponde, logicamente, a idealidade do facto histórico. $\mathrm{E}$ ambas as teses são peças basilares do idealismo crítico sergiano.

Idealista outrossim a ideia de que, a rigor, a única verificação, provisória, de uma hipótese científica geral, de carácter sempre provisório por que essencialmente hipótese de trabalho, instrumento de investigação, é a própria coerência do conjunto de ideias em que exerce domínio essa teoria geral. Isto nas ciências do mundo físico como na interpretação histórica. A base das condições do sucesso histórico como do fenómeno físico realiza-se por análise regressiva e ascendente (e não da composição progressiva e descendente). A incógnita, aí, é o princípio geral a que se suspende o sucesso, o fenómeno: são as várias condições que condicionam o facto; sobe-se do fenómeno para a sua lei, do extremo do fio (onde jaz o facto) à escápula mental a que está suspenso. A análise regressiva, em suma, exige que se fantasie uma certa hipótese, não há indagação científica sem invenção de hipóteses. Simplesmente em história, na interpretação histórica, não é realizável a fase final da verificação da hipótese. E assevera ainda: «A justificação final de uma interpretação histórica é a soma de factos que nos fizer entender, é aquela fecundidade de que se mostrar capaz, é o número de relacionações que nos permite ver» (185). E Sérgio conclui sobre este ponto - ponto essencial entre todos de uma concepção idealista na história: «A única verificação de uma hipótese histórica (refiro-me às relativas aos movimentos gerais) é a própria coerência do conjunto das ideias a que preside a hipótese que se imaginou......... A base de objectividade [é] a própria satisfação

(18S) «Historicismo arquivístico, Miragem retórica e Problemática intelectual», Seara Nova, XI, n. ${ }^{\circ} 310,1932$, pp. 344-345. Os itálicos são de Sérgio.

(183) «Historicismo arquivístico, Miragem retórica e Problemática intelectual», Seara Nova, XI, n. ${ }^{\circ} 310,1932$, p. 341. 


\section{Idealismo Histórico-Social}

interior do espírito Toda objectividade é uma questão de direito, e funda-se na coerência intelectual interna» $\left({ }^{184}\right)$.

O ponto, para Sérgio, sempre foi que, convicto que o dado absoluto em nenhum campo se encontra, nem no mundo físico nem no social, e que toda a vida da mente é sempre um tecido de interpretações, como afeiçoava dizer, assim também no documento histórico, como na partitura musical, «'o que lá se acha escrito' nunca pode bastar e ser tudo» (185). Tudo pressupõe interpretação, toda interpretação implica invenção de hipóteses verosímeis que se enquadrem e conexionem com outras verosímeis hipóteses. E na sua sustentação recíproca estriba o que é, para Sérgio, o único critério da sua veracidade e, consequentemente, da objectividade histórica.

Consoante o seu ajuizar, tão pouco há ou pode haver adequação de ideias a factos, mas tão-só adequação de ideias a ideias. Epistemológicamente, Sérgio, nos seus próprios dizeres, nunca sai do âmbito da consciência.

O idealismo de Sérgio, idealismo «consciencista», o termo é seu (186), leva-o a reivindicar «esse fundamento de todas as coisas, essa única realidade incontestável, que é o facto de

consciência.......... Rejeito em tudo o realismo....................... Não me

fundo em suma em nenhuma coisa: fundo-me na consciência e nas relações. A sociedade, para mim, define-se em termos de consciência, por meio de relações intelectuais. Pertencer a uma sociedade, para o idealista, redunda em conceber um certo todo, - ou, melhor, uma relação, — de que nós constituimos um termo, e os outros sócios o outro termo. A sociedade é relação (187) ....Mantendo-nos no facto consciência e nas relações dadas na consciência, mantemo-nos sempre no que é concreto, no concreto máximo ... $\mathrm{O}$ «facto» histórico é que é abstracto...............As coisas são-nos dadas, a todos, nos

(184) Ob. cit., pp. 339-340. Sobre o que é, no ajuizar de Sérgio a base da objectividade para o idealista crítico, ver designadamente Ensaios, IV, ed. «Seara Nova» Lisboa, 1954, pp. 253, 270-273; cf. p. 254 o que escreve acerca da justificação final de uma interpretação histórica. Sobre tudo o que precede avultam as análises exaradas nas «Divagações Proemiais ao jovem leitor sobre a atitude mental que presidirá a este ensaio», antepostas ao tomo primeiro da sua História de Portugal, I: Introdução Geográfica, Portugália, Lisboa, 1940, pp. 22-29.

(155) Cf. o que escreveu no Prefácio ao livro do musicólogo João de Freitas Branco, Viana da Mota. Uma Contribuição para o estudo da sua personalidade e da sua obra, Lisboa, 1972 , p. 16. De relance, registe-se que este Prefácio é um dos derradeiros escritos de António Sérgio: Janeiro de 1958.

(188) Cf. Ensaios, VIII, Guimarães Editora, Lisboa, 1958, p. 225. $\left.{ }^{18 T}\right)$ E Sérgio remete aqui para Educação e Filosofia, no primeiro tomo dos seus Ensaios, Rio de Janeiro, 1920, pp. 113-162. 


\section{Antonio Sérgio}

nossos factos de consciência; portanto, longe de o facto de consciência ser um abstracto em relação às coisas, são as coisas que são abstractas em relação ao facto de consciência. As coisas, e as palavras da história. Abandonar a consciência para ir para a história - é abandonar a realidade para agarrar a sombra. Mas o estado de consciência, como tal, é sempre certo: é a certeza primária, a certeza directa básica» $\left({ }^{188}\right)$. genuíno.

É essa, no entender de Sérgio, a base de todo o idealismo

Assim, do mesmo modo que, epistemológicamente, no ajuizar de Sérgio, «a ideia do objecto reclama a de sujeito; a de que de si o objecto é relativo a um sujeito; a de que o objecto existe na trama do conhecimento graças ao acto do conhecimento» ${ }^{189}$ ), do mesmo modo, em seu entender, a ideia do «facto histórico» reclama a de sujeito conhecente do «facto», isto é, o historiador; de que de si o «facto» é relativo ao sujeito conhecente; a de que o «facto histórico» existe na trama do conhecimeento histórico, graças ao acto do conhecimento histórico do historiador; e, consequentemente, Sérgio rejeita tanto o «absolutismo» do «facto» como o «absolutismo» do objecto. A ideia do «facto», como a ideia do objecto, é correlativa da de sujeito, e portanto ambas são insusceptíveis de absolutizar-se. O «facto» para o historiador como o «objecto» para os demais cientistas são, no processo do conhecimento, em termos epistemológicos, no idealismo ideado por Sérgio, - contrário tanto à tradição positivista como à tradição do realismo gnoseològico, - construtos de relações inteligíveis de ideias. O subjectivismo da posição gnoseològica de Sérgio é evidente, no sentido em que um idealista dito objectivo entende o idealismo dito subjectivo. Mas não assim para o próprio Sérgio que, na perspectiva do seu idealismo crítico, de teor neo-kantiano, confere aos termos um sentido diferente, como é sabido - mas não talvez a preceito. Do seu particular ângulo de visão. Sérgio não aceitaria por exemplo, que se dissesse, - $\mathrm{O}$ que de um ponto de vista contrário ao seu é perfeitamente exacto - que ao absolutizar o princípio activo e criador no processo do conhecimento, confere uma importância decisória, não à existência real dos «factos históricos» a estudar pelo historiador, mas ao ponto de vista teorético que está na partida do trabalho criador de este. $\mathrm{Na}$

(188) «Idealismo e realismo. 'Morale d'abord' e 'Politique d'abord'», Seara Nova, VII, n. ${ }^{\circ} 163,1929$, pp. 296-297. 1955, p. 2.

(188) Cartas de Problemàtica, Carta n. 11 , ed. Inquérito, Lisboa, 


\section{Idealismo Histórico-Social}

linguagem de Sérgio, mas não na dos que de ele discrepam, dizer que o facto histórico exprime objectivamente uma realidade efectiva passada, que existiu deveras, independentemente do que de ela possam pensar os historiadores que a assimilam com base nos documentos históricos, expressão da consciência que de ela tiveram os contemporâneos, carece epistemológicamente de sentido. E isto porque epistemológicamente, a seu ver, o facto histórico como tal, a realidade histórica passada como tal, só existe enquanto objecto do pensamento, nunca em si («an sich»).

Para Sérgio, subsequentemente, a questão de uma relação do historiador com esses outros «factos» existindo independentemente do pensar do historiador é um falso problema, uma questão sem sentido. Não é por essa forma que Sérgio, em conformidade com o seu modelo gnoseològico próprio, posiciona o problema do conteúdo object ivo do processo histórico. É outra, em seu ajuizar, como vimos, a questão da objectividade. Radica, para tudo dizer, no princípio racionalista idealista da universal inteligibilidade.

Este é, para Sérgio, o fundo da questão. Aqui, por nossa parte, não nos cabe obviamente ir mais além. O tema, porém, aqui fica para reflexão $\left({ }^{190}\right)$.

Digamos apenas, para evitar equívocos, tão frequentes na interpretação do pensamento sergiano, que um ponto sobreleva entender perfeitamente. O idealismo crítico, o idealismo racionalista de Sérgio — «filosofia da consciência e do pensar reflexivo», nos termos mesmo de Sérgio (191), — e de que o seu idealismo histórico-social é, como vimos, parte integrante e da maior relevância, é um idealismo sui generis

$\left({ }^{18 \circ}\right)$ Elementos para uma reflexão, em contra-ponto, a partir de uma perspectiva radicalmente diversa da de Sérgio acima exposta, mas para a plena intelecção da qual a atenta reflexã̃o sobre a posição sergiana é a nosso ver de primacial importância muito embora não esgote o tema, topam-se nas suas Introduções a "Temas de Historiografia», de Hernâni A. Resende, de rara penetração e grande perspicácia, antepostas à tradução de estudos de Albert Soboul, Claude Gindin e M. A. Neiman, respectivamente sobre a obra historiográfica de Georges Lefèbvre, de Jean Mouvret e de E. H. Carr, os dois primeiros in História e Sociedade, n. ${ }^{\circ} 7$, Lisboa, 1981, pp. 6-16, 17-27, e n. ${ }^{\circ}$ 8-9, pp. 34-41; as Introduções de Hernâni A. Resende no n. ${ }^{\circ} 7$, p. 5 e no n. 8-9, pp. 29-34. No mesmo sentido das referidas introduções de Hernâni A. Resende, ver também, pela novidade do tratamento entre ${ }^{\wedge}$ nós, os estudos incluídos na colectânea História, Ciência Social, Prefácio, seleç̧ão e organização de Vasco de Magalhães-Vilhena, na colecção por nós dirigida «Dialéctica», vol. 6, Livros Horizonte, Lisboa, 1981, nomeadamente, mas não só, o estudo de Guennadi Ivanov, «Reflexão sobre o Conceito de «facto» em História», pp. 74-93.

(m) Cf. Ensaios, Is, Coimbra, 1949, p. 48. 
que, bem compreendido, não se confunde com outras orientações idealistas notórias, e em particular com algumas das que disputavam os favores dos meios universitários alemães dos meados do século XIX. Nomeadamente, aquela orientação que Sérgio denomina, com razão, «idealismo das ideias gerais»_ o hegeliano, fustigado justiceiramente, como admite Sérgio, por Marx, na crítica da «construção especulativa» da ideologia alemã (192). De aí o Sérgio ter afirmado sem rodeios, a adversários seus que o não entendiam a preceito, que essa crítica de Marx, com a qual concorda no essencial, não é de modo algum extensiva ao idealismo que lhe é próprio. E com inteira razão o diz: Há idealismo e idealismo - como (dizemos nós) há materialismo e materialismo. A crítica de certas variantes do idealismo — por exemplo o idealismo objectivo de Hegel - não fere necessariamente toda a argumentação de outros idealismos objectivos, e muito menos, obviamente, a de idealismos de teor subjectivo. Naturalmente, resta o facto de que um idealismo é sempre um idealismo, qualquer que seja a sua variante, e que a crítica de todo idealismo comporta elementos comuns, mas cada variante, pela sua própria peculiaridade, pressupõe e implica uma argumentação específica. E essa argumentação específica, própria do seu peculiar idealismo, raro tem sido entendida como Sérgio o desejaria. Sem entrar em delongas que levantariam longe e obviamente não têm cabimento aqui, há todavia que fazer ressaltar um ponto essencial. A saber: que quando Sérgio se refere à «vida do espírito», - $\mathrm{O}$ que frequentemente ocorre ao enunciar as teses típicas do seu idealismo epistemologico, - tem em vista não «a vida da consciência sensível do homem», mas «a vida da consciência intelectual do homem», capaz de elevar à norma objectiva, ao «fim incondicionado e absoluto», ao «cume do universal», e que, nesta perspectiva do seu racionalismo e humanismo críticos, doutrinas que (a revés do positivismo e do empirismo), mantém a distinção do ser e do dever-ser, «a busca científica da inteligibilidade das coisas pressupõe, no indivíduo que está buscando, a crença num dever-ser inteligível das coisas, e que o dever-ser, por consequência, não é coisa «científica», — pela mesma razão de que a fonte do rio,

(1S2) «Resposta a uma consulta», Seara Nova, XV, n. ${ }^{\circ} 466,1936$, pp. 154-155; Ensaios, VII, Lisboa, 1954, p. 241. Cf. Marx-Engels, Die heilige Familie, MEW, Bd. 2, Dietz, Berlin, 1958, pp. 59-63. - Sobre o conceitismo de Hegel e o idealismo de Sérgio, veja-se o que este escreveu em nota à sua edição crítica dos Sonetos, de Antero de Quental, Lisboa, 1943, pp. 259-260. 
por exemplo, se não pode scontrar na corrente do rio» (193). Funda-se, pois, este racionalismo, que se filia em Descartes e em Platão, (e ao contrário do falso racionalismo dos peripatéticos, que tem por alicerce a intuição sensível) na intuição intelectual e interna - a intelecção é facto de criação interna, espiritual, dinâmica — no acto criador de uma relação, $o$ qual se formula por um juízo; o juízo essencial, porém, é o de relação, não o juízo predicativo. O universal, para o racionalismo tal como Sérgio o concebe, encaminharse à realidade do mais denso concreto, visto na relacionação de tudo com tudo, esse ordume da universal relacionação, graças à unidade unificante do espírito que é a Razão. A Razão, para o racionalista idealista Sérgio, é redução progressiva à interioridade do espírito, o combate constante ao separatismo espontâneo, a afirmação permanente da totalidade e do Uno. «Do todo e do uno - diz - é que o racionalista zarpa, e ao todo e ao uno é que o racionalista aporta; parte do infinito e ao infinito chega» (194). Para tudo dizer de um golpe, na base como no topo, a recíproca sustentação das ideias radicada num aprioristico dever-ser inteligível.

Para o historiógrafo idealista que é Sérgio, a inteligibilidade histórica, como toda a inteligibilidade, assenta no postulado básico da investigação científica. A saber: o postulado da universal inteligibilidade. Postulado que, no seu entender, é necessariamente de teor extra-científico.

No idealimo «sérgico» (como por vezes dizia), sobreleva a sua coerência sistemática - a despeito da suposta ou real relutância de Sérgio por tudo o que se aparenta a um sistema. O facto, não obstante, é que Sérgio sempre buscou, e com perfeita consciência de isso, um sistema de pensar coerente, intrinsecamente coeso, estruturante e englobante, num orientado impulso de reflexão congruente, de concatenação efectiva. $\mathrm{O}$ seu escopo último foi sempre visar, em todas as circunstâncias e nos mais variados domínios, «a máxima coerência numa concepção amplíssima» ${ }^{(195)}$. Ele sempre foi em tudo o constante buscador de «o todo uno» - para usar de uma expressão sua que tanto lhe comprazia. «A consciência da construção e da harmonia» (são ainda palavras suas a um

(193) «Livros e Periódicos», Seara Nova, XVIII, n. ${ }^{\circ}$ 599, 1939, pp. 350-351.

(m) «Razão e poesia, razão e mística», Seara Nova, XI, n. ${ }^{\circ}$ 286, 1932, p. 252; Cf. Ensaios, III, Renascença Portuguesa, 1932, pp. 389-391.

(195> Prefácio do Tradutor a Berkeley. Três Diálogos entre Hilas e Filonous em Oposição aos Céticos e Ateus. Tradução, Prefácio e Notas de António Sérgio, Atlântida, Coimbra, 1948, p. XXXVIII. 


\section{Antonio Sérgio}

outro propósito) dominam a sua doutrinação de ponta a ponta. Assim significava Sérgio, exprimindo de passo a universalidade do seu espírito, a sua permanente preocupação pelo «universalismo integrante da sua visão das coisas» (198). Sérgio tem, pois, concludentemente, e outrossim no particular domínio da História - e neste ponto num espírito em perfeita consonância com a mais recente e mais válida historiagrafia, - uma concepção totalizante, onde tudo se relaciona e conjuga. E neste sentido, como em tantos outros (v. g. a sua total rejeição da obsoleta tradição positivista e empirista), a sua obra do ponto de vista historiográfico, situa-se obviamente para além da crise do historismo tradicional.

Para Sérgio, ávido de racionalidade em tudo - sempre a razão na base de tudo, raiz de tudo, é seu lema constante - a sua indagação histórica, ainda quando é só, aparentemente, histórica, quando o intuito das suas análises incide tão-somente sobre pontos concretos de história, radica numa ideação filosófica (197). Na verdade, toda a actividade histórica, ou histórico-sociológica, digamos assim, se prende coerentemente e propositalmente, no pensamento de Sérgio, aos pressupostos filosóficos que norteiam toda a sua ideação. Reflexão filosófica, pois, sempre na base de todos os seus escritos, formulada ou tácita. Escritos ensaísticos de crítica literária, de moral, de política, de sociologia, de economia social, de pedagogia, de história também, é evidente; e, como diz, se nem sempre merecem a designação de «filosóficos», quem

(198) «Viana da Mota: Sobre o universalismo integrante da sua visão das coisas», Viana da Mota. In Memoriam, Lisboa, s.d. [1952]. Gf. «Sobre a universalidade do espírito de Viana da Mota», Ensaios, VIII, Europa-América, Lisboa, 1954, pp. 127-133.

(19T) Recorde-se, por exemplo, um facto pouco conhecido. Ao ter sido certa vez acusado malevolamente de haver plagiado de um opúsculo de Rudolf Carnap, de 1933, a sua crítica da lògica do juízo de predicação, Sérgio fez oportunamente salientar «Em Torno de um complicado caso de consciência», Seara Nova, XVIII, n. ${ }^{\circ} 543,1938$, p. 339; cf. «Factos e Documentos», Seara Nova, XVII, n. ${ }^{\circ}$ 15, 1937, esp. p. 217) que, não só nunca pretendeu ser essa uma ideia original sua, antes correntissima na lógica moderna e advogada muito antes de Carnap designadamente por Bertrand Russell, mas que, ademais de isso, como é do conhecimento de seus leitores que o têm lido com inteligência, a sua rejeição da lògica aristotélica do juízo de predicação, e, ao invés, a sua afirmação correlativa que, para o racionalismo que ele concebe, o juízo essencial é o juízo de relação, não o predicativo, ideias subjacentes já nas doutrinas dos primeiros ensaios que publicou, e bem assim nomeadamente no artigo «Razão e poesia, razão e mística», Seara Nova, XI, n. ${ }^{\circ} 286,1932$, esp. pp. 352-353; n. ${ }^{\circ} 289$, 1932, pp. 5 e $9 ;=$ Ensaios, III, Renascença Portuguesa, Porto, 1932, pp. 389-392, 401, 408-409, «acha-se até implícita na minha maneira de conceber a Histó- 
quer que os leia com um olhar agudo achará que pressupõem uma reflexão filosófica, onde existe implícito- e algumas vezes explícito - o principal do que propõe nos seus textos de aclarações propriamente filosóficas e que visam incitar directamente a actividade de crítica reflexão filosófica, como testemunham claramente as suas Cartas de Problemática [epistemológica]. "Tudo isto, porém, sobre uma base de reflexão filosófica» (198).

Por isso que «o intelecto é uno» - como era seu hábito afirmar (199) —as suas análises sobre pontos vários e díspares de história, traduzem e evidenciam sempre, para o leitor atento e vigilante, a integração num estruturado, sistematizado, corpo de ideias. As suas «heresias» históricas são, no fundo, afins das suas «heresias» epistemológicas $\left({ }^{20}\right)$.

É esta uma ideia que tem de estar em permanência presente no espírito de quem o lê, se realmente o quer entender a primor. É esta uma ideia sobrepairante a todos os seus escritos, ideia a que todas as ideias e reflexões de Sérgio abicam, seja qual for o domínio considerado, e onde todas se entroncam.

Ele o disse claramente referindo-se à história, e não só a ela, mas fitando um horizonte mais vasto: "Ao que supomos, a civilização humana é um fenómeno uno, que se difundiu a partir de determinada zona: e tentar narrar de maneira inteligível as actividades de um povo civilizado qualquer é buscar introduzi-las nesse todo uno, de maneira que se per-

ria, onde as ideias gerais são substituidas pela relacionação particular de cada parte com o todo.» $E$ acrescenta: «Mas para ver isso é preciso pensar e ler-se com inteligência, coisa que só posso esperar de um número restrito de leitores» (Seara Nova, XVIII, n. ${ }^{\circ} 543,1938$, p. 339). Para ver isso, claro está, e o mais que há de propriamente filosófico na sua maneira peculiar de conceber a história. Outra ocasião ainda, que nos recorde, volta ao tema. Após ter escrito: «Desde que o acto de conhecer uma coisa não é passar para uma ideia geral (quer dizer: para a ideia da classe a que a coisa pertence), mas sim apreender as relações com o todo que veem entrelaçar-se no objecto dado - existe o conhecimento do particular, contra o que pensava esse mesmo Aristóteles....", Sérgio remata: "E isto doutrina que eu aplico a tudo, sem distinguir disciplinas. Seria fácil verificar que a minha História de Portugal (da coleç̧ão Labor, Barcelona) foi toda ela construída segundo as ideias que the exponho aqui». ("Resposta a uma consulta», Seara Nova, XV, n. 466, 1936, p. 156; ef. Seara Nova, XVIII, n. $.^{\circ} 44,1938$, p. 366).

$\left.{ }^{(1 \mathrm{~B} 8}\right)$ Cartas de Problemática, carta n..$^{\circ}$, ed. Inquérito, Lisboa, 1952, pp. 6 e 8.

(ii) Por ex.: Ensaios, IV, Lisboa, 1934, p. 257.

i“") Ver: «Nota sumária sobre as minhas «heresias» epistemo-

lógicas», Lusíada, I, n. ${ }^{\circ}$ 1, Porto, 1952, pp. 18-19. Separata, pp. 1-2. 
ceba como é parte do todo. Ganhar o entendimento de qualquer fenómeno significa descobrir as relações inteligíveis dos vários elementos que o constituem, bem como as relações inteligíveis dele com um todo imediato de que faz parte, o qual por sua vez relacionamos com outro, mais inclusivo do que aquele primeiro; e assim por diante. A realidade é a conexão de tudo com tudo, numa cadeia infinita de acções recíprocas; e somente o Todo é que existe por si». E ainda, para que bem entendam os seus propósitos: «Ao pretender interpretar os eventos humanos de que tratam os historiadores propriamente ditos, é na trama de relações de cada um dos mesmos (e portanto por uma forma essencialmente histórica, onde se busca a ciência do caso particular) que eu tento a explicação e interpretação dos factos, e não no império de uma «ideia geral»,- como seja a da preeminência da estrutura económica, ou então a do ambiente exclusivamente geográfico, concebidos como determinantes de tudo mais. O que constitui o ambiente de uma sociedade humana pode ser uma teia infinitamente complexa, - e quanto mais adiantadas as sociedades são, menos sujeitáveis a uma fórmula geral. Não é na subsunção a um conceito genérico que suponho residir a explicação dos sucessos. Cada um explica-se pelos seus próprios factores, entre os quais o intelecto e a vontade do homem, capazes de reagir sobre o ambiente em que ele vive» $\left({ }^{201}\right)$.

Assim pois, a sua reflexão histórica assenta, logicamente, numa reflexão filosófica.

Destarte, toda a sua ideação histórico-social é idealista. E idealista estrita, radical, de extremo a extremo. Na verdade, o seu «idealismo epistemológico», «idealismo epistemológico, racional e crítico» (como precisou), está por inteiro na sua maneira de conceber a história. As relações entre o idealismo histórico-social e $\quad$ o idealismo epistemológico são recíprocas; entrelaçam-se (como diria Sérgio) numa coroa de acções recíprocas, como partes de um todo em relação recíproca. A esse todo, racionalista de cariz idealista, quadra a preceito a designação de idealismo crítico. São pois nomes diversos (202) de uma coisa só, de uma só postura mental: a que é própria de António Sérgio e lhe confere um lugar único nas nossas letras.

(so1) «Em Torno da 'História Trágico-Marítima'», Ensaios, VIII, Guimarães Editora, Lisboa, 1958, pp. 93-94.

$C^{202}$ ) Sobre este ponto, ver, v.g., Ensaios, VII, Europa-América, Lisboa, 1954, pp. 235, 261-263. 